\title{
EFEITOS DA ADUBAÇĀO FOSFATADA E DA DENSIDADE DE PLANTAS NA PRODUÇÃO E QUALIDADE DAS SEMENTES OBTIDAS EM QUATRO CULTIVARES DE FEIJÃO (Phaseolus oulgaris L.)
}

\author{
MARCO EUSTÁQUIO DE SÂ \\ Engenheiro Agrônomo
}

Orientador: Prof. Dr. EUJANDIR WILSON DE LIMA ORSI

Dissertação apresentada à Escola Superior de Agricultura "Luiz de Queiroz", da Universidade de São Paulo, para obtenção do título de Mestre em Fitotecnia.

$P$ IR A C ICAB A

Estado de São Paulo - Brasil

Abril, 1982 
A família, como o símbolo

de união dos povos,

DEDICO .

A minha esposa,

Adelaide,

OFEREÇO. 


\section{N D I C E}

pāgina

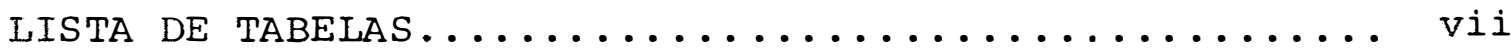

RESUMO ............................

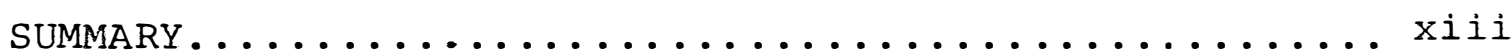

1. INTRODUÇÃO .......................... 1

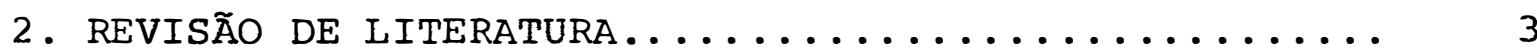

2.1. Cultivares e époças de semeadura............ 4

2.2. Adubação fosfatada..................... 7

2.3. Densidade de plantas.................... 16

2.4. Métodos de análise e qualidade das sementes... 20

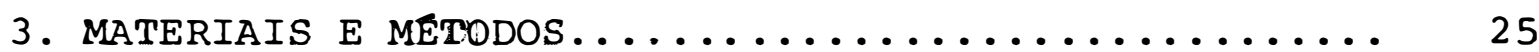

3.1. Local de ensaio...................... 25

3.1.1. Características do local........... 25

3.2. Adubação.......................... 27

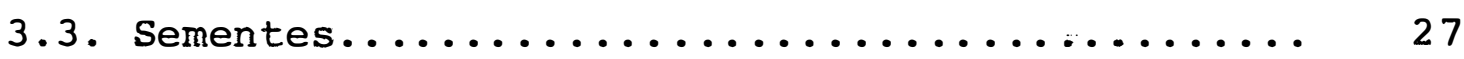

3.4. Delineamento experimental............... 28

3.4.1. Tamanho das parcelas............... 29

3.4.2. Area do experimento.............. 30

3.5. Semeadura.......................... 30

3.6. Tratos culturais...................... 30

3.6.1. Desbaste.................... 30

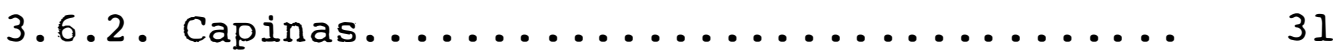

3.6.3. Controle de pragas e moléstias........ 31 
Pāgina

4.8. Envelhecimento rápido.............. 73

4.9. Velocidade de germinação.............. 76

4.10. Teor de proteína nas sementes............. 80

4.11. Teor de fósforo nas sementes.............. 85

4.12 . Aspectos gerais..................... 88

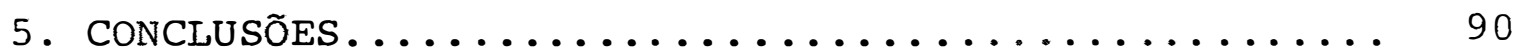

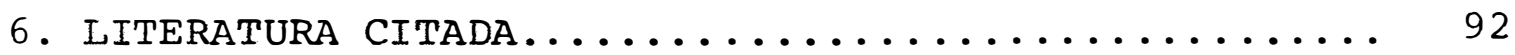

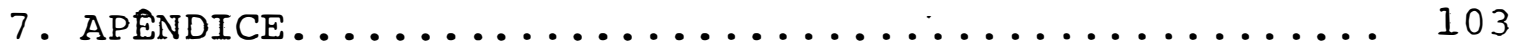


10 Produção de sementes $(\mathrm{kg} / \mathrm{ha})$. Médias obtị das para as quatro cultivares, doses de fósforo e densidades. Ilha Solteira, 1981..

11 Peso de mil sementes (g). Análise da va riância dos dados obtidos............

12 Peso de mil sementes (g). Médias obtidas para diferentes cultivares, doses de fósforo e densidades. Ilha Solteira, 1981...

13 Porcentagem de germinação. Análise da va-i riância dos dados obtidos.............

14 Porcentagem de germinação. Médias obtidas para as doses de fósforo em relação às quatro cultivares e densidades. Ilha Sol-

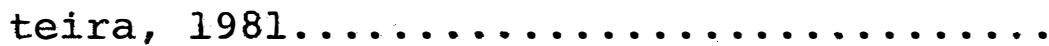

15 Porcentagem de germinação de sementes de 4 cultivares de feijão cultivadas em três doses de adubação fosfatada e 2 densida des de plantas (dados transformados em arc sen $\left.\sqrt{\frac{g}{6} / 100}\right)$. Ilha Solteira, 1982...

16 Indice de vigor: primeira contagem do testeste de germinação. Análise da variância dos dados obti dos (dados transformados em arc sen $\sqrt{8 / 100}$ ) .... 
24 Teor de proteina nas sementes. Anālise da variância dos dados obtidos (dados transformados em arc

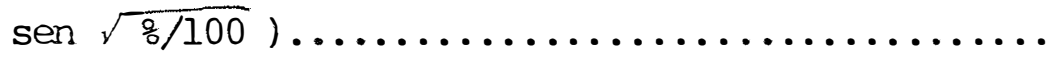

25 Teor de proteína nas sementes. Médias obtidas para diferentes cultivares, doses de fósforo e densidades (dados transforma dos em arc sen $\left.\sqrt{\frac{0}{8} / 100}\right)$. Ilha Solteira,1981

26 Teor de fósforo nas sementes. Análise da variância dos dados obtidos............

27 Teor de fósforo nas sementes. Médias obtí das para diferentes cultivares e doses de fósforo e densidades. Ilha Solteira,1981. 


\section{EFEITOS DA ADUBAÇÃO FOSFATADA E DA DENSIDADE DE PLANTAS NA PRODUÇ,̃OO E QUALIDADE DAS SEMENTES OBTIDAS EM QUATRO CULTIVARES DE FEIJÃO (phaseolus vulgaris L.)}

Autor: MARCO EUSTAQUIO DE SA

Orientador: PROF. DR. EUJANDIR W. LIMA ORSI

\section{RESUMO}

No campo experimental da UNESP, Campus de Ilha Solteira, localizado em áreas de solo sob vegetação de cerrado, no município de Selvíria, Estado de Mato Grosso do Sul, foi realizado um experimento com a finalidade de estudar os $\underline{e}$ feitos de três doses de fósforo e duas densidades de plantas sobre a produção e qualidade das sementes obtidas em quatro cultivares de feijão (Phaselus vulgaris L.).

Foi utilizado um arranjo fatorial $4 \times 3 \times 2$, com os tratamentos sendo distribuídos em blocos ao acaso com 4 re petições.

Os níveis de fósforo foram $0 \mathrm{~kg}, 75 \mathrm{~kg}$ e 150 $\mathrm{kg}$ de $\mathrm{P}_{2} \mathrm{O}_{5} / \mathrm{ha}$, enquanto que as densidades foram de $200.000 \mathrm{e}$ 300.000 plantas/ha, e as quatro cultivares utilizadas foram: Carioca, Rico 23, Bolinha e Goiano Precoce.

Foram avaliados os seguintes parâmetros: altu- 
ra de plantas, número de vagens por planta, números de grãos por vagem, produção de sementes em $\mathrm{kg} / \mathrm{ha}$, peso de $\mathrm{mil}$ semen tes, porcentagem de germinação, vigor (velocidade de germinação, primeira contagem de germinação, envelhecimento rápido), teor de proteína nas sementes e teor de fósforo nas sementes. Após as anālises dos dados obtidos pôde-se con cluir que:

- As cultivares responderam diferentemente à adubação fosfata da e à densidade de plantas.

- A altura das plantas, número de vagens por planta e produção de sementes aumentaram substancialmente com a dose de fertilização fosfatada.

- Em relação à produção de sementes, para todas as cultivares os melhores resultados foram obtidos com $150 \mathrm{~kg} / \mathrm{ha}$ de $\mathrm{P}_{2} \mathrm{O}_{5}$ e $300.000 \mathrm{plantas} / \mathrm{ha}$.

- A cultivar Carioca apresentou-se como a mais produtiva.

- A densidade de plantas afetou a produção de sementes das cultivares porém não afetou a qualidade das mesmas.

- A fertilização fosfatada afetou o peso de mil sementes das cultivares Goiano Precoce, Carioca e Rico 23 porém não afetou o peso de mil sementes da cultivar Bolinha. 


\section{EFFECT OF PHOSPHATE APPLICATION AND I NUMBER OF PLANTS PER HECTARE ON YIELD AND QUALITY OF THE SEEDS FROM FOUR BEAN VARIETIES (Phaseolus vulgaris $L$, )}

Author: MARCO EUSTÅQUIO DE SA

Adviser: PROF. DR. EUJANDIR W. LIMA ORSI

SUMMARY

An: experiment was carried out on the experimental field of UNESP, Ilha Solteira Campus. This field is an area under "cerrado" type vegetation and is located in the Selviria municipality State of Mato Grosso do Sul. The main objective was to study the effect of 3 rates of phosphate and two plants densities on the yield and quality of the seeds obtained from four bean varieties (Phaselus vulgaris L.).

A $4 \times 3 \times 2$ factorial design was utilized. The treatment were distributed in random blocks with four replications. The rates of phosphate applied were $0 \mathrm{~kg}, 75 \mathrm{~kg}$ and $150 \mathrm{~kg}$ of $\mathrm{P}_{2} \mathrm{O}_{5} / \mathrm{ha}$ and plants densities were 200,000 and 300,000 plants/hectare. The four varieties used were "Carioca", "Rico 23", "Bolinha" and "Goiano Precoce".

The following parameters were evaluated: plant height, number of pods per plant, number of seeds per pod, 
yield of seeds in $\mathrm{kg} / \mathrm{ha}$, weight of 1,000 seeds, $\frac{8}{0}$ germination, vigor (velocity of germination, first germination coumt, accelerated aging), seed protein content and seed phosphorus content. The analysis of the results led to the following

conclusions:

- The varieties showed different response to phosphate application and plant density.

- Plant height, number of pods per plant and seed production increases with the rate of phosphate application.

- Highest yields for all varieties was obtained with 300,000 plants/ha and $150 \mathrm{~kg} / \mathrm{ha}$ of $\mathrm{P}_{2} \mathrm{O}_{5}$.

- Carioca variety performed better than other as to yield.

- Rate phosphate application did influence the weight of 1,000 seeds of the Goiano Precoce, Carioca and Rico 23 varieties, but it did not affected the weight of a 1,000 seeds the Bolinha variety. 


\section{INTRODUÇÃO}

o feijão (Phaseolus vulgaris L.) é um dos produtos agrícolas da mais alta expressão econômica e social, constituindo-se juntamente com o arroz a base da alimentação do povo brasileiro, sendo para diversas classes a principal fonte protéica.

No entanto, apesar da grande importância da cultura, tem-se verificado um decréscimo na sua produtivida de, IEA (1981). Isto, tem levado o país a recorrer à importação para suprir a demanda interna, fator este bastante negati vo, se levarmos em consideração que nas condições brasileiras pode-se lançar mão de diversas alternativas para enfrentar os problemas que afetam esta cultura.

Diversas são as dificuldades encontradas no cul tivo do feijoeiro no Brasil, sendo que algumas delas destaca das pela EMBRAPA (1978) foram: pequena utilização de sementes 
selecionadas, não emprego de fertilizantes, espaçamentos inadequados, variedades suscetíveis a doenças e pragas e de baixo rendimento, solos de baixa fertilidade natural, etc.

Outro problema bastante recente e que vem alar mando os nossos agricultores é a escassez e o esgotamento das áreas mais férteis que estão quase em sua totalidade ocupadas por culturas altamente mecanizáveis. Estes fatos têm levado pesquisadores e agricultores a explorarem novas áreas, princi palmente as de solo sob vegetação de cerrado. Sabe-se, no entanto, que estas áreas apresen tam certas limitações com respeito a deficiências hídricas e fertilidade natural, principalmente deficiência de fósforo.

Em face a todos estes problemas, no presente estudo, objetivou-se verificar o efeito de três níveis de adu bação fosfatada e de duas densidades de plantas, na produção e qualidade das sementes de quatro cultivares de feijão, cultivadas num solo sob vegetação de cerrado, utilizando-se irri gação por aspersão no período de inverno. 


\title{
2. REVISÃO DE LITERATURA
}

\begin{abstract}
A literatura com respeito a cultura do feijoe $\underline{\mathbf{i}}$ ro apresenta diversos trabalhos, havendo um bom nümero nas con dições brasileiras. No entanto, este nümero é ainda insuficiente, sendo que a falta de pesquisas nessa área é citada co mo um dos empecilhos que dificultam o desenvolvimento da cultura. Pode-se ressaltar, porém, que nos ūltimos anos, a cultụ ra do feijoeiro vem recebendo uma maior atenção dos organismos governamentais, devido aos problemas alarmantes que a mes ma tem sofrido, fator este que fez com que houvesse um maior investimento na pesquisa do feijoeiro no país.
\end{abstract}




\title{
2.1. Cultivares e Épocas de semeadura
}

\begin{abstract}
Diversas são as cultivares utilizadas nas mais diversas regiões brasileiras. No entanto, pela produtividade, resistência a pragas e moléstias, preferência popular e facilidade de comercialização, algumas têm se destacado em quase a totalidade dos locais.
\end{abstract}

ALMEIDA et alii (1971) analisando as principais cultivares de feijão utilizadas no Estado de são Paulo des tacaram como as principais: Bico-de-Ouro, Carioca, Rosinha G-2, Chumbinho Opaco, Goiano Precoce, Pintado e Preto G-1. Recomenda ções da Comissão Nacional de Feijão, conforme VIEIRA et alii (1972) indicavam as seguintés cultivares para o Estado de são Paulo: Carioca, Rosinha G-2, Bico-de-Ouro, Goiano Precoce e Piratã 1 .

Trabalhos de CUNHA et alii (1975) na Estação Experimental de Patos de Minas verificaram como mais produtivas as cultivares Rico 23, Costa Rica, Venezuela 350, Iguaçu, Carioca, Jalo e Guatemala 344, devendo serem recomendadas naquela região.

ALMEIDA et alii (1977) em ensaios de competição de cultivares de feijoeiro em Mococa e Monte Alegre doSul, através da média de oito experiências, obtiveram que a cultivar Carioca apresentou produção significativamente superior às demais, ficando as cultivares Pintado, Chumbinho Opaco e Rico 23 num grupo intermediário e as cultivares Bico-de-Ouro, 
Preto G-1 e Rosinha G-2 se apresentaram como as menos produti vas. Também NAKAGAWA et alii (1978), estudando o comportamento de diversas cultivares de feijão na região de são Manoel-SP, constataram que as cultivares Piratã e Goiano Precoce fo ram as que sobressairram, enquanto que a cultivar Rosinha G-2, apresentou menor produção.

Em listagem das principais cultivares tradicio nais e melhoradas, cultivadas nos estados brasileiros, GUAZZELLI (1980) relaciona para são Paulo as seguintes cultivares tra dicionais: Mulatinho, Bico-de-Ouro, Chumbinho, Raxinho, Jalo, Goiano Precoce e Rosinha; e as seguintes melhoradas: Carioca, Piratã 1 e 2, Aroana, Moruna, Aeté e Rosinha G-2. Conforme o autor, as cultivares Incluídas apresentam reconhecidas qualidades comerciais, além de terem se comportado bem em ensaios de rendimento, muito embora algumas delas ainda não tivessem sendo cultivadas extensivamente.

Em indicações de cultivares para cultivo de feijão no inverno SARTORATO et alii (1981) listam as seguin tes cultivares de ciclo normal (90-100 dias): Carioca, Rio Tibagi, Rico 23, Jalo EEP558, Rico Baio, IPA7419, Costa Rica e Roxão EEP, e de ciclo curto (60-70 dias): CNF0010, Goiano Pren coce e Palmital Precoce. Segundo estes autores, estas cultiva res têm-se mostrado produtivas em cultivos nas épocas tradi cionais, sendo que a produtividade delas em cultivo de inverno têm oscilado entre 1.500 e $3.000 \mathrm{~kg} / \mathrm{ha}$ em campos de multiplicação de sementes. 
Trabalhos recentes sobre cultivares em diversos locais do Brasil têm mostrado um comportamento bastante bom principalmente da cultivar Carioca. CosTA (1982) em Barreiras-BA, em ensaio de avaliação regional de cultivares de feijão, conduzido sob regime de irrigação, obteve as melhores produções para as cultivares Carioca (1.626 kg/ha) , IPA-l (1.552 kg/ha) e IPA-7419 (1.483 kg/ha), apresentando ren dimentos de 45,83\%, 38,57\% e 32,41\%, respectivamente, supe riores à testemunha Mulatinho Vagem Roxa (1.120 kg/ha). Também ALMEIDA et alii (1982) apresentando resultados de quatro anos de experiências com cultivares e linhagens de feijão na região Noroeste do Estado de São Paulo, mostraram que dentre as cultivares destacaram-se H $38 \mathrm{Cl} 727$ (Catu), H 40Cl725 (Moruna) e H 40Cl722 (Aroana) dentre outras. Ainda trabalhos de ALMEIDA et alii (1982b) comparando o comportamento de cultivares e li nhagens na região sudoeste do Estado de são Paulo, durante os anos de 1973 a 1977, observaram que as linhagens Moruna, Aroa na, Catu e Aeté-3, foram as que melhor se comportaram em todos os experimentos, enquanto que a cultivar Carioca, atual mente a mais cultivada em todo o Estado mostrou uma boa produtividade, mas se colocando no grupo intermediārio dentre os 21 materiais testados.

Com relação à época de semeadura, tradicionalmente, a cultura do feijoeiro tem sido cultivada nas mais diversas regiões do paîs em duas épocas:a época das "águas" de outubro a dezembro e na época das "secas" de janeiro a março, 
com algumas exceções. No entanto, nas āreas em que o inverno não é rigoroso é possível outra safra de feijão caso o produtor utilize irrigação, VIEIRA (1978), SARTORATO et alii (1981), SILVEIRA et alii (1981), com a semeadura sendo efetuada de abril a fins de junho.

De acordo com SARTORATO et alii (1981) o culti vo de feijão no inverno possibilita inümeras vantagens como: obtenção de produtividades mais altas $(1,5$ a 3 t/ha); maior es tabilidade de produção devido à menor dependência dos fatores climáticos; possibilidade da oferta do produto na entressafra facilitando a solução do problema de armazenagem e qualidade; expansão da área da cultura sem competição com produtos de ex portação, como a soja e o milho; oferece condições excepcio nais para a produção de sementes.

\subsection{AduBAÇÃO FOSFATADA}

* fósforo é o componente básico das nucleoproteínas, ácidos nucléicos (DNA, RNA), fosfolipídeos e enzimas, envolvidas no transporte de energia. Além disso, atua nas rea ções de fosforilação, fotossíntese, respiração, síntese e decomposição de carboidratos e proteínas. Todos esses processos afetam o crescimento radicular, a floração e maturação de fru tos nas plantas. Conforme VIEIRA (1978), embora o fósforo seja exigido em pequena quantidade pelo feijoeiro, constitui-se no macronutriente que tem proporcionado os melhores resulta- 
dos na adubação, o que pode ser explicado pela sua pobreza em nossos solos. Fato este, também ratificado por GUAZZELLI et alii (1973) que relatam ser a deficiência de fósforo um fator limitante na produção do feijoeiro em muitas áreas do Brasil, principalmente nas de solo sob vegetação de cerrado.

Diversos trabalhos têm sido realizados comfins de se verificar a resposta da cultura ao fósforo e qual a fon te mais adequada para fornecê-lo.

MIYASAKA et alii (1965) estudaram o efeito da adubação verde, calagem e adubação mineral do feijoeiro em so lo sob vegetação de "cerrado" e concluíram que o efeito da adubação verde sobre a produção do feijoeiro foi de apenas $\pm 13 \%$ na presença de NPK e negativo na ausência dessa adubação; a presença da adubação mineral favoreceu consideravelmente a resposta à calagem; o efeito residual do fósforo correspondeu à $\pm 123 \%$.

MASCARENHAS et alii (1967) estudaram em solos sob vegetação de cerrados recém-desbravados, no Planalto Paulista, os efeitos de NPK e calcārio. Observaram que a calagem e a adubação fosfatada utilizadas somente no primeiro ano foram fatores que mais influíram na produção do feijoeiro. obti veram ainda as maiores respostas para os tratamentos em que se associaram o calcário e o fósforo.

Realizando uma série de quatro ensaios em Pira cicaba, GODOY (1968) observou resposta significativa ao fósforo. Conforme o autor, o fósforo garantiu colheitas economica- 
mente compensadoras, sendo $63 \mathrm{~kg}$ de $\mathrm{P}_{2} \mathrm{O}_{5}$ a dose aconselhável para dar uma produção de $1.500 \mathrm{~kg} / \mathrm{ha}$.

BRAGA (1969) estudando o efeito de diferentes fosfatos aplicados na cultura do feijoeiro concluiu que há resposta muito boa ao uso de fosfato diamônico seguindo-se fa rinha de ossos, termofosfato e fosfato de Araxá.

Trabalhos de COBRA NETO et alii (1971) em 177

ensaios visando o estudo da nutrição mineral do feijoeiro, vạ riedade Roxinho, em diversos Estados brasileiros, mostraram que a produção de matéria seca foi afetada pelos tratamentos na seguinte ordem decrescente: $S, K, \mathrm{Mg}, \mathrm{Ca}, \mathrm{P}$ e $\mathrm{N}$, e que os elementos mais absorvidos pela cultura seguiram a seguinte or dem decrescente: $\mathrm{N}, \mathrm{K}, \mathrm{Ca}, \mathrm{S}, \mathrm{Mg}$ e P.

Estudando o efeito do fósforo na nodulação e produção do feijoeiro, ALMEIDA et alii (1973) verificaram que o fósforo nas dosagens de $80 \mathrm{~kg}$ e $160 \mathrm{~kg}$ de $\mathrm{P}_{2} \mathrm{O}_{5} / \mathrm{ha}$ causaram um aumento de produção na ordem de $36,3 \%$ e 35,1\%, respectivamente, com relação à testemunha. A aplicação de fósforo e cal cário aumentou o peso dos nódulos, mas no entanto, este aumen to não foi correlacionado à produção. Os autores observaram ainda que somente o fósforo teve efeito significativo sobre o peso das plantas colhidas na época de florescimento.

Trabalhos de EIRA et alii (1973), comparando es quemas experimentais em experimentos de adubação mineral de nitrogênio e fósforo na cultura do feijoeiro, observaram que a cultura reagiu favoravelmente à adubação fosfatada ocorren- 
do efeito significativo, enquanto que para $\mathrm{N}$ em nenhuma das a nālises se observou significância.

FONTES et alii (1973) analisando a resposta da cultura do feijão à aplicação de calcário, adubo nitrogenado e fosfatado em Municípios da Zona da Mata, MG, observaram que houve efeito diferencial dos tratamentos sobre o feijoeiro , em função do local e da estação de plantio. No primeiro plantio em Viçosa, as três variāveis aumentaram significativamente a produção de grãos. O nitrogênio foi o fator mais impor tante, seguido do fósforo e do calcário.

Trabalhos de EIRA et alii (1974) visaram verificar os efeitos da adubação mineral de fósforo e potássio na cultura do feijão no período das secas e o efeito residual no período das águas, em solo aluvial, no Estado do Rio de Janei ro. Foi utilizado um fatorial completo $5 \times 5$ sendo que os cinco níveis de fósforo foram: $0 \mathrm{~kg}, 60 \mathrm{~kg}, 120 \mathrm{~kg}, 180 \mathrm{~kg}$ e $240 \mathrm{~kg} /$ /ha de $\mathrm{P}_{2} \mathrm{O}_{5}$. Utilizou-se a cultivar Rico 23 nos dois experi mentos. Os autores observaram, no primeiro experimento, efeito significativo para fósforo, sendo que $79 \mathrm{~kg} / \mathrm{ha}$ de $\mathrm{P}_{2} \mathrm{O}_{5}$ foi tida como a dose ótima, enquanto que a dose econômica foi de $55 \mathrm{~kg} / \mathrm{ha}$ de $\mathrm{P}_{2} \mathrm{O}_{5}$. No segundo experimento para se constatar o efeito residual, não se verificou reação ao fósforo, conforme foi mencionado pelos autores.

Em estudos realizados por KORNELIUS et alii (1975) visando verificar os efeitos de doses de nitrogênio e fósforo na cultura do feijão, os autores concluíram que a do- 
se de $50 \mathrm{~kg} / \mathrm{ha}$ de $\mathrm{P}_{2} \mathrm{O}_{5}$ foi a que apresentou melhores resultados apesar que doses maiores apresentaram maiores produções , porém, não significativas.

KRANZ et alii (1976) em ensaio de adubação e calagem do feijoeiro, estudaram as respostas da cultura a N, $\mathrm{P}_{2} \mathrm{O}_{5}$ e $\mathrm{K}_{2} \mathrm{O}$ em solos do Paraná em dois ciclos da cultura. Concluíram que os resultados obtidos, indicaram não haver respos ta significativa a $\mathrm{N}$ nas condições do ensaio. No entanto, o fósforo quase sempre mostrou efeito linear com aumentos de 30 a 55\% na safra das águas e de 42 a 78\% na safra das secas, a partir da dose de $40 \mathrm{~kg}$ de $\mathrm{P}_{2} \mathrm{O}_{5} / \mathrm{ha}$. O $\mathrm{K}$ aplicado não apresentou respostas significativas em nenhuma das épocas ou locais onde os ensaios foram instalados.

PARODI et alii (1977) estudando efeitos da aplicação de fósforo sobre o rendimento e conteúdos de $\mathrm{N}$, P e K na planta de feijão observaram que as aplicações de $\mathrm{P}$ eleva ram os teores destes elementos nos solos e na planta, mas não se traduziu num aumento de matéria seca. Os conteúdos de $\mathrm{N}$ e $\mathrm{K}$ nas plantas não foram afetados pelas aplicações de $\mathrm{P}$.

Estudos realizados por VEIGA et alii (1977) ví sando observar o efeito da incorporação de massa verde de Cro talaria juncea L., da calagem e da adubação mineral com nitro gênio e fósforo sobre a produção do feijoeiro mostraram que os efeitos de $\mathrm{N}$ e $\mathrm{P}$, quando existentes, foram predominantemen te lineares e, em sentido inverso, um em relação ao outro. Se gundo os autores, os tratamentos de adubação mineral, compor- 
tam-se de maneira complexa dentro de cada tratamento aplicado às parcelas, sendo observadas poucas interações entre o nitro gênio e o fósforo.

GUEDES e JUNQUEIRA NETO (1978) relatam que nos solos sob cerrado onde os problemas de disponibilidade de fós foro são mais acentuados o sucesso do feijoeiro está quase que exclusivamente na dependência de uma correta adubação fosfata da. A deficiência de fósforo afeta principalmente o desenvolvimento geral da planta, que apresenta pouca ramificação com reflexos altamente negativos na produção. Segundo estes autores, nos solos sob vegetação de cerrado, alēm da calagem, deve-se fazer uma adubação corretiva, que consiste na incorpora ção, juntamente com o calcário, de uma tonelada de fosfato natural.

Estudos para se verificar os efeitos da adubação mineral na cultura do feijoeiro no período de inverno, no Vale do Paraíba-SP, durante os anos de 1977, 78 e 79, foram feitos por ALMEIDA et alii (1982). Dentre os tratamentos, foram testadas três doses de fósforo $\left(30,60\right.$ e $90 \mathrm{~kg} / \mathrm{ha}$ de $\left.\mathrm{P}_{2} \mathrm{O}_{5}\right)$. Segundo os autores, nos três anos de experimentação, os resul tados mostraram, para os três locais em que se realizaram os ensaios, que de um modo geral, a utilização isolada da calagem, de fósforo ou da mistura desses elementos, não foi suficiente para provocar aumentos na produção.

Conforme BERGER et alii (1982), estudos realizados na Zona da Mata-MG, têm mostrado que a cultura do fei- 
jão pode responder a doses tão altas como $260 \mathrm{~kg} / \mathrm{ha}$ de $\mathrm{P}_{2} \mathrm{O}_{5} \mathrm{e}$ $150 \mathrm{~kg} / \mathrm{ha}$ de $\mathrm{N}$. Em experimento realizado por estes autores utilizou-se combinação das doses de N (0, 30, 60, 90 e $120 \mathrm{~kg} /$ /ha) com doses de $\mathrm{P}_{2} \mathrm{O}_{5}(0,60,120,180$ e $240 \mathrm{~kg} / \mathrm{ha})$. A culti var utilizada foi Negrito 897, numa densidade de 15 a 17 sementes por metro linear. Conforme os autores, na ausência de $\mathrm{N}$ o efeito do $\mathrm{P}$ foi linear. Com as outras doses de $\mathrm{N}$ o efeito do $P$ foi sempre quadrático, sendo que com uma dose de $120 \mathrm{~kg} /$ /ha de $\mathrm{N}$ e $167 \mathrm{~kg} / \mathrm{ha}$ de $\mathrm{P}_{2} \mathrm{O}_{5}$ a produção de grãos atingiu 2.500 $\mathrm{kg} / \mathrm{ha}$.

Trabalhos de BULISANI et alie (1982), em Campi nas e Monte Alegre do Sul-SP, visaram verificar a resposta de cinco cultivares de feijão a níveis crescentes de $\mathrm{N}, \mathrm{P}_{2} \mathrm{O}_{5}$ e $\mathrm{K}_{2} \mathrm{O}$ em dois anos e dois ciclos consecutivos "águas" e "secas". As cultivares testadas foram: Bico-de-Ouro, Carioca, Roxão, Rico 23 e Rosinha G-2, enquanto que os níveis de fósforo testados foram $0,40,80$ e $120 \mathrm{~kg} / \mathrm{ha}$ de $\mathrm{P}_{2} \mathrm{O}_{5}$, sendo que a densidade foi de 10 plantas por metro linear. Segundo os autores obteve-se em Campinas e Monte Alegre do Sul, no ciclo das "se cas" efeitos significativos para níveis de adubação e cultiva res. Carioca, Rico 23 e Bico-de-Ouro mostraram respostas lineares significativas até o nível mais elevado de adubação sendo que a cultivar Carioca, foi a de maior produção em todos os níveis pesquisados. Já no ciclo das "águas", em Campinas , não se observou qualquer efeito significativo da adubação mineral, mas da mesma forma a cultivar Carioca suplantou as de- 
mais em todos os níveis pesquisados. Porém, em Monte Alegre do Sul, as cultivares foram semelhantes nos níveis mais baixos de adubação, porém, comportaram-se diferentemente em níveis mais altos de fertilização. Os autores observaram ainda, que apesar do pequeno número de cultivares de feijoeiro em estudo, ficou evidenciado que há variabilidade dentro desta espēcie, em relação à sua resposta à aplicação de fertilizantes. As cultivares Carioca e Rico 23 foram, com maior freqüência, as que mostraram acrēscimo de produção conforme eram aumentadas as quantidades de fertilizantes aplicados.

FRIZZONE et alii (1982) verificando o efeito da irrigação e da adubação fosfatada em feijão cultivar cario ca, em Ilha Solteira - SP, verificaramque a aplicação de āgua aumentou linearmente a produção de grãos nos níveis de 50 a $100 \mathrm{~kg}$ de $\mathrm{P}_{2} \mathrm{O}_{5} / \mathrm{ha}$. Constataram ainda, que a maior eficiência de uso de água em $\mathrm{kg}$ de grãos produzidos por $\mathrm{m}^{3}$ de água aplicada foi verificada no tratamento $350 \mathrm{~mm}$ de ăgua e $100 \mathrm{~kg} / \mathrm{ha}$ de $\mathrm{P}_{2} \mathrm{O}_{5}$

Objetivando verificar a resposta das cultiva res de feijão Rico Baio 1014 e Carioca, a diferentes fontes e formas de adubação fosfatada, JUNQUEIRA NETO et alii (1982) realizaram um ensaio de campo em Três Pontas - MG, no período das "águas". Os autores utilizaram quatro níveis de fósforo: 60, 120,240 e $480 \mathrm{~kg} / \mathrm{ha}$ de $\mathrm{P}_{2} \mathrm{O}_{5}$ nas formas de fosfato de Patos de Minas e superfosfato triplo. Conforme observação dos autores, as plantas de feijão não responderam convenientemente à aduba 
ção de fósforo na forma de fosfato natural aplicada a lanço e no sulco, comparativamente à aplicação de superfosfato triplo no sulco. As aplicações de fósforo, nas diversas formas, níveis e fontes, tiveram efeitos lineares proporcionando aumentos na produção de grãos, em relação à testemunha, de 51,03\% para Rico Baio 1014 e 60,65\% para a Carioca 1030.

Resultados obtidos por OLIVEIRA et alii (1982a), em experimento visando detectar os efeitos de macro e micronu trientes na cultura do feijão, em solos sob vegetação de cerrado em Goiānia-Go, mostraram que o fósforo foi o elemento que mais influenciou a produção da cultura, vindo a seguir o zinco. Em outro experimento, visando verificar efeitos de níveis de fósforo, população de plantas e hábito de crescimento na cultura do feijoeiro OLIVEIRA et alii (1982b), observaram que no primeiro ano em período de chuva escassa houve efeito linear da adubação na produção, não havendo influência dos outros pa râmetros. No segundo ano, verificou-se efeito significativo do hábito de crescimento, cultivar, adubação e população de plan tas sobre a produção de grãos. As cultivares Pintado (hábito I), Rico 23 (hábito II) e IPA 7419 (hábito III), produziram em mẹ dia $421,1.130$ e $1.025 \mathrm{~kg} / \mathrm{ha}$ respectivamente.

Em experimento visando verificar os efeitos de densidades de plantas e adubação fosfatada, em feijão culti var Carioca, SĀ et alii (1982), verificaram que os tratamentos $\mathrm{P}_{3} \mathrm{D}_{2}\left(100 \mathrm{~kg} / \mathrm{ha}\right.$ de $\mathrm{P}_{2} \mathrm{O}_{5}$ e $18 \mathrm{plantas} / \mathrm{metro}$ linear $)$ e $\mathrm{P}_{2} \mathrm{D}_{3}(100$ $\mathrm{kg} / \mathrm{ha}$ de $\mathrm{P}_{2} \mathrm{O}_{5}$ e 23 plantas/metro linear) foram os que apresen 
taram melhores resultados com relação à produção de grãos. Os autores observaram ainda que nas condições do experimento hou ve influência da adubação fosfatada e da densidade de plantas na produção e número de vagens por planta. Também, VIDAL e JUN QUEIRA NETO (1982) estudando os efeitos da densidade de plan tas e de doses de fósforo sobre a produção de duas cultivares de feijão (Carioca 1030 e Jalo), em Caldas-MG, verificaramque a aplicação de fósforo provocou aumentos em todas as características, ocorrendo diferenças varietais de resposta para pro dução de sementes, número de vagens por parcela e peso médio de 100 sementes.

THUNG et alii (1982), na Colômbia, realizaram um experimento para verificar os efeitos de formas de aplicação (5 e $25 \mathrm{~cm}$ de profundidade) e níveis de fósforo (0-150 e $300 \mathrm{~kg} / \mathrm{ha}$ de $\mathrm{P}_{2} \mathrm{O}_{5}$ ) em quatro cultivares de feijão: Carioca, G 4000, ICA-Pijao e Puebla 152. Segundo os autores, os resultados indicaram que a dose de $150 \mathrm{~kg} / \mathrm{ha}$ de $\mathrm{P}_{2} \mathrm{O}_{5}$ foi a que apresentou maior rendimento, com aumentos do número de vagens por planta e número de sementes por planta.

\subsection{Densidade de plantas}

Diversas densidades de plantas têm sido testạ das na cultura do feijoeiro, com as mais diversas variações, desde 100.000 até 1.000 .000 de plantas por hectare, dependendo do espaçamento entre linhas. Tradicionalmente, o uso de 
200.000 plantas por hectare tem sido o comumente usado, mas em termos experimentais há uma certa controvérsia.

VIEIRA e ALMEIDA (1965) realizaram cinco experimentos sobre espaçamento e quantidade de sementes nos sulcos, nos períodos das "águas" e das "secas" entre os anos de 1960 a 1964, com a cultivar Rico 23. Os resultados obtidos mostraram que quanto à distribuição das sementes a maior produção foi conseguida com o emprego de uma semente de $10 \mathrm{em} 10 \mathrm{~cm}$ e a pior com três sementes de 30 em $30 \mathrm{~cm}$.

Utilizando os espaçamentos de 40 e $50 \mathrm{~cm}$ entre linhas e as distâncias de $2,5 \mathrm{~cm}, 5 \mathrm{~cm}, 7,5 \mathrm{~cm}$ e $10 \mathrm{~cm}$ entre sementes dentro dos sulcos de semeadura, VIEIRA (1968) insta lou cinco experimentos no período das "águas" e das "secas"de 1965 a 1968. Essas densidades produzem populações de1.000.000, $500.000,333.333$ e 250.000 plantas por hectare, supondo um "stand" de 100\% no espaçamento de 40cm; e 800.000, 400.000, 266.666 e 200.000 plantas por hectare, no espaçamento de $50 \mathrm{~cm}$, respectivamente. A análise estatística conjunta dos dados dos cinco ensaios acusou diferenças significativas entre as densi dades e, pelo teste de Duncan a $5 \%$; o intervalo de $5 \mathrm{~cm}$ foi su perior aos demais com exceção do de $7,5 \mathrm{~cm}$.

AGUDELO et alii (1972) na Colômbia, realizaram estudos para determinar a ótima densidade de plantas, os componentes do rendimento e outras características agronômicas e fisiológicas (acumulação de matéria seca em cinco estádios de crescimento) das cultivares de feijão Diacol Calima tipo ar- 
bustivo e Ica Huasano tipo prostado, usando populações de $333.333 ; 250.000 ; 200.000$ e 166.666 plantas/ha em ensaio de parcela subdividida com quatro repetições. Concluíram que uma população de 250.000 plantas/ha parece ser a mais indicada pa ra obter altos rendimentos em ambas variedades. Dos componentes do rendimento, o número de vagens por planta foi o mais a fetado pelas variações de população, sendo mais baixo quando ela é mais alta. O indice de colheita permaneceu constante den tro de uma mesma cultivar.

Experimentos realizados por SANTA CECILIA et alii (1974) em Lavras e Campo-Belo-MG, visaram verificar os e feitos de espaçamentos entre linhas e densidades sobre a produtividade do feijoeiro cultivar Rico 23. Em Lavras não se ob servou diferença significativa entre os tratamentos, porém, em Campo Belo, ocorreu. Nos intervalos de 2,5 e 5,0 cm dentro das linhas, os rendimentos foram significativamente superiores aos de $10 \mathrm{~cm}$, mas não diferiram entre si.

Em estudos realizados por BATISTA et alii (1975) visando verificar os efeitos de diversos fatores sobre o comportamento do feijoeiro cultivar Rico 23 foi observado que as densidades de semeadura não influenciaram a absorção de micro nutrientes pelas plantas. Conforme CROTHERS e WESTERMANN (1976) as produções de sementes de feijão não têm sido aumentadas sob os sistemas de produções correntes e que um dos motivos seria o número inadequado de plantas por área. Estes autores mostra ram que a ótima população de plantas foi de 400.000 plantas/ha . 
Em estudos realizados por BENNETT et alii (1977) foi observado em feijão das secas que o número de vagens por planta é o mais sensível componente da produção sob alta densidade de plantio. Os autores utilizaram-se de sete cultivares de feijão sob às densidades de 17, 21, 34 e 63 plan tas $/ \mathrm{m}^{2}$ e analisaram a maturação por ramos, nümero de rācemos, vagens e nōs. Verificaram que somente rácemos por nōs e ramificações por planta foram significativamente reduzidos pela alta densidade de plantas.

De acordo com PONS et alii (1980) os rendimentos mais altos na cultura do feijoeiro são obtidos com densidades em torno de 200.000 plantas/ha, podendo oscilar entre 120.000 e 240.000 plantas. Quando as condições são favoráveis ao desenvolvimento, os rendimentos na amplitude das densidades mencionadas tendem a se aproximar. Em caso contrário, geral mente há vantagens no uso das densidades mais altas de plantas, para compensar, em parte, o menor rendimento das plantas individualmente.

Recomendações do CIAT (1981) são que quando se usa cultivar suscetíveis a doenças deve-se usar densidades menores, uma vez que a elevada densidade de plantas favorece o desenvolvimento de enfermidades nestes materiais.

FARIA e KRANZ (1982) estudando os efeitos de e $\underline{s}$ paçamento e densidades em feijoeiro de porte I, II e III, no norte e centro do Paraná, concluíram através dos resultados obtidos que a melhor densidade foi de 10 a 15 plantas por metro 
linear num espaçamento de $50 \mathrm{~cm}$ para cultivares de qualquer dos portes testados.

Em experimento visando verificar os efeitos de densidade de plantas e da adubação fosfatada sobre a produção e alguns fatores de produção do feijoeiro cultivar Carioca, SA et alii (1982) observaram que tanto densidades como adubação influíram na produção e número de vagens por planta. Constataram ainda que houve uma certa tendência de se obter maior nú mero de vagens por planta quando se utilizou menores densida des. Este fato foi também ratificado por SANTANA e SIIVA (1982) na Bahia, que realizou diversos experimentos para verificar os efeitos de espaçamentos, densidades e sistemas de semeadura na produção do feijoeiro cultivar IPA-7419.

Como se observa, nem sempre a literatura é con cordante no que se diz respeito aos efeitos da densidade de plantas sobre a produção e outras características do feijoei ro. No entanto, dependendo das condições locais, da cultivar, de condições climáticas, este parâmetro pode ter grande in fluência no rendimento final da cultura.

\subsection{Metedodos de análise e qualidade das sementes}

O objetivo fundamental da anālise de sementes

é determinar a qualidade das mesmas a fim de que os agriculto res possam ter uma informação segura para adquiri-las e semeá-las, TOLEDO e MARCOS FILHO (1977). 
Dentre os testes utilizados para avaliar as con dições das sementes e portanto suas qualidades, estão o teste padrão de Germinação e os testes de vigor. No entanto, ainda não existe uma padronização de modo que se possa indicar um determinado teste de vigor para as diferentes espëcies, havendo una bus ca constante dos pesquisadores em obter resultados que possam permitir a melhor utilização de um teste, ou conjunto deles, mais adequados a uma determinada espécie.

O teste mais usado para verificar a qualidade das sementes è o teste padrão de germinação. No entanto, exí tem críticas quanto somente à sua utilização, uma vez que os testes de germinação acusam a condição fisiológica atual do lote, não fornecendo informações sobre o seu potencial de con servação e possível desempenho no campo. Outro fato é que o teste de germinação é realizado com o objetivo de se conhecer a germinação das sementes sob condições artificiais altamente favoráveis. Já o teste de vigor visa submeter as sementes a condições adversas, simulando, desta maneira, o comportamento das sementes em condições de campo.

Por outro lado, desde que se reconheça suas li mitações, o teste de germinação tem grande utilidade, principalmente por envolver procedimentos padrões e originar resultados relativamente uniformes entre os diferentes laboratórios, TOLEDO e MARCOS FILHO (1977), CARVALHO e NAKAGAWA (1980). Diversos são os métodos utilizados para se tes tar o vigor das sementes, tais como: teste de frio, envelheci 
mento rápido, velocidade de germinação, primeira contagem de germinação, teste de tetrazólio, velocidade e porcen tagem de emergência das plântulas no campo.

Diversos trabalhos têm sido efetuados com fins de se adequar testes que avaliem melhor a qualidade de sementes.

WEBSTER e DEXTER (1961) ao estudarem as possibilidades de avaliação da qualidade de sementes de algumas es pécies através de dados da germinação, velocidade de germinação e vigor das plântulas, após serem submetidas a diversas in júrias, entre elas choques mecânicos e armazenamento sob alta umidade relativa, observaram que sementes de feijão com 9: e 13\% de umidade submetidas a choques provocados por um cilin dro girando a $1.000 \mathrm{rpm}$, demonstravam maior sensibilidade aos danos quanto mais secas estivessem, refletida mais seguramente pela porcentagem e velocidade de germinação.

Utilizando o método do envelhecimento rápido para avaliar o vigor de sementes de feijão, ABRAHÃO e TOLEDO (1969) observaram que a permanência de 48 horas na câmara de envelhecimento foi melhor que 24 horas para se avaliar o vigor das sementes das diversas cultivares.

Ao utilizar vários testes de vigor em sementes de feijoeiro a fim de avaliar-lhes o vigor, SARTORI (1971) concluiu que o teste do envelhecimento rápido tinha sido o mais eficiente, verificando ainda que dentre os testes, o de germinação revelou-se como o menos indicado. 
MARCOS FILHO e GODOY (1974) utilizaram os testes de germinação, velocidade e porcentagem de emergência no campo para avaliar a qualidade de sementes de feijão Goiano Pre coce irradiadas e conservadas em câmara seca. Os autores observaram que os testes de vigor são mais indicados para este tipo de estudo por serem mais rigorosos que os de germinação. Experimento realizado em Campinas-SP, no Insti tuto Agronômico por MAEDA et alii (1982), visou comparar os testes de germinação e envelhecimento rāpido na avaliação da qualidade de lotes de sementes de feijão. As sementes foram colocadas em câmara de en velhecimento (420 C e 100\% de UR) por 1, 2, 3 e 4 dias com fins de se definir o número de dias ideal para execução do teste em sementes de feijão, procurando classificar os lotes em diferentes níveis de vigor. Através dos resultados obtidos os autores concluíram que o tempo de 3 dias foi o que melhor discriminou os lotes e que o teste de germinação não permitiu uma boa discriminação dos mesmos.

A planta bem nutrida está em condições de produzir sementes bem formadas e de suportar melhor as condições adversas. A exigência nutricional para a maioria das espécies torna-se mais intensa com o início da fase reprodutiva, sendo mais crítica por ocasião da formação das sementes, quando con siderável quantidade de nutrientes, geralmente fósforo e nitrogênio são para elas translocadas. A disponibilidade de nutrientes influi na boa formação do embrião e do órgão de reserva, assim como na sua composição química e, conseqüentemen 
te, no metabolismo e no vigor da semente.

BASTOS et alii (1982), em Lavras-MG, verifican do os efeitos de fósforo, molibdênio e cobalto sobre a germinação e vigor (envelhecimento precoce) de sementes de feijão, verificaram que o fósforo, de modo geral, proporcionou aumento na germinação; já no vigor, foi benéfico em todas as épocas ; o cobalto, na presença de molibdênio, contribuiu com um aumen to no vigor e na germinação das sementes; o cobalto, na presença do fósforo, foi prejudicial à germinação; o molibdênio, na presença do fósforo, favoreceu o vigor das sementes.

Determinando a composição química de sementes de algumas espécies, WATT e MERRIL (1963) determinaram o teor de proteĩna em feijão branco, feijão vermelho e feijão preto obtendo os valores de $22,3 \%, 22,5 \%$ e $22,3 \%$, respectivamente.

FONSECA et alii (1974), em Piracicaba, determi nando os componentes minerais e orgânicos de algumas variedades de feijão, obtiveram valores médios de $21,5 \%$ de proteína e $0,17 \%$ de fósforo.

Conforme VIEIRA (1978) é elevado o teor de prọ teína no feijão, o qual varia de 15 a 33\%, sendo que a maioria das variedades plantadas no Brasil, entretanto, apresentam de 20 a 25\% de proteína. 


\section{MATERIAIS E MÉTODOS}

\subsection{Local do ensaio}

o ensaio foi instalado em solo sob vegetação de cerrado, latossolo vermelho escuro, textura argilosa conforme DEMATTE (1980), na Fazenda Experimental da UNESP, "Campus" de Ilha Solteira, localizada no Município de Selvíria, MS.

\subsubsection{CARACTERÍSTICAS DO LOCAL}

o solo onde se instalou o ensaio estava no ter ceiro ano de cultivo sendo que foram realizadas as seguintes operaçôes no mesmo, a partir de 1978 até a época da semeadura do feijão: desmatamento, enleiramento e queima, destoca e desenraizamento, aração e gradagem nos meses de julho e calagem na quantidade de 4 t/ha em agosto de 1978. Em setembro de 1978 
foi realizada uma fosfatagem aplicando-se $240 \mathrm{~kg} / \mathrm{ha}$ de fosfato natural e na segunda quinzena de novembro foi feito na ārea a sëmeadura de soja cv. IAC-2.

Em 1979, novamente a área foi cultivada com soja, sendo que devido a problemas de seca a produção foi bai xa e não foi realizada a colheita, sendo que o material foi incorporado ao solo, e que nos dois cultivos a cultura recebeu a seguinte adubação: $100 \mathrm{~kg}$ de sulfato de amônio, $400 \mathrm{~kg}$ de superfosfato simples, $60 \mathrm{~kg}$ de cloreto de potássio e $50 \mathrm{~kg}$ de FTE-BR-9.

Em setembro de 1980, foram realizadas aração e gradagem na área, sendo que neste ano a área não foi cultivada. Em fevereiro de 1981 foi feita uma anälise de solo no local, sendo que os resultados da análise estão expres sos a seguir:

\begin{tabular}{cccccc}
\hline & & & $\mathrm{m} \mu / \mathrm{ml}$ & de TFSA & e. mg/100 g TFSA \\
\cline { 3 - 6 } & $\begin{array}{c}\mathrm{pH} \\
\left(\mathrm{H}_{2} \mathrm{O}\right)\end{array}$ & $\mathrm{P}$ & $\mathrm{K}$ & $\mathrm{Ca}^{++}+\mathrm{Mg}^{++}$ & $\mathrm{Al}^{+1}$ \\
\hline 1,2 & 5,4 & 12 & 186 & 2,8 & 0,4 \\
\hline
\end{tabular}

Foi feita então uma calagem no solo aplicando- se 2 toneladas por hectare de calcário dolomítico com 60\% de PRNT, sendo que o calcário foi incorporado ao solo com uma gra dagem pesada. 
Em junho a área sofreu aração, gradagem e então procedeu-se à semeadura do experimento.

\subsection{AdubaçÃ̃o}

A adubação foi feita manualmente colocando - se no sulco $1 / 3$ do nitrogênio, todo o fósforo que constituiu par te dos tratamentos e o potássio. Junto a estes macronutrientes foram adicionados $50 \mathrm{~kg} / \mathrm{ha}$ de FTE-BR-9 para o fornecimento de micronutrientes. Os adubos utilizados para fonte de $\mathrm{N}$,

$\mathrm{P}_{2} \mathrm{O}_{5}$ e $\mathrm{K}_{2} \mathrm{O}$ foram sulfato de amônio, superfosfato simplese clo reto de potássio, respectivamente.

As doses utilizadas foram:

- N $\quad-50 \mathrm{~kg} / \mathrm{ha}$

- $\mathrm{P}_{2} \mathrm{O}_{5}-0 \mathrm{~kg}, 75 \mathrm{~kg}$ e $150 \mathrm{~kg} / \mathrm{ha}$

- $\mathrm{K}_{2} \mathrm{O}-60 \mathrm{~kg} / \mathrm{ha}$

O restante do $\mathrm{N}$ foi colocado em cobertura 15 dias após a emergência das plântulas.

\subsection{SemENTES}

As sementes utilizadas para o ensaio foram obtidas da seguinte maneira:

- Semente da cultivar Goiano Precoce, cedida pelo Prof. Dr. Oswaldo Pereira Godoy da ESALQ - Piracicaba. 
- Semente da cultivar Bolinha, cedida por um agricultor da região.

- Semente da cultivar Carioca, obtida de um lote de sementes básicas que foi cedido pelo CATI a este "Campus", para multiplicação.

- Semente da cultivar Rico 23, obtida da multiplicação de um material que nos foi cedido pelo Instituto Agronômico de Campinas em 1978 .

\title{
3.4. Delineamento experimental
}

\begin{abstract}
Utilizou-se o esquema fatorial $4 \times 3 \times 2$, cujos tra tamentos foram distribuídos em blocos casualizados com 4 repe tições.
\end{abstract}

Das combinações de quatro cultivares (Carioca, Goiano Precoce, Bolinha e Rico 23), três doses de fósforo (0 kg, $75 \mathrm{~kg}$ e $150 \mathrm{~kg}$ de $\mathrm{P}_{2} \mathrm{O}_{5} / \mathrm{ha}$ ) e duas densidades (10 e 15 plantas por metro linear) resultaram os seguintes tratamentos:
1. GP Dl PO
2. GP D2 P0
3. GP DI Pl
4. GP D2 P1
5. GP DI P2
6. GP D2 P2
7. B Dl PO 


$$
\begin{aligned}
& \text { 8. B D2 P0 } \\
& \text { 9. } \mathrm{B} \text { DI Pl } \\
& \text { 10. B D2 Pl } \\
& \text { 11. B Dl P2 } \\
& \text { 12. B D2 P2 } \\
& \text { 13. C Dl PO } \\
& \text { 14. C D2 P0 } \\
& \text { 15. C Dl Pl } \\
& \text { 16. C D2 P1 } \\
& \text { 17. C D1 P2 } \\
& \text { 18. C D2 P2 } \\
& \text { 19. } \mathrm{R} \text { DI PO } \\
& \text { 20. R D2 P0 } \\
& \text { 21. R Dl Pl } \\
& \text { 22. } \mathrm{R} \text { D2 } \mathrm{Pl} \\
& \text { 23. R DI P2 } \\
& \text { 24. } \mathrm{R} \text { D2 } \mathrm{P} 2
\end{aligned}
$$

sendo: GP (Goiano Precoce), B (Bolinha), C (Carioca), R (Rico 23), D1 (10 plantas/m linear), D2 (15 plantas $/ \mathrm{m}$ linear), P0 (0 $\left.\mathrm{kg} \mathrm{P} 2_{2} \mathrm{O}_{5} / \mathrm{ha}\right), \mathrm{Pl}\left(75 \mathrm{~kg} \mathrm{P} \mathrm{O}_{5} / \mathrm{ha}\right)$ e $\mathrm{P} 2$ (150 kg $\left.\mathrm{P}_{2} \mathrm{O}_{5} / \mathrm{ha}\right)$.

\section{4 .1 . TAMANHO DAS PARCELAS}

Cada parcela foi formada por 8 linhas de $5 \mathrm{~m}$ de comprimento espaçadas de $0,50 \mathrm{~m}$, ou seja $20 \mathrm{~m}^{2}$.

Foram consideradas como bordaduras as duas linhas laterais e $0,5 \mathrm{~m}$ nas extremidades de cada parcela resultando a área ütil de $12 \mathrm{~m}^{2}$ por parcela. 


\subsection{2, ÁREA DO EXPERIMENTO}

A área total do experimento foi de $1.920 \mathrm{~m}^{2}$, com ārea útil de $1.152 \mathrm{~m}^{2}$.

\subsection{Semeadura}

Foi realizada em 12 de junho de 1981, no espaçamento de $50 \mathrm{~cm}$ entre fileiras. Foram semeadas 15 e 20 semen tes por metro linear para se obter as densidades de 10 e 15 plantas por metro após o desbaste com as sementes apresentando $90 \%$ de germinação.

A germinação das sementes ocorreu entre os dias 18 e 20.06.81, obtendo-se um ótimo stand, não havendo necessí dade de se fazer uma re-semeadura.

\subsection{Tratos culturais}

\section{$3,6,1$, DESBASTE}

A retirada do excesso de plantas, para que 0 experimento fosse conduzido nas densidades desejadas, foi fe ta 12 dias após a emergência das plântulas, ou seja em 30.06.81. 


\section{$3,6,2$, CAPINAS}

Durante o ciclo da cultura foram feitas duas capinas manuais, a primeira aos 15 dias após a emergência da cultura e a segunda aos 40 dias após a emergência, sendo que depois não houve necessidade de novas capinas.

\section{3,6.3. CONTROLE DE PRAGAS E MOLÉSTIAS}

Os tratos fitossanitários iniciaram-se logo na instalação da cultura de forma que antes da semeadura foi aplicado no sulco TEMIG $10 \mathrm{G}$ (aldicarb) na dose de $2 \mathrm{~kg} / \mathrm{ha}$ de p.a.

Foram realizadas 5 pulverizações durante o ciclo da cultura para se prevenir contra as pragas e moléstias. Em todas as pulverizações foi utilizado um espalhante adesi vo, na dose de $100 \mathrm{ml} / 400$ litros de calda.

- 1ạ - 10 dias após a emergência:

AZODRIN $60 \mathrm{E}$ (monocrotofós) + DITHANE M-45 (maneb) : $500 \mathrm{~g}+500 \mathrm{~g} / \mathrm{ha} \mathrm{p.c.}$

- $2^{a}$ - 25 dias após emergência:

LANNATE 90 PS (metomil) + BENLATE (benomyl): $400 \mathrm{~g}+$ $500 \mathrm{~g} / \mathrm{ha}$ p.c.

- 3ạ - 32 dias após emergência - para controle de oídio: PLANTVAX $200 \mathrm{~g} / \mathrm{ha}$ p.c. 
- 4ạ - 40 dias apôs emergência:

AZODRIN 60 E (monocrotofós) + DITHANE M-45 (maneb) : $500 \mathrm{~g} / \mathrm{ha} \mathrm{p.c.}$

- 5ạ - 65 dias após emergência (somente para Carioca e Rico 23) LANNATE 90 PS (metomil) + BENLATE (benomyl): $400 \mathrm{~g}+$ $500 \mathrm{~g} / \mathrm{ha} \mathrm{p.c.}$

\section{6 .4 . IRRIGAÇÃO}

Como o período em que foi instalada a cultura no campo apresenta muito baixa pluviosidade, a cultura foi conduzida mediante o uso de irrigação. No entanto, esta prátí ca já está se tornando rotineira em alguns estados brasileiros, uma vez que a irrigação conforme CAIXETA (1978) tem sido um fator capaz de aumentar a produção do feijoeiro represen tando um incremento substancial.

Durante o experimento foram feitas irrigações de $50 \mathrm{~mm}$ a cada 10 dias, sendo que a partir do florescimento o turno passou para sete dias, até a maturação das vagens, quando então não mais se irrigou o experimento. Esta quantida de de água aplicada baseou-se em trabalhos de FRIZZONE* et alii (1982) em Ilha Solteira, que encontraram uma evapotranspira ção média diária para a cultura de 5,2 mm e uma evaporação média diāria no tanque Classe $A$, de $7,5 \mathrm{~mm}$. Sabe-se no entanto que a quantidade de água a se aplicar, o número de irrigações e o intervalo entre elas, dependem principalmente das condi * Comunicado particular. Trabalho publicado em 1982. 
ções climáticas locais, das características físico - hídricas dos solos, do sistema de irrigação e da cultivar usada. CAIXE TA et alii (1978) e GARRIDO et alii (1979) obtiveram ótimas produções em cultura no Norte de Minas Gerais quando aplica ram o equivalente a $5 \mathrm{~mm} /$ dia. Já PURCINO et alì (1978) no sul daquele estado obtiveram ótimas produções quando aplicaram em média 3,2 mm/dia.

Devido as diferenças nos ciclos das cultivares,

o nümero de irrigações foi de sete para Goiano Precoce e Boli nha e nove para Carioca e Rico 23.

\section{T. FLORESCIMENTO}

O florescimento das parcelas de cada variedade se deu nas seguintes épocas:

- Goiano Precoce: 16.07.81

- Bolinha : 16.07.81

- Carioca : 03.08 .81

- Rico $23 \quad: 07.08 .81$

\subsection{Determinação da altura de plantas}

No início da maturação foi determinada a altura de plantas (média em $\mathrm{cm}$ ) medindo-se 10 plantas ao acaso por parcela. 
Utilizou-se do método descrito por SIIVA (1981) medindo-se a distância entre o colo da planta e o āpice da haste principal.

\subsection{Colmeita}

A colheita foi efetuada manualmente, sendo que as cultivares Goiano Precoce e Bolinha foram colhidas em 01.09.81 e as cultivares Carioca e Rico 23 em 20.09.81. Colheu-se sepa radamente 10 plantas por parcela para se determinar o nümero de vagens por planta e nümero de sementes por vagem.

Após a colheita, as sementes foram secadas ao ar livre e armazenadas em sacos de papel em condições de labo ratório. Três meses depois foram feitas as determinações de laboratório.

\subsection{Determinações de Laboratório}

As determinações de laboratório foram iniciadas em 12.11.81 até 15.01.82 com fins de avaliar a qualidade das sementes.

Nas amostras retiradas dos materiais armazenados foram efetuadas as determinações de germinação, vigor, teor de umidade, peso de mil sementes, teor de proteína e de fósforo nas sementes.

As determinações de germinação, 'vigor, teor de 
umidade e peso de mil sementes foram realizadas no Laboratório de Análise de Sementes do Departamento de Agricultura e Horticultura da Escola Superior de Agricultura "Luiz de Queiroz" - USP. As determinações do teor de proteína e teor de fós foro nas sementes foram realizadas no Laboratório de Solos e Nutrição de Plantas do Departamento de Solos e Adubos da UNESP, "Campus" de Ilha Solteira. Os dados obtidos em porcentagem fo ram transformados em arc sen $\sqrt{\frac{0}{\circ} / 100}$.

\subsubsection{TESTE DE GERMINAÇÃO}

O teste foi instalado em germinador de marca BURROWS, regulado para manter a temperatura alternada de 20-30 ${ }^{\circ} \mathrm{C}$, utillizando-se papel toalha (xuga) como substrato, na forma de rolo de papel. Para realização do teste de germina ção foram tomadas quatro subamostras de 50 sementes para cada um dos diferentes tratamentos.

As contagens foram efetuadas aos 5 e 7 dias apôs a instalação do teste (não houve necessidade de se contar aos 9 dias) e a interpretação dos resultados foi realizada con forme critérios estabelecidos pelas Regras para Análise de Sementes (BRASIL, 1976). 


\subsubsection{TESTES DE VIGOR}

Para avaliação do vigor das sementes foram uti lizados os seguintes testes: primeira contagem do teste de ger minação, velocidade de germinação e envelhecimento rápido.

\subsubsection{Primeira contagem de germinação}

Foi realizado em conjunto com o teste de germi nação, computando-se as plântulas normais verificadas no quin to dia após a semeadura ou seja, o nümero de plântulas normais removidas na primeira contagem do teste de germinação.

\subsubsection{Velocidade de germinação}

Tambēm este teste foi conduzido em conjunto com o teste padrão de germinação, com contagens diārias do número de plântulas normais, sendo que para uma boa precisão do teste, as contagens foram realizadas sempre a mesma hora.

o cálculo da velocidade de germinação foi feito empregando-se a fórmula apresentada por MAGUIRRE (1962):

$$
\mathrm{V} \cdot \mathrm{G} \cdot=\frac{\mathrm{N}_{1}}{\mathrm{D}_{1}}+\frac{\mathrm{N}_{2}}{\mathrm{D}_{2}}+\ldots+\frac{\mathrm{N}_{\mathrm{n}}}{\mathrm{D}_{\mathrm{n}}}
$$

onde: $\quad \mathrm{N}=$ nümero de plântulas normais germinadas; $\mathrm{D}=$ nümero de dias após a instalação do teste. 


\subsubsection{Envelhecimento precoce}

Foi realizado tomando-se 4 subamostras de 50 sementes de cada um dos tratamentos, que foram colocadas em recipientes plásticos de fundo perfurado e levadas para a câmara de envelhecimento, onde foram mantidas à $420 \mathrm{C}$ de tempera tura e aproximadamente 100\% de umidade relativa do ar durante 72 horas conforme MAEDA et alii (1982). Após este período, as sementes foram colocadas para germinar conforme prescrições das Regras para Análise de Sementes (BRASIL, 1976), durante 5 dias.

Para interpretação deste teste foi adotado o critério descrito por DELOUCHE e BASKIN (1973), determinando- se as porcentagens de plântulas com radícula e parte aérea i dentificāveis, independente de seu tamanho, aparência e sanidade.

\subsubsection{DETERMINAÇÃO DO TEOR DE UMIDADE}

Para determinação do teor de umidade das semen tes tomou-se duas amostras de aproximadamente 25 gramas de ca da um dos materiais, as quais foram pesadas em balança de pre

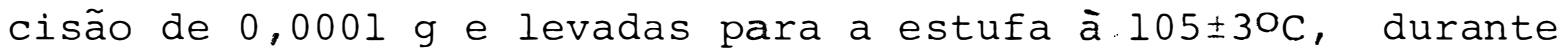
24 horas conforme prescrições das Regras para Análise de Sementes (BRASIL, 1976). 


\subsection{0 .4 , PESO DE MIL SEMENTES}

Foi avaliado conforme prescrições das Regras para Análise de Sementes (BRASIL, 1976), com 8 subamostras de 100 sementes para cada um dos materiais, utilizando-se balança de precisão de $0,1 \mathrm{~g}$.

\subsection{0,5. DETERMINAÇÃO DO TEOR DE PROTEİNA E FÓSFORO NAS SEMENTES}

Foram retiradas 4 subamostras de aproximadamen te $25 \mathrm{~g}$ de sementes de cada um dos materiais, para determinar o teor de proteina e de fósforo nas sementes, sendo que o teor de proteína foi obtido a partir do teor de nitrogênio.

A determinação do fósforo foi realizada em material seco em estufa de circulação forçada de ar à temperatu彑 ra de $70^{\circ} \mathrm{C}$ e moído em moinho Wiley peneira no 20. Deste mate rial foi feito um extrato nitrico-perclórico e as análises fo ram efetuadas em alíquotas dos mesmos, sendo que se utilizou do método colorimétrico para determinar o teor de $\mathrm{P}$ nas alí quotas.

Foram feitas duas determinações por amostra, to talizando 192 análises, sendo que as análises estatisticas fo ram feitas com os dados médios das duas repetições.

A determinação do nitrogênio total foi feita a través do método de microkjeldhal, descrita em MALAVOLTA (1957). 
A partir dai, calculou-se o teor de proteina, multiplicando-se o valor do nitrogênio por 6,5 .

\subsection{ANÁLISE ESTATİSTICA}

Foram realizadas as análises de variância usuais, com desdobramento dos graus de liberdade onde se fez ne cessário para sua boa interpretação.

Como parte complementar onde se fez necessário, foi aplicado o método de Tukey para o confronto entre as mé dias, ao nível de 5\% de probabilidade, obtendo-se a diferença minima significativa (D.M.S.). O esquema das análises realizą das está contido na Tabela 1 .

TABETA 1 - Esquema da análise de variância utilizada na avaliação dos dados coletados.

\begin{tabular}{lc} 
Causas de variação & G.L. \\
\hline Blocos & 3 \\
Cultivares & 3 \\
Fósforo & 2 \\
Densidade & 1 \\
Interação Cultivares x Fösforo & 6 \\
Interação Cultivares x Densidade & 3 \\
Interação Fösforo x Densidade & 2 \\
Interação Cultivares x Fósforo x Densidade & 6 \\
(Tratarnentos) & $(23)$ \\
Resíduo & 69 \\
\hline TOTAL & 95 \\
\hline
\end{tabular}




\subsection{RESULTADOS E DISCUSSÃO}

\subsection{Altura de plantas}

A análise da variância dos dados obtidos para altura de plantas acha-se contida na Tabela 2. O valor de $F$ obtido para cultivares, altamente significativo, indica um comportamento diferente das cultivares em relação a este parâa metro. Porém, este fato já era esperado, uma vez que, as cultivares Goiano Precoce e Bolinha são de hábito de crescimento determinado tipo 1, a cultivar Rico 23 é de hábito de crescimento indeterminado tipo 2 e a cultivar Carioca de hábito de crescimento indeterminado tipo 3 (porēm pode se comportar com hábito "intermediārio" entre 2 e 3, conforme SILVA, 1981), e portanto devendo apresentarem diferentes portes. 
Tabela 2 - Altura de plantas (an). Análise da variância do dados obtidos.

\begin{tabular}{|c|c|c|c|c|}
\hline Causas de variação & G.L. & $S 2$ & $Q M$ & F \\
\hline Blocos & 3 & 0,17559 & 0,05853 & $0,09 \mathrm{~ns}$ \\
\hline Cultivares (Cv.) & 3 & 4934,48972 & 1644,82990 & $2797,33 * \star$ \\
\hline Doses de Fósforo (P) & 2 & 782,23925 & 391,11962 & $665,17 * \star$ \\
\hline Densidades (D) & 1 & 2,13031 & 2,13031 & $3,62 \mathrm{~ns}$ \\
\hline Interação $\mathrm{CV} \cdot \mathrm{xP}$ & 6 & 308,35742 & 51,39290 & $87,40 \star \star$ \\
\hline Interação $\mathrm{Cv} \cdot \mathrm{xD}$ & 3 & 7,05767 & 2,35255 & $4,00 \star$ \\
\hline Interação PxD & 2 & 7,31500 & 3,65750 & $6,22 * \star$ \\
\hline Interação Cv.xPxD & 6 & 31,09323 & 5,18220 & $8,81 * \star$ \\
\hline Resĩduo & 69 & 40,57189 & 0.58799 & \\
\hline TOTAL & 95 & 6113,43012 & & \\
\hline Doses de Fōsforo' & 1 & 765,90562 & 765,90562 & $1320,56 * \star$ \\
\hline Doses de Fösforo" & 1 & 16,33333 & 16.33333 & $27,77 \star \star$ \\
\hline P dentro de Goiano Precoce & 2 & 41,46751 & 20,73375 & $35,26 * *$ \\
\hline P dentro de Bolinha & 2 & 325,83583 & 162,91791 & $277,07 * \star$ \\
\hline P dentro de Carioca & 2 & 695,43251 & 347,71625 & $591,35 * \star$ \\
\hline P dentro de Rico 23 & 2 & 27,86082 & 13,93041 & $23,69 * *$ \\
\hline Cultivares dentro de $\mathrm{P}_{0}$ & 3 & 1207,41250 & 402,47083 & $684,47 * \star$ \\
\hline Cultivares dentro de $\mathrm{P}_{1}$ & 3 & 1406,69342 & 468,89780 & $797,44 * *$ \\
\hline Cultivares dentro de $\mathrm{P}_{2}$ & 3 & 2628,74123 & 876,24707 & $1490,21 * *$ \\
\hline D. dentro de Goiano Precoce & 1 & 2,22042 & 2,22042 & $3,77 \mathrm{~ns}$ \\
\hline D. dentro de Bolinha & 1 & 3,01042 & 3,01042 & $5,11 *$ \\
\hline D. dentro de Carioca & 1 & 2,40669 & 2,40669 & $4,09 *$ \\
\hline D. dentro de Rico 23 & 1 & 1,55043 & 1,55043 & $2,63 \mathrm{~ns}$ \\
\hline Cultivares dentro de $\mathrm{D}_{1}$ & 3 & 2302,61504 & 767,53834 & $1305,34 * \star$ \\
\hline Cultivares dentro de $\mathrm{D}_{2}$ & 3 & 2638,93237 & 879,64412 & $1495,99 * *$ \\
\hline Densidades dentro de $\mathrm{P}_{0}$ & 1 & 2,00000 & 2,00000 & $3,40 \mathrm{~ns}$ \\
\hline Densidades dentro de $\mathrm{P}_{1}$ & 1 & 1,66529 & 1,66529 & $2,83 \mathrm{~ns}$ \\
\hline Densidades dentro de $\mathrm{P}_{2}$ & 1 & 5,78002 & 5,78002 & $9,83 * \star$ \\
\hline $\mathrm{P}$ dentro de $\mathrm{D}_{1}$ & 2 & 424,70797 & 212,35398 & $361,14 * *$ \\
\hline $\mathrm{P}$ dentro de $\mathrm{D}_{2}$ & 2 & 364,84632 & 182,42316 & $310,24 * *$ \\
\hline
\end{tabular}

C.V. $\left(\frac{\circ}{\circ}\right)=2,49$

ns = não significativo

* = significativo à 5\%

** = significativo a $1 \%$ 
Os valores de $\mathrm{F}$ obtidos para doses de fósforo, para as interações cultivares $x$ doses de fósforo e doses de fósforo $x$ densidades, significativos ao nível de 18 de probabilidade, indicam que as doses de fósforo influíram na altura das plantas.

O valor de $F$ para densidades, não significativo, indica que isoladamente este parâmetro não influiu na altura das plantas; porém os valores de $\mathrm{F}$ para as interações cultivares $x$ densidades, doses de fósforo $x$ densidades e cultivares $\mathrm{x}$ doses de fósforo $\mathrm{x}$ densidades, significativos, mos tram que as densidades quando associadas a outro fator tive ram influência na altura das plantas.

Em face a esses resultados, foi feita uma análise detalhada das interações verificadas, estando a mesma contida na Tabela 2 .

o detalhamento das análises para a interação cultivares $\mathrm{x}$ doses de fósforo evidencia através dos valores de $\mathrm{F}$ obtidos para $\mathrm{P}$ dentro de $\mathrm{Cv}$, significativos, que em todas as cultivares as doses de fósforo influenciaram na altura das plantas. Por outro lado os valores de F para cultiva res dentro de $\mathrm{P}$, significativos, evidenciam que em todas as doses de fósforo as plantas das diferentes cultivares apresentaram variações significativas de altura.

o detalhamento das análises para a interação cultivares $\mathrm{x}$ densidades evidencia, através dos valores de $\mathrm{F}$ obtidos para D dentro de Bolinha e D dentro de Carioca, signi 
ficativos, que as densidades afetaram a altura das plantas nes tas cultivares. Os valores de F, significativos, para cultiva res dentro de $\mathrm{D}_{1}$ e cultivares dentro de $\mathrm{D}_{2}$ indicam que as cul tivares apresentaram diferenças siqnificativas de altura dentro de cada uma dessas densidades.

Com relação ao detalhamento das análises para a interação doses de fósforo x densidades, observa-se que o valor de $\mathrm{F}$ para densidades dentro de $\mathrm{P}_{2}$ foi significativo. Is to evidencia que as densidades afetaram significativamente a altura das plantas cultivadas com esta dose de fósforo, ou se ia, as plantas cultivadascom a dose de $150 \mathrm{~kg} / \mathrm{ha}$ de $\mathrm{P}_{2} \mathrm{O}_{5}$ tiveram suas alturas diferentes conforme as densidades. Por outro lado, os valores de $F$ obtidos para $P$ dentro de $D_{1}$ e $P$ dentro de $\mathrm{D}_{2}$, significativos, indicam que a altura das plantas den tro de cada densidade variou com a dose de fósforo.

Os dados contidos na Tabela 3 mostram as mëdias obtidas (cm) de altura de plantas para cultivares, doses de fósforo e densidades. A discriminação das médias atra vës do teste de Tukey apresentou a cultivar Carioca com (41.67 $\mathrm{cm})$, Rico $23(31,93 \mathrm{~cm})$, Bolinha $(27,23 \mathrm{~cm})$ e Goiano Precoce $(22,24 \mathrm{~cm})$ todas diferindo significativamente entre si. Com relacão a doses de fósforo, a discriminação das médias apresentou a dose $\mathrm{P}_{2} \operatorname{com} 31,87 \mathrm{~cm}, \mathrm{P}_{1} \operatorname{com} 26,95 \mathrm{~cm}$ e a dose $\mathrm{P}_{0}$ com 22,86 cm. todos diferindo significativamente entre si. Co mo se observa, as doses de fósforo causaram um incremento na altura das plantas, isto é, à medida que se aumentou o nível 
Tabela 3 - Altura de plantas (crm). Médias obtidas para as diferentes cultivares, doses de fósforo e densidades. Ilha Solteira, 1981.

\begin{tabular}{lcccc} 
Cultivares x Doses de Fösforo & $\mathrm{P}_{0}$ & $\mathrm{P}_{1}$ & $\mathrm{P}_{2}$ & DMS Tukey 5\% \\
\hline & 20,77 & 21,97 & 23,96 & Cv. den. $P=1,01$ \\
Goiano Precoce & 22,86 & 26,95 & 31,87 & \\
Bolinha & 36,12 & 39,93 & 48,96 & \\
Carioca & 30,63 & 31,87 & 33,27 & \\
Rico 23 & $30,=0,92$ \\
\hline
\end{tabular}

\begin{tabular}{lccl} 
Cultivares x Densidades & $D_{1}$ & $D_{2}$ & \\
\hline Goiano Precoce & 22,54 & 21,93 & Cv. den. $D=0,83$ \\
Bolinha & 27,58 & 26,87 & D den. Cv. $=0,63$ \\
Carioca & 41,35 & 41,99 & \\
Rico 23 & 32,18 & 31,67 &
\end{tabular}

Doses de Fósforo x Densidades $\quad D_{1} \quad D_{2}$

$\begin{array}{llll}\mathrm{P}_{0} & 27,85 & 27,35 & \mathrm{P} \text { den. } \mathrm{D}=0,65 \\ \mathrm{P}_{1} & 29,95 & 30,41 & \mathrm{D} \text { den. } \mathrm{P}=0,54 \\ \mathrm{P}_{2} & 34,94 & 34,09 & \end{array}$


de fósforo as plantas apresentaram maiores alturas.

Por outro lado, há de se mencionar que durante o ciclo da cultura ocorreram períodos bastante frios nos meses de iunho e julho, inclusive geada, o que provavelmente prejudicou o desenvolvimento das plantas, haja visto que os portes das mesmas foram relativamente baixos quando confrontados com resultados da literatura, que indicam portes bem mais altos para algumas destas cultivares, conforme SILVA (1981).

\subsection{Número DE VAgens POR PLANTA}

A análise de variância dos dados obtidos para nümero de vagens por planta encontra-se na Tabela 4. O valor de $F$ obtido para cultivares, significativo a $1 \%$, indica um comportamento diferente destas em relação a este parâmetro .

Os valores de $\mathrm{F}$ obtidos para doses de fósforo e para as inte rações cultivares $\mathrm{x}$. doses de fósforo e cultivares $\mathrm{x}$ doses de fósforo $x$ densidades indicam que os doses de fósforo influíram no número de vagens por planta. Os valores de F obtidos para densidades, significativos a 1\%, e para as intera cões cultivares $x$ densidades e cultivares $x$ doses de fósforo $\mathrm{x}$ densidades indicam que as densidades influíram no número de vagens por planta. O valor de $\mathrm{F}$ para a interação doses de fósforo x densidades, não significativo, indica que os efeitos destes fatores foram independentes dentro de uma mesma cul tivar, uma vez que se verificou interação significativa en- 
Tabela 4 - Nürnero de vagens por planta. Arálise da variância dos dados oḅ tidos.

\begin{tabular}{|c|c|c|c|c|}
\hline Causas de variação & G.L. & $S Q$ & QM & $F$ \\
\hline 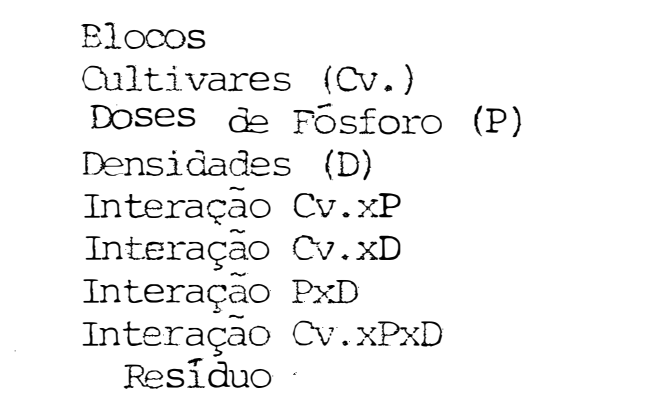 & $\begin{array}{r}3 \\
3 \\
2 \\
1 \\
6 \\
3 \\
2 \\
6 \\
69\end{array}$ & $\begin{array}{r}0,06125 \\
15,74375 \\
134,08145 \\
4,50667 \\
8,35437 \\
0,85082 \\
0,04770 \\
0,58479 \\
1,43874\end{array}$ & $\begin{array}{r}0,02041 \\
5,24791 \\
67,04072 \\
4,50667 \\
1,39239 \\
0,28360 \\
0,02385 \\
0,09746 \\
0,02085\end{array}$ & $\begin{array}{c}0,97 \mathrm{~ns} \\
251, \star \star \\
3215,16 \star \star \\
216,13 \star \star \\
66,77 \star \star \\
13,60 \star \star \\
1,14 \mathrm{~ns} \\
4,67 \star \star\end{array}$ \\
\hline TOTAL & 95 & 165,66958 & & \\
\hline $\begin{array}{l}\text { Doses de Eösforo" } \\
\text { Doses de Fösforo" }\end{array}$ & $\begin{array}{l}1 \\
1\end{array}$ & $\begin{array}{r}133,98062 \\
0,10083\end{array}$ & $\begin{array}{r}133,98062 \\
0,10083\end{array}$ & $\begin{array}{c}6425,49 \star \star \\
4,83 \star\end{array}$ \\
\hline $\begin{array}{l}\text { P dentro de Goiano Precoce } \\
\text { P dentro de Bolinha } \\
\text { P dentro de Carioca } \\
\text { P dentro de Rico } 23\end{array}$ & $\begin{array}{l}2 \\
2 \\
2 \\
2\end{array}$ & $\begin{array}{l}26,15083 \\
30,56083 \\
54,18083 \\
31,54333\end{array}$ & $\begin{array}{l}13,07541 \\
15,28041 \\
27,09041 \\
15,77166\end{array}$ & $\begin{array}{r}627,07 \star \star \\
732,82 * \star \\
1299,21 * \star \\
756,38 * \star\end{array}$ \\
\hline
\end{tabular}

Cultivares dentro de $\mathrm{P}_{0}$

$\begin{array}{rrrr}3 & 4,99093 & 1,66364 & 79,78 \star \star \\ 3 & 4,53125 & 1,51041 & 72,43 \star \star \\ 3 & 14,57593 & 4,85864 & 233,01 * \star\end{array}$

Cultivares dentro de $\mathrm{P}_{2}$

14,57593

,85864233,01**

\begin{tabular}{llllr} 
D. dentro de Goiano Precoce & 1 & 3,22666 & 3,22666 & $154,74^{\star *}$ \\
D. dentro de Bolinha & 1 & 0,32666 & 0,32666 & $15,66^{\star *}$ \\
D. dentro de Carioca & 1 & 1,17041 & 1,17041 & $56,13^{\star *}$ \\
D. dentro de Rico 23 & 1 & 0,63374 & 0,63374 & $30,39 * *$ \\
& & & & \\
\hline Cultivares dentro de $D_{1}$ & 3 & 9,19562 & 3,06520 & $147,00 * \star$ \\
Cultivares dentro de $D_{2}$ & 3 & 7,39895 & 2,46631 & $118,28 * \star$ \\
\hline
\end{tabular}

$$
\begin{aligned}
& C . V . \%=2,50 \\
& \mathrm{~ns}=\text { não significativo } \\
& \text { * = significativo a 5\% } \\
& \star \star ~=~ s i g n i f i c a t i v o ~ a ~ 1 \%
\end{aligned}
$$


tre cultivares $\mathrm{x}$ doses de fósforo $\mathrm{x}$ densidades, cultivares $\mathrm{x}$ doses de fósforo e cultivares $x$ densidades. Em face a estes resultados foi realizada uma anālise detalhada das interações verificadas, estando a mesma contida na Tabela 4.

o detalhamento das análises para doses de fósforo indica através dos valores F obtidos, significativos que o nümero de vagens por planta foi diferente tanto nas plantas cultivadas com a dose de 0 , como de 75 ou de $150 \mathrm{~kg}$ de $\mathrm{P}_{2} \mathrm{O}_{5}$, variando com cultivares e densidades.

O detalhamento das análises para a interação cultivares $\mathrm{x}$ doses de fósforo evidencia através dos valores de F obtidos para $P$ dentro das cultivares, significativos, que o nümero de vagens por planta dentro de cada uma das cultivares variou de acordo com a dose de fósforo. Por outro lado, os valores de F para cultivares dentro de P, significativos, indicam que dentro de cada uma das doses de fósforo o número de vagens por planta variou de cultivar para cultivar.

O detalhamento da interação cultivares $x$ densi dades evidencia através dos valores de F obtidos para densidades dentro de cultivares, significativos, que dentro de cada uma das cultivares, o número de vagens por planta variou de acordo com a densidade. Por outro lado os valores de F para cultivares dentro de densidades, significativos, indicam que as cultivares apresentaram diferentes números de vagens por planta dentro de cada uma das densidades utilizadas.

Na Tabela 5 estão contidos os dados referentes ao número de vagens por planta, com as médias obtidas para as 
Tabela 5 - Nümero de vagens por planta. Médias obtidas para as quatro cul tivares, doses de fósforo e densidades. Ilha Solteira, 1981.

\begin{tabular}{|c|c|c|c|c|}
\hline Cultivares x. Doses de Fósforo & $\mathrm{P}_{0}$ & $\mathrm{P}_{1}$ & $\mathrm{P}_{2}$ & DMS Tukey 5: \\
\hline Goiano Precoce & 4,46 & 5,57 & 7,01 & $C v \cdot$ den. $P=0,19$ \\
\hline Bolinha & 3,61 & 5,47 & 6,31 & $P$ den. $C v \cdot=0,17$ \\
\hline Carioca & 4,60 & 5,73 & 8,20 & \\
\hline Rico 23 & 4,48 & 6,43 & 7,21 & \\
\hline Cultivares x Densidades & $\mathrm{D}_{1}$ & & $\mathrm{D}_{2}$ & \\
\hline Goiano Precoce & 6,05 & & 5,31 & $C v \cdot$ den. $D=0,16$ \\
\hline Bolinha & 5,25 & & 5,01 & $\mathrm{D}$ den. Cv. $=0,12$ \\
\hline Carioca & 6,40 & & 5,95 & . \\
\hline Rico 23 & 6,20 & & 5,88 & \\
\hline Doses de Fósforo x Densidades & $\mathrm{D}_{1}$ & & $\mathrm{D}_{2}$ & \\
\hline $\mathrm{P}_{0}$ & 4,53 & & 4,04 & $P$ den. $D=0,12$ \\
\hline $\mathrm{P}_{1}$ & 6,00 & & 5,61 & $D$ den. $P=0,10$ \\
\hline$P_{2}$ & 7,39 & & 6,97 & \\
\hline
\end{tabular}


diferentes cultivares, doses de fósforo e densidades. Com a do se $\mathrm{P}_{0}$ as cultivares apresentaram um desempenho semelhante com apenas a cultivar Bolinha diferindo significativamente das de mais, apresentando um menor número de vagens por planta. Já com a dose $\mathrm{P}_{1}$ a cultivar Rico 23 apresentou o melhor desempenho dí ferindo significativamente das demais, sequida da Carioca que também diferiu siqnificativamente das cultivares Goiano Preco ce e Bolinha, as quais não diferiram entre si.

Com a dose $\mathrm{P}_{2}$ a cultivar Carioca apresentou um desempenho superior diferindo significativamente das demais, vindo a seguir as cultivares Rico 23, Goiano Precoce e Boli nha, sendo que todas diferiram significativamente entre si.

Nas cultivares, de uma inaneira geral, o nümero de vagens por planta variou decrescendo na seguinte ordem: Ca rioca, Rico 23, Goiano Precoce e Bolinha, sendo que com relaÇão a doses de fósforo, ' $\mathrm{P}_{2}$ semore foi superior às demais. Com relação às densidades, observou-se que na densidade maior as plantas sempre apresentaram um menor número de vacens por planta. Por outro lado, dentro de uma mesma densidade foi mais acentuado o aumento do número de vagens por planta à medida em que se aumentou a dose de fósforo, apesar que de um modo geral, à medida em que se aumentou a dose de fósforo houve aumento no número de vagens por planta. Os efeitos das densidades sobre o número de vagens por planta concordam com os resultados obtidos por SÁ et alii (1982) e VIDAL e JUNQUEIRA NE TO (1982) que observaram efeitos semelhantes de população so- 
bre o número de vagens por planta na cultura. Por outro lado, a diminuição no nümero de vagens por planta com o aumento da densidade concorda com os resultados obtidos por AGUDELO et. alie (1972), que relatam ser o número de vagens por planta o com ponente mais afetado pelas variações de população.

\subsection{Número de sementes por yagem}

A análise da variância do nümero de sementes por vagem encontra-se contida na Tabela 6. O valor de F obtido pa ra cultivares, significativo a $1 \frac{\circ}{8}$ de probabilidade, indica que as cultivares apresentaram número de sementes por vagem diferentes. Este fato é amplamente justificável haja visto queconforme descrito em VIEIRA (1978) as cultivares Goiano Precoce e Boli nha são do grupo Manteiga, Carioca do grupo Mulatinho e Rico 23 do grupo Preto, e conforme este autor geralmente as cultivares do grupo Manteiga apresentam menor número de sementes por vagem que cultivares de outros grupos. O valor de E, significa tivo,para doses de fósforo indica que as doses de fósforo a fetaram significativamente o número de sementes por vagem.

$\mathrm{Na}$ Tabela 7 estão contidas as médias obtidas para número de sementes por vagem para as três doses de adubação fosfatada com relação as cultivares e densidades. A dis criminação das médias através do teste de Tukey evidencia pạ ra a cultivar Goiano Precoce que as plantas cultivadas com 
$75 \mathrm{~kg}$ e $150 \mathrm{~kg} / \mathrm{ha}$ de $\mathrm{P}_{2} \mathrm{O}_{5}$ apresentaram nümero de sementes por vagem significativamente superior às plantas cultivadas sem a dubação. Já para as cultivares Bolinha e Rico 23, as plantas cultivadas com a dose mais elevada de adubação fosfatada produziram nümero de sementes por vagem significativamente superior ao das plantas cultivadas com as outras duas doses, enquanto que estas não diferiram entre si. Para a cultivar ca rioca observou-se diferença significativa apenas entre o nümero de sementes por vagem das plantas cultivadas com a dose de $150 \mathrm{~kg} / \mathrm{ha}$ de $\mathrm{P}_{2} \mathrm{O}_{5}$ em relação as cultivadas com a dose de 75 $\mathrm{kg} /$ ha de $\mathrm{P}_{2} \mathrm{O}_{5}$. Com relação às densidades, observa-se que tanto na densidade de 200.000 plantas como na densidade de 300.000 plantas/ha as plantas cultivadas com a dose de $150 \mathrm{~kg} / \mathrm{ha}$ de

Tabela 6 - Nümero de sementes por vagem. Análise da variância dos dados obtidos.

\begin{tabular}{|c|c|c|c|c|}
\hline Causas de variação & G.I. & $S Q$ & QM & $F$ \\
\hline Blocos & 3 & 0,27755 & 0,09251 & $1,36 \mathrm{~ns}$ \\
\hline Cultivares (Cv.) & 3 & 32,93550 & 10,97850 & $161,55^{\star \star}$ \\
\hline Doses de Fósforo (P) & 2 & 0,89502 & 0,44751 & $6,58 * \star$ \\
\hline Densidades (D) & 1 & 0,04420 & 0,04420 & $0,65 \mathrm{~ns}$ \\
\hline Interação Cv.xP & 6 & 0,29265 & 0,04877 & 0,71 ns \\
\hline Interação $\mathrm{Cv} \cdot \mathrm{xD}$ & 3 & 0,43914 & 0,14638 & $2,15 \mathrm{~ns}$ \\
\hline Interação PxD & 2 & 0,10552 & 0,05276 & $0,77 \mathrm{~ns}$ \\
\hline Interação CV.xPxD & 6 & 0,08617 & 0,01436 & $0,21 \mathrm{~ns}$ \\
\hline Resíduo & 69 & 4,69014 & 0,06797 & \\
\hline TOTAI & 95 & 39,76593 & & \\
\hline
\end{tabular}

C.V. $\frac{\circ}{0}=8,37$

ns = não significativo

* = significativo a $5 \%$

$\star \star$ = significativo a $1 \%$ 
Tabela 7 - Nümero de sementes por vagem. Médias obtidas para as quatro cultivares, doses de fósforo e densidades. Ilha Solteira, 1981.

\begin{tabular}{|c|c|c|c|c|}
\hline & \multicolumn{3}{|c|}{ Doses de fósforo } & \multirow[t]{2}{*}{ DMS TUKEY } \\
\hline & $P_{0}$ & $\mathrm{P}_{1}$ & $\mathrm{P}_{2}$ & \\
\hline Goiano Precoce & 2,21 & 2,40 & 2,45 & \multirow[t]{4}{*}{$P=0,16$} \\
\hline Bolinha & 2,63 & 2,61 & 2,92 & \\
\hline Carioca & 3,73 & 3,63 & 3,89 & \\
\hline Rico 23 & 3,60 & 3,50 & 3,71 & \\
\hline Densidades & $\mathrm{P}_{0}$ & $\mathrm{P}_{1}$ & $\mathrm{P}_{2}$ & DMS TUKEY \\
\hline$D_{1}$ & 3,07 & 3,01 & 3,30 & \multirow[t]{2}{*}{$P=0,15$} \\
\hline $\mathrm{D}_{2}$ & 3,02 & 3,01 & 3,18 & \\
\hline
\end{tabular}

$\mathrm{P}_{2} \mathrm{O}_{5}$ produziram número de sementes por vagem significativamen te superior ao das plantas cultivadas com as outras duas doses.

Na Tabela 8 estão contidos os valores obtidos para nümero de sementes por vagem das cultivares nos três níveis de adubação fosfatada e nas duas densidades de plantas. Observa-se que para uma mesma cultivar não se verificaram diferenças significativas entre as médias obtidas para nümero de sementes por vagem. 
Tabela 8 - Nümero de sementes por vagem. Médias obtidas para as quatro cultivares nos três níveis de adubação fosfatada e nas duas densidades de plantas. Ilha solteira, 1982.

\begin{tabular}{|c|c|c|c|c|c|}
\hline \multirow{3}{*}{$\frac{\text { Tratamentos }}{\mathrm{GPD}_{1} \mathrm{P}_{0}}$} & \multicolumn{4}{|c|}{ Blocos } & \multirow[b]{2}{*}{ Média* } \\
\hline & A & $\mathrm{B}$ & $\mathrm{C}$ & $\mathrm{D}$ & \\
\hline & 2,38 & 2,25 & 2,35 & 2,00 & 2,24 \\
\hline $\mathrm{GPD}_{2} \mathrm{P}_{0}$ & 2,02 & 2,53 & 2,20 & 2,00 & 2,18 \\
\hline $\mathrm{GPD}_{1} \mathrm{P}_{1}$ & 2,23 & 2,12 & 2,40 & 2,61 & 2,34 \\
\hline $\mathrm{GPD}_{2} \mathrm{P}_{2}$ & 2,68 & 2,54 & 2,54 & 2,11 & 2,46 \\
\hline $\mathrm{GPD}_{1} \mathrm{P}_{2}$ & 2,56 & 2,46 & 2,69 & 2,40 & 2,52 \\
\hline $\mathrm{GPD}_{2} \mathrm{P}_{2}$ & 2,65 & 2,74 & 2,07 & 2,09 & 2,38 \\
\hline $\mathrm{B} \mathrm{D}_{1} \mathrm{P}_{0}$ & 2,80 & 2,27 & 2,60 & 2,71 & 2,59 \\
\hline $\mathrm{B} \mathrm{D}_{2} \mathrm{P}_{0}$ & 3,00 & 2,43 & 2,80 & 2,50 & 2,68 \\
\hline $\mathrm{B} \mathrm{D}_{1} \mathrm{P}_{1}$ & 2,37 & 2,67 & 2,49 & 2,57 & 2,52 \\
\hline $\mathrm{B} \mathrm{D}_{2} \mathrm{P}_{1}$ & 2,55 & 2,80 & 2,76 & 2,73 & 2,71 \\
\hline $\mathrm{B} \mathrm{D}_{1} \mathrm{P}_{2}$ & 2,66 & 2,92 & 3,05 & 3,07 & $2,92 \quad b c$ \\
\hline $\mathrm{B} \mathrm{D}_{2} \mathrm{P}_{2}$ & 3,11 & 3,04 & 2,78 & 2,76 & $2,92 \quad b c$ \\
\hline $\mathrm{CD}_{1} \mathrm{P}_{0}$ & 4,08 & 3,47 & 3,94 & 3,18 & 3,66 a \\
\hline $\mathrm{C} \mathrm{D}_{2} \mathrm{P}_{0}$ & 3,93 & 3,55 & 3,72 & 4,00 & $3,80 \mathrm{a}$ \\
\hline $\mathrm{C} \mathrm{D}_{1} \mathrm{P}_{1}$ & 3,19 & 4,05 & 3,81 & 3,41 & $3,61 \mathrm{ab}$ \\
\hline $\mathrm{C} \mathrm{D}_{2} \mathrm{P}_{1}$ & 3,54 & 3,69 & 3,79 & 3,59 & $3,65 \mathrm{a}$ \\
\hline $\mathrm{C} \mathrm{D}_{1} \mathrm{P}_{2}$ & 3,41 & 4,17 & 4,28 & 3,89 & $3,93 \mathrm{a}$ \\
\hline $\mathrm{C} \mathrm{D}_{2} \mathrm{P}_{2}$ & 4,06 & 4,02 & 3,50 & 3,83 & $3,85 a$ \\
\hline $\mathrm{R} \mathrm{D}_{1} \mathrm{P}_{0}$ & 3,72 & 4,06 & 4,20 & 3,16 & 3,78 a \\
\hline $\mathrm{R} \mathrm{D}_{2} \mathrm{P}_{0}$ & 3,25 & 3,33 & 3,70 & 3,40 & $3,42 \mathrm{abc}$ \\
\hline $\mathrm{R} \mathrm{D}_{1} \mathrm{P}_{1}$ & 3,27 & 4,09 & 3,41 & 3,60 & $3,59 \mathrm{ab}$ \\
\hline $\mathrm{R} \mathrm{D}_{2} \mathrm{P}_{1}$ & 3,50 & 3,30 & 3,29 & 3,55 & $3,41 a b c$ \\
\hline $\mathrm{R} \mathrm{D}_{1} \mathrm{P}_{2}$ & 3,97 & 3,58 & 4,01 & 3,81 & $3,84 \mathrm{a}$ \\
\hline $\mathrm{R} \mathrm{D}_{2} \mathrm{P}_{2}$ & 3,24 & 3,60 & 3,68 & 3,84 & $3,59 \mathrm{ab}$ \\
\hline
\end{tabular}

* Mias de mesma letra não diferente significativamente entre si pelo teste de Tukey a 5응

GP - Goiano Precoce; B - Bolinha; C - Carioca; R - Rico 23

$\mathrm{D}_{1}=200.000$ plantas $/ \mathrm{ha} ; \mathrm{D}_{2}=300.000$ plantas $/ \mathrm{ha} ; \mathrm{P}_{0}=0 \mathrm{~kg} \mathrm{P}_{2} \mathrm{O}_{5} / \mathrm{ha}$

$\mathrm{P}_{1}=75 \mathrm{~kg} \mathrm{P} \mathrm{P}_{5} / \mathrm{ha} ; \mathrm{P}_{2}=150 \mathrm{~kg} \mathrm{P} \mathrm{P}_{5} / \mathrm{ha}$ 


\subsection{Produção de sementes}

A análise da variância dos dados obtidos para produção de sementes acha-se contida na Tabela 9 . O valor de F obtido para cultivares, altamente significativo, indica um comportamento diferente destas com relação à produção. Os valores de $\mathrm{F}$ obtidos para doses de fósforo e para cultivares $\mathrm{x}$ doses de fósforo indicam que os níveis de fósforo influíram na produção das cultivares. Os valores de F, significativos ao nível de 1 응 de probabilidade, para densidades, cultivares x densidades e doses de fósforo $\mathrm{x}$ densidaddes mostram que a produção nas cultivares foi diferente segundo a densidade, cul tivares e densidades e tambēm segundo as doses de fósforo e densidades.

Em face destes resultados foi feita a análise

detalhada das interações verificadas estando a mesma contida na Tabela 9 .

O detalhamento da interação cultivares $x$ do ses de fósforo evidencia através dos valores de F obtidospara $\mathrm{P}$ dentro das cultivares, significativos, que em cada cul tivar a produção foi diferente de acordo com a dose de fós foro utilizada. Por outro lado, os valores de F obtidos para cultiva res dentro de fósforo, significativos, indicam o comportamento diferencial de cada uma das cultivares dentro de uma dose de fósforo com relação a produção de sementes.

o detalhamento da interação cultivares x densí dades evidencia através dos valores de $F$ obtidos para $D$ den- 
Tabela 9 - Produção de sementes $(\mathrm{kg} / \mathrm{ha})$. Análise da variância dos dados obtidos.

\begin{tabular}{|c|c|c|c|c|}
\hline Causas de variação & G.L. & SQ & $a M$ & $F$ \\
\hline $\begin{array}{l}\text { Blocos } \\
\text { Cultivares (Cv.) } \\
\text { Doses, de Fösforo (P) } \\
\text { Densidades (D) } \\
\text { Interação Cv.xP } \\
\text { Interação Cv.xD } \\
\text { Interação PxD } \\
\text { Interação Cv.xPxD } \\
\text { Residuo }\end{array}$ & $\begin{array}{r}3 \\
3 \\
2 \\
1 \\
6 \\
3 \\
2 \\
6 \\
69\end{array}$ & $\begin{array}{r}35649,3 \\
1281868,6 \\
9153545,9 \\
3460168,2 \\
852262,9 \\
138917,8 \\
280599,0 \\
73856,8 \\
701479,8\end{array}$ & $\begin{array}{r}11883,1 \\
427289,5 \\
4576772,9 \\
3460168,2 \\
142043,8 \\
46305,9 \\
140299,5 \\
12309,4 \\
10166,3\end{array}$ & $\begin{array}{r}1,16 \mathrm{~ns} \\
42,02 \star \star \\
450,18^{\star \star} \\
340,35 \star \star \\
13,97 \star \star \\
4,55 \star \star \\
13,80 \star \star \\
1,21 \mathrm{~ns}\end{array}$ \\
\hline TOOTAL & 95 & 15978348,6 & & \\
\hline $\begin{array}{l}\text { Doses de Fósforo" } \\
\text { Doses de Fósforo" }\end{array}$ & $\begin{array}{l}1 \\
1\end{array}$ & $\begin{array}{r}9109584,0 \\
43962,0\end{array}$ & $\begin{array}{r}9109584,0 \\
43962,0\end{array}$ & $\begin{array}{c}896,05 \star \star \\
4,32 \star\end{array}$ \\
\hline $\begin{array}{l}\text { P dentro de Goiano Precoce } \\
\text { P dentro de Bolinha } \\
\text { P dentro de Carioca } \\
\text { P dentro de Rico } 23\end{array}$ & $\begin{array}{l}2 \\
2 \\
2 \\
2\end{array}$ & $\begin{array}{l}1821135,3 \\
2226555,7 \\
4757542,2 \\
1200575,5\end{array}$ & $\begin{array}{r}910567,6 \\
1113277,8 \\
2378771,1 \\
600287,7\end{array}$ & $\begin{array}{r}89,56 * \star \\
109,50 * \star \\
233,98 * \star \\
59,04 * \star\end{array}$ \\
\hline $\begin{array}{l}\text { Cultivares dentro de } \mathrm{P}_{0} \\
\text { Cultivares dentro de } \mathrm{P}_{1} \\
\text { Cultivares dentro de } \mathrm{P}_{2}\end{array}$ & $\begin{array}{l}3 \\
3 \\
3\end{array}$ & $\begin{array}{r}115661,2 \\
107393,9 \\
1911076,4\end{array}$ & $\begin{array}{r}38553,7 \\
35797,9 \\
637025,4\end{array}$ & $\begin{array}{l}3,79 \star \\
3,52 \star \\
62,66 \star \star\end{array}$ \\
\hline $\begin{array}{l}\text { D. dentro de Goiano Precoce } \\
\text { D. dentro de Bolinha } \\
\text { D. dentro de Carioca } \\
\text { D. dentro de Rico } 23\end{array}$ & $\begin{array}{l}1 \\
1 \\
1 \\
1\end{array}$ & $\begin{array}{r}604787,2 \\
1277750,4 \\
1207631,2 \\
507917,2\end{array}$ & $\begin{array}{r}605787,2 \\
1277750,4 \\
1207631,2 \\
507917,2\end{array}$ & $\begin{array}{r}59,58 * \star \\
125,68 * \star \\
118,78 * \star \\
49,96 * \star\end{array}$ \\
\hline $\begin{array}{l}\text { Cultivares dentro de } D_{1} \\
\text { Cultivares dentro de } D_{2}\end{array}$ & $\begin{array}{l}3 \\
3\end{array}$ & $\begin{array}{r}385477,3 \\
1305309,0\end{array}$ & $\begin{array}{l}128492,4 \\
345103,0\end{array}$ & $\begin{array}{l}12,63 \star \star \\
33,94 * \star\end{array}$ \\
\hline $\begin{array}{l}\text { Densidades dentro de } \mathrm{P}_{0} \\
\text { Densidades dentro de } \mathrm{P}_{1} \\
\text { Densidades dentro de } \mathrm{P}_{2}\end{array}$ & $\begin{array}{l}1 \\
1 \\
1\end{array}$ & $\begin{array}{r}438506,7 \\
1357725,3 \\
1944535,0\end{array}$ & $\begin{array}{r}438506,6 \\
1357725,3 \\
1944535,0\end{array}$ & $\begin{array}{r}43,13 \star \star \\
133,55 \star \star \\
191,27 \star \star\end{array}$ \\
\hline $\begin{array}{l}\mathrm{P} \text { dentro de } \mathrm{D}_{1} \\
\mathrm{P} \text { dentro de } \mathrm{D}_{2}\end{array}$ & $\begin{array}{l}2 \\
2\end{array}$ & $\begin{array}{l}3177704,2 \\
6256440,7\end{array}$ & $\begin{array}{l}1588852,1 \\
3128220,3\end{array}$ & $\begin{array}{l}156,28 * \star \\
307,70 * \star\end{array}$ \\
\hline
\end{tabular}

C.V. $\left(\frac{\circ}{0}\right)=8,40$

ns = não significativo

* = significativo à $5 \%$

$\star \star$ = significativo a 18 
tro de cultivares, que as densidades influíram significativamente na produção de cada cultivar. Por outro lado, os valores de F, significativos, obtidos para $\mathrm{CV}$. dentro de $\mathrm{D}$ indicam que houve diferenças nas produções das cultivares dentro de cada uma das densidades.

O detalhamento da interação $\mathrm{P} \times \mathrm{D}$, evidencia $\underline{\mathrm{a}}$ través dos valores de F, significativos, obtidos para D dentro de $\mathrm{P}$ que as densidades influíram significativamente na pro dução de sementes das cultivares cultivadas em cada dose de fósfo ro Já os valores de. F; significativos, para P dentro de $D$, indicam que as doses de fósforo influíram na prodū ção das cultivares tanto na densidade de 200.000 como na de 300.000 plantas/ha.

Os dados obtidos para produção (kg/ha) com as médias para as diferentes cultivares, doses de fósforo e densidades estão contidos na Tabela 10. Observa-se que com a dose $\mathrm{P}_{0}$ a produção da cultivar Carioca foi significativamente supe rior a da cultivar Rico 23 porém não diferindo: das demais. que também não apresentaram diferenças significativas entre si. Já com a dose $\mathrm{P}_{1}$ se observou um melhor comportamento da cultivar Rico 23, enquanto que as demais não diferiram significativamente entre si.

com a-dose $\mathrm{P}_{2}$, $150 \mathrm{~kg} / \mathrm{ha}$ de $\mathrm{P}_{2} \mathrm{O}_{5}$, observou-se uma produção de sementes significativamente superior para a cultivar Carioca em relação às demais, enquanto que as cultivares Bolinha e Goiano Precoce apresentaram produções estatis 
ticamente semelhantes porém significativamente superiores à produção da cultivar Rico 23 .

Em todas as cultivares a dose de $150 \mathrm{~kg} / \mathrm{ha}$ de $\mathrm{P}_{2} \mathrm{O}_{5}$ sempre ocasionou maiores produções, que diferiram significativamente das produções das cultivares com as outras doses Também a dose de $75 \mathrm{~kg} / \mathrm{ha}$ de $\mathrm{P}_{2} \mathrm{O}_{5}$ sempre ocasionou acrésci mos significativos nas produções das cultivares em relação a dose de $0 \mathrm{~kg} / \mathrm{ha}$ de $\mathrm{P}_{2} \mathrm{O}_{5}$.

Os efeitos das doses de fósforo e densidades na produção das cultivares estão ilústrados na Figura 1, a qual foi feita em função dos dados médios obtidos no experi mento que estão contidos no Apêndice 1.

Na densidade de 300.000 plantas/ha e com uma mesma de fósforo as cultivares sempre apresentaram maiores pro duções do que na densidade de 200.000 plantas/ha.

Há de se ressaltar que durante o ciclo da cultura houve ocorrência de oídio e crestamento bacteriano comum, doenças essas que foram prontamente controladas, sendo que o crestamento bacteriano apareceu já nofinal de ciclo das plantas, de forma que esta doença não chegou a prejudicar seriamente a cultura.

A produção foi avali̇ada com as sementes apre sentando $10 \%$ de umidade, haja visto que na época em que se rea lizaram as avaliações o teor de umidade das sementes foi determinado com todas as amostras apresentando teores ao redor de $10 \%$ 
Tabela 10 - Produção de sementes $(\mathrm{kg} / \mathrm{ha}$ ). Médias obtidas para as quatro cultivares, doses de fósforo e densidades. Ilha Solteira,1981.

Cultivares $x$ Doses de Fósforo $\quad \mathrm{P}_{0} \quad \mathrm{P}_{1} \quad \mathrm{P}_{2} \quad$ Dims Tukey 5\%

Goiano Precoce

Bolinha

Carioca

Pico 23
841,77 1176,00 1516,51 Cv.den.P.=133,05

$821,09 \quad 1222,67 \quad 1566,43$

$927,63 \quad 1205,721979,93$

$759,74 \quad 1073,361305,57$

$\begin{array}{lrrr}\text { Cultivares x Densidades } & \mathrm{D}_{1} & \mathrm{D}_{2} & \\ \text { Goiano Precoce } & 1019,22 & 1336,97 & \text { Cv.den. }=108,56 \\ \text { Bolinha } & 972,66 & 1434,14 & \text { D den. Cv. }=82,37 \\ \text { Carioca } & 1146,78 & 1595,41 & \\ \text { Rico 23 } & 900,75 & 1191,70 & \end{array}$

\begin{tabular}{crrr} 
Doses: de Fósforo x Densidades & $\mathrm{D}_{1}$ & $\mathrm{D}_{2}$ \\
\hline $\mathrm{P}_{0}$ & 720,50 & 954,62 & $\mathrm{P}$ den. $\mathrm{D}=85,44$ \\
$\mathrm{P}_{1}$ & 963,46 & 1375,42 & $\mathrm{D}$ den. $\mathrm{P}=71,33$ \\
$\mathrm{P}_{2}$ & 1345,60 & 1838,62 &
\end{tabular}




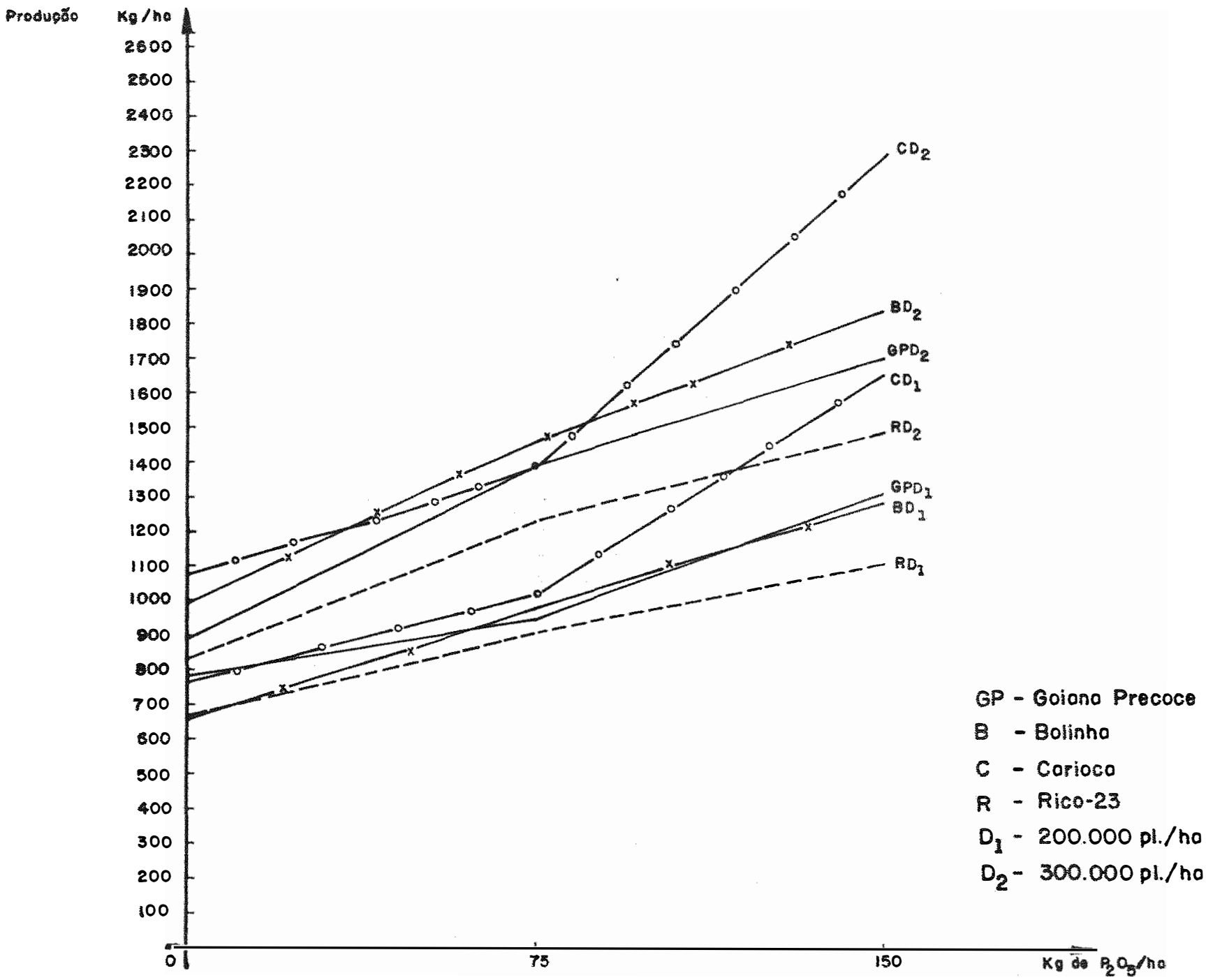

Figura 1 - Efeitos de doses de fósforo na produção de 4 cultivares de feijão cultivados em 2 densidade de plantas. Ilha soltei ra, 1981. 
Em termos de produção de sementes, para todas as cultivares a melhor combinação observada para doses de fósforo e densidades foi $150 \mathrm{~kg} / \mathrm{ha}$ de $\mathrm{P}_{2} \mathrm{O}_{5}$ e 300.000 Plantas/ /ha.

\subsection{Peso DE MIL Sementes}

A análise da variância dos dados obtidos para peso de mil sementes está contida na Tabela ll. O valor de F para cultivares, significativo, indica que o peso de mil sementes foi diferente entre as sementes das cultivares. Fato este plenamente justificável uma vez que as cultivares perten cem a grupos diferentes, conforme VIEIRA (1978), apresentando diferentes tamanhos e portanto diferentes pesos.

Os valores de F para doses de fósforo, para as interações cultivares $x$ níveis de fósforo e doses de fósforo $x$ densidades, altamente significativos, indicam que os doses de fósforo influíram no peso de mil sementes das culti vares, e que este variou conforme as doses de fósforo, culti vares e.doses de fósforo, e níveis de fósforo e densidades. Os valores de F obtidos para densidades e para as interações cultivares $\mathrm{x}$ densidades e doses de fósforo $\mathrm{x}$ densidades, sig nificativos, indicam que o peso de mil sementes nas cultiva res foi diferente segundo as densidades, cultivares e densida des e também segundo as doses de fósforo e densidades.

Em face destes resultados, foi feita a anālise detalhada das interações verificadas, estando a mesma contida 
Tabela 11 - Peso de mil sementes ( $g$ ). Análise da variância dos dados obti dos.

\begin{tabular}{|c|c|c|c|c|}
\hline Causas de variação & G.I. & SQ & gis & $F$ \\
\hline $\begin{array}{l}\text { Blocos } \\
\text { Cultivares (Cv.) } \\
\text { Doses de Fósforo (P) } \\
\text { Densidades (D) } \\
\text { Interação Cv.xP } \\
\text { Interação } \mathrm{CV} \cdot x \mathrm{D} \\
\text { Interação PxD } \\
\text { Interação Cv.xPXD } \\
\text { Residuo }\end{array}$ & $\begin{array}{r}3 \\
3 \\
2 \\
1 \\
6 \\
3 \\
2 \\
6 \\
69\end{array}$ & $\begin{array}{r}3,3 \\
447620,1 \\
2280,0 \\
12,0 \\
2840,2 \\
33,7 \\
28,0 \\
113,0 \\
68,1\end{array}$ & $\begin{array}{r}1,1 \\
149206,7 \\
1140,0 \\
12,0 \\
473,3 \\
11,2 \\
14,0 \\
18,8 \\
0,9\end{array}$ & $\begin{array}{r}1,14 \mathrm{~ns} \\
165785,22 * \star \\
1154,78 * \star \\
12,20 * \star \\
479,49 * \star \\
11,40 * \star \\
14,22 * \star \\
19,09 * \star\end{array}$ \\
\hline TOTAE & 95 & & & \\
\hline $\begin{array}{l}\text { Doses de Fósforo" } \\
\text { Doses de Fösforo" }\end{array}$ & $\begin{array}{l}1 \\
1\end{array}$ & $\begin{array}{r}2280,0 \\
0,0\end{array}$ & $\begin{array}{r}2280,0 \\
0,0\end{array}$ & $\begin{array}{r}2309,54 * \star \\
0,02 \mathrm{~ns}\end{array}$ \\
\hline $\begin{array}{l}\text { P dentro de Goiano Precoce } \\
\text { P dentro de Bolinha } \\
\text { P dentro de Carioca } \\
\text { P dentro de Rioo } 23\end{array}$ & $\begin{array}{l}2 \\
2 \\
2 \\
2\end{array}$ & $\begin{array}{r}177,3 \\
4,0 \\
4810,7 \\
128,2\end{array}$ & $\begin{array}{r}88,6 \\
2,0 \\
2405,3 \\
64,1\end{array}$ & $\begin{array}{r}89,81 * \star \\
2,02 \text { ns } \\
2436,47 \star \star \\
64,95 * \star\end{array}$ \\
\hline $\begin{array}{l}\text { Cultivares dentro de } \mathrm{P}_{0} \\
\text { Cultivares dentro de } \mathrm{P}_{1} \\
\text { Cultivares dentro de } \mathrm{P}_{2}\end{array}$ & $\begin{array}{l}3 \\
3 \\
3\end{array}$ & $\begin{array}{l}162505,0 \\
150512,7 \\
137442,6\end{array}$ & $\begin{array}{l}54168,3 \\
50170,9 \\
45814,2\end{array}$ & $\begin{array}{l}54868,79 * \star \\
50819,68 * \star \\
46406,63 * \star\end{array}$ \\
\hline $\begin{array}{l}\text { D. dentro de Goiano Precoce } \\
\text { D. dentro de Bolinha } \\
\text { D. dentro de Carioca } \\
\text { D. dentro de Rico } 23\end{array}$ & $\begin{array}{l}1 \\
1 \\
1 \\
1\end{array}$ & $\begin{array}{r}4,1 \\
1,5 \\
37,4 \\
2,6\end{array}$ & $\begin{array}{r}4,1 \\
1,5 \\
37,4 \\
2,6\end{array}$ & $\begin{array}{l}4,22 * \\
1,5 \operatorname{lns} \\
37,98 * \star \\
2,70 \mathrm{~ns}\end{array}$ \\
\hline $\begin{array}{l}\text { Cultivares dentro de } D_{1} \\
\text { Cultivares dentro de } D_{2}\end{array}$ & $\begin{array}{l}3 \\
3\end{array}$ & $\begin{array}{l}221371,5 \\
226282,4\end{array}$ & $\begin{array}{l}73790,5 \\
75497,4\end{array}$ & $\begin{array}{l}74744,69 \star \star \\
76402,83 \star \star\end{array}$ \\
\hline $\begin{array}{l}\text { Densidades dentro de } \mathrm{P}_{0} \\
\text { Densidades dentro de } \mathrm{P}_{1} \\
\text { Densidades dentro de } \mathrm{P}_{2}\end{array}$ & $\begin{array}{l}1 \\
1 \\
1\end{array}$ & $\begin{array}{r}2,0 \\
2,0 \\
36,1\end{array}$ & $\begin{array}{r}2,0 \\
2,0 \\
36,1\end{array}$ & $\begin{array}{r}2,02 \mathrm{~ns} \\
2,02 \mathrm{~ns} \\
36,59 \star *\end{array}$ \\
\hline $\begin{array}{l}\text { P dentro de } D_{1} \\
P \text { dentro de } D_{2}\end{array}$ & $\begin{array}{l}2 \\
2\end{array}$ & $\begin{array}{r}1308,6 \\
999,5\end{array}$ & $\begin{array}{l}654,3 \\
499,7\end{array}$ & $\begin{array}{l}662,79 * * \\
506,21 * *\end{array}$ \\
\hline
\end{tabular}

C.V. $\left(\frac{\circ}{0}\right)=0,35$

ns = não significativo

* = significativo à 5\%

$\star *$ = significativo a 1 응 
na Tabela 11.

O detalhamento da análise para doses de fósforo evidencia que apenas as plantas produzidas com umadas do ses produziram sementes com peso de mil sementes significativamente diferente dos pesos de mil sementes das plantas culti vadas com as outras duas doses.

O detalhamento da interação cultivares $x$ doses de fósforo evidenciou que os níveis de fósforo apenas não afetaram significativamente o peso de mil sementes da cul tivar Bolinha, uma vez que o valor de $F$ para $P$ dentro de Boli nha foi não significativo. No entanto os valores de F, significativos, para cultivares dentro de $\mathrm{P}_{0}, \mathrm{P}_{1}$ e $\mathrm{P}_{2}$, evidenciam que as sementes das diversas cultivares apresentaram peso de mil sementes significativamente diferentes tanto para as plan tas cultivadas com $0 \mathrm{~kg}$ como com $75 \mathrm{~kg}$ ou $150 \mathrm{~kg} / \mathrm{ha}$ de $\mathrm{P}_{2} \mathrm{O}_{5}$.

Com relação aos valores de $\mathrm{F}$ obtidos para Densidades dentro de cultivares, observa-se que os valores de $F$ obtidos para D dentro de Goiano Precoce e D dentro de Carioca, significativos, indicam que as densidades de plantas afetaram o peso de mil sementes destas duas cultivares significa tivamente. Por outro lado, os valores de F, significativos, pa ra cultivares dentro de $\mathrm{D}_{1}$ e cultivares dentro de $\mathrm{D}_{2}$ eviden ciam que os pesos de mil sementes das cultivares foram significativamente diferentes dentro de cada uma das densidades.

$O$ valor de $F$ obtido para $D$ dentro de $\mathrm{P}_{2}$, altamente significativo, indica que as densidades afetaram signi- 
Tabela 12 - Peso de mil senentes (g). Médias obtidas para diferentes cultivares, doses de fósforo e densidades. Ilha Solteira, 1981.

Cultivares $x$. Doses, de Fósforo $\quad P_{0} \quad P_{1} \quad P_{2}$ DNs Tukey $5 q$

Goiano Precoce

Bolinha

Carioca

Rico 23

$$
\begin{array}{llll}
350,25 & 354,75 & 356,75 & \text { Cv.den.P }=1,31 \\
342,50 & 343,00 & 343,50 & \text { P den.CV. }=1,19 \\
218,00 & 233,62 & 252,62 \\
192,25 & 195,62 & 197,87
\end{array}
$$

\begin{tabular}{|c|c|c|c|}
\hline Cultivares x Densidades & $\mathrm{D}_{1}$ & $\mathrm{D}_{2}$ & \\
\hline Goiano Precoce & 353,50 & 354,33 & $C v \cdot$ den. $D=1,03$ \\
\hline Bolinha & 343,25 & 342,75 & $\mathrm{D}$ den. $\mathrm{Cv} .=0,78$ \\
\hline Carioca & 236,00 & 233,50 & \\
\hline Rico 23 & 195,58 & 194,91 & \\
\hline Doses de Fösforo x Densidades & $\mathrm{D}_{1}$ & $\mathrm{D}_{2}$ & \\
\hline $\mathrm{P}_{0}$ & 276,00 & 275,50 & $P$ den. $D=0,81$ \\
\hline$P_{1}$ & 281,50 & 282,00 & $D$ den. $P=0,68$ \\
\hline $\mathrm{P}_{2}$ & 288,75 & 286,62 & \\
\hline
\end{tabular}


ficativamente o peso de mil sementes das cultivares cultivadas com esta dose de fósforo. Por outro lado, os valores de $F$, significativos, para $\mathrm{P}$ dentro de $\mathrm{D}_{1}$ e $\mathrm{P}$ dentro de $\mathrm{D}_{2}$, indicam que as do ses de fósforo afetaram o peso de mil sementes tanto na den sidade de 200.000 como na de 300.000 plantas/ha.

Os dados obtidos para peso de mil sementes nas diversas cultivares, doses de fósforo e densidades, estão contidos na Tabela 12. Observa-se que as cultivares apresentaram pesos de mil sementes significativamente diferentes de acordo com a dose de fósforo, com médias de 353 g, 343 g, $234 \mathrm{~g}$ e 195 g respectivamente para Goiano Precoce, Bolinha, Carioca e Rico 23

Nas cultivares Goiano Precoce, Carioca e Rico 23 observou-se um incremento significativo das doses de fósforo no peso de mil sementes com os efeitos sendo crescentes com äs doses de fósforo.

Na cultivar Carioca as densidades afetaram sig nificativamente o peso de mil sementes o qual foi maior na den sidade de 200.000 plantas do que na de 300.000 plantas/ha.

\subsection{Porcentagem de germinação}

A análise da variância dos dados obtidos pará porcentagem de germinação das sementes das 4 cultivares acha-se contida na Tabela 13. O valor de F para cultivares, signi ficativo a l\% de probabilidade, indica que as sementes das dí 
ferentes cultivares apresentaram porcentagens de geminação diferentes. O valor de $F$ para doses de fósforo significativo, indica que as doses de fósforo influíram na porcentagem de germinação das sementes das cultivares. A não verificação de interação entre cultivares e doses de fósforo indica que os efeitos destes parâmetros na germinação das sementes foram in dependentes.

Tabela 13 - Porcentagen de genninação. Análise da variância dos dados obtidos.

\begin{tabular}{lrrrc}
\hline Causas de variação & G.L. & SQ & CM & $F$ \\
\hline Blocos & 3 & 74,11083 & 24,70361 & $2,35 \mathrm{~ns}$ \\
Cultivares (Cv.) & 3 & 1936,91968 & 645,63989 & $61,62 \star \star$ \\
Doses, de Fösforo (P) & 2 & 151,44751 & 75,72375 & $7,22 \star \star$ \\
Densidades (D) & 1 & 0,39819 & 0,39819 & $0,03 \mathrm{~ns}$ \\
Interação CV.xP & 6 & 32,64794 & 5,44132 & $0,51 \mathrm{~ns}$ \\
Interação Cv.xD & 3 & 67,16186 & 22,38728 & $2,13 \mathrm{~ns}$ \\
Interação PxD & 2 & 6,54003 & 3,27001 & $0,31 \mathrm{~ns}$ \\
Interação CV.xPxD & 6 & 48,49536 & 8,08256 & $0,77 \mathrm{~ns}$ \\
$\quad$ Residuo & 69 & 722,96533 & 10,47775 & \\
\hline Tolat & 95 & 3040,68677 & & \\
\hline
\end{tabular}

C.V. $\frac{\circ}{\circ}=4,06$

ns $=$ não significativo

$* *=$ significativo a $1 \%$ 
Na Tabela 14 encontram-se contidas as médias obtidas para porcentagem de germinação das sementes (dados transformados em arc sen $\sqrt{\text { 임이 }}$, das diferentes cultivares, em relação a doses de fósforo e cultivares e doses de fósforo e densidades.

Tabela 14 - Porcentagem de germinação. Médias obtidas para as doses de fósforo en relação às quatro cultivares e densidades. Ilha Solteira, 1981.

\begin{tabular}{|c|c|c|c|c|}
\hline \multirow{2}{*}{ Cultivares } & \multicolumn{3}{|c|}{ Doses de fósforo } & \multirow{2}{*}{ DMS TUKEY 5\% } \\
\hline & $P_{0}$ & $\mathrm{P}_{1}$ & $\mathrm{P}_{2}$ & \\
\hline Goiano Precoce & 73,63 & 72,90 & 74,72 & \multirow{4}{*}{$P=1,94$} \\
\hline Bolinha & 75,30 & 75,91 & 79,33 & \\
\hline Carioca & 79,83 & 80,85 & 83,47 & \\
\hline Rico 23 & 83,90 & 85,93 & 86,95 & \\
\hline Densidades & \multicolumn{3}{|c|}{ Doses de fósforo } & DMS TUKEY 5\% \\
\hline & $\mathrm{P}_{0}$ & $\mathrm{P}_{1}$ & $\mathrm{P}_{2}$ & \\
\hline$D_{1}$ & 78,02 & 78,56 & 81,41 & $P=1,94$ \\
\hline $\mathrm{D}_{2}$ & 78,31 & 79,23 & 80,83 & \\
\hline
\end{tabular}

Observa-se para as cultivares Goiano Precoce, Bolinha e Carioca não ocorreram diferenças significativas na porcentagem de germinação de sementes oriundas de plantas cul tivadas com as doses de $0 \mathrm{~kg}$ e $75 \mathrm{~kg} / \mathrm{ha}$ de $\mathrm{P}_{2} \mathrm{O}_{5}$. No entanto sementes das cultivares Carioca e Bolinha, originadas de plantas cultivadas com a dose de $150 \mathrm{~kg} / \mathrm{ha}$ de $\mathrm{P}_{2} \mathrm{O}_{5}$ apresentaram porcentagem de germinação significativamente superior às se- 
mentes das plantas cultivadas com as outras duas doses. Para a. cultivar Rico 23, as sementes das plantas cultivadas com as doses $\mathrm{P}_{1}$ e $\mathrm{P}_{2}$ apresentaram porcentagem de germinação significativamente superior às das plantas cultivadas com a dose $\mathrm{P}_{0}$. Com relação às densidades, verificou-se um com portamento superior das sementes das plantas cultivadas com a dose $\mathrm{P}_{2}$ na densidade de 200.000 plantas em relação às semen tes das plantas cultivadas com as outras duas doses. Jána den sidade de 300.000 plantas observou-se uma maior porcentagem de germinação das sementes de plantas cultivadas com as doses de 75 e $150 \mathrm{~kg} / \mathrm{ha}$ de $\mathrm{P}_{2} \mathrm{O}_{5}$ em relação a $0 \mathrm{~kg} / \mathrm{ha}$ de $\mathrm{P}_{2} \mathrm{O}_{5}$.

Por outro lado, observou-se diferenças no comportamento das cultivares com relação a este parâmetro analisado dando-se a entender que os efeitos verificados não podem ser atribuídos unicamente à fertilização fosfatada e às densi dades de plantas.

Na Tabela 15 estão contidos os dados obtidos para porcentagem de germinação, de acordo com os tratamentos utilizados. Observa-se que dentro de uma mesma cultivar nãose observou diferença significativa entre os tratamentos e que as diferenças ocorreram apenas entre as sementes das diferentes cultivares. 
Tabela 15 - Porcentagem de germinação de sementes de 4 cultivares de feijão cultivadas em três doses de adubação fosfatada e 2 densidades de plantas (dados transformados em arc sen $\sqrt{8 / 100}$ ). I lha Solteira, 1982.

\begin{tabular}{|c|c|c|c|c|c|}
\hline \multirow{2}{*}{ Tratamentos } & \multicolumn{4}{|c|}{ Blocos } & \multirow{2}{*}{ Média* } \\
\hline & A & B & C & $\mathrm{D}$ & \\
\hline$G D_{1} P_{0}$ & 73,57 & 73,57 & 75,82 & 71,57 & 73,63 \\
\hline $\mathrm{GPD}_{2} \mathrm{P}_{0}$ & 71,57 & 73,57 & 75,82 & 73,57 & 73,63 \\
\hline $\mathrm{GPD}_{1} \mathrm{P}_{1}$ & 71,57 & 73,57 & 71,57 & 73,57 & 72,57 \\
\hline $\mathrm{GPD}_{2} \mathrm{P}_{1}$ & 75,82 & 75,82 & 69,73 & 71,57 & $73,23 \mathrm{~cd}$ \\
\hline $\mathrm{GPD}_{1} \mathrm{P}_{2}$ & 75,82 & 73,57 & 75,82 & 75,82 & $75,25 \mathrm{bcd}$ \\
\hline $\mathrm{GPD}_{2} \mathrm{P}_{2}$ & 71,57 & 75,82 & 73,57 & 75,82 & $74,19 \mathrm{bcd}$ \\
\hline $\mathrm{B} \mathrm{D}_{1} \mathrm{P}_{0}$ & 75,82 & 73,57 & 75,82 & 75,82 & $75,25 \mathrm{bcd}$ \\
\hline $\mathrm{B} \mathrm{D}_{2} \mathrm{P}_{0}$ & 73,57 & 78,46 & 73,57 & 75,82 & $75,35 \mathrm{bcd}$ \\
\hline $\mathrm{B} \mathrm{D}_{1} \mathrm{P}_{1}$ & 75,82 & 78,46 & 73,57 & 75,82 & 75,91 bcd \\
\hline $\mathrm{B} \mathrm{D}_{2} \mathrm{P}_{1}$ & 73,57 & 75,82 & 75,82 & 78,46 & $75,91 \mathrm{bcd}$ \\
\hline $\mathrm{B} \mathrm{D}_{1} \mathrm{P}_{2}$ & 75,82 & 90,00 & 75,82 & 75,82 & $79,36 \mathrm{abcd}$ \\
\hline $\mathrm{B} \mathrm{D}_{2} \mathrm{P}_{2}$ & 78,46 & 81,87 & 78,46 & 78,46 & $79,31 \mathrm{abcd}$ \\
\hline$C D_{1} P_{0}$ & 81,87 & 78,46 & 78,46 & 78,46 & $79,31 \mathrm{abcd}$ \\
\hline$C D_{2} P_{0}$ & 75,82 & 81,87 & 81,87 & 81,87 & $80,35 \mathrm{abcd}$ \\
\hline$C D_{1} P_{1}$ & 75,82 & 78,46 & 78,46 & 78,46 & $77,80 \mathrm{bcd}$ \\
\hline $\mathrm{C} \mathrm{D}_{2} \mathrm{P}_{1}$ & 81,87 & 90,00 & 81,87 & 81,87 & $83,90 \mathrm{ab}$ \\
\hline$C \mathrm{D}_{1} \mathrm{P}_{2}$ & 78,46 & 90,00 & 81,87 & 81,87 & $83,05 \mathrm{abc}$ \\
\hline $\mathrm{C} \mathrm{D}_{2} \mathrm{P}_{2}$ & 90,00 & 81,87 & 81,87 & 81,87 & $83,90 \mathrm{ab}$ \\
\hline $\mathrm{R} \mathrm{D}_{1} \mathrm{P}_{0}$ & 81,87 & 90,00 & 81,87 & 81,87 & $83,90 \mathrm{ab}$ \\
\hline $\mathrm{R} \mathrm{D}_{2} \mathrm{P}_{0}$ & 81,87 & 81,87 & 81,87 & 90,00 & $83,90 \mathrm{ab}$ \\
\hline $\mathrm{R} \mathrm{D}_{1} \mathrm{P}_{1}$ & 90,00 & 90,00 & 90,00 & 81,87 & $87,96 \mathrm{a}$ \\
\hline $\mathrm{R} \mathrm{D}_{2} \mathrm{P}_{1}$ & 81,87 & 81,87 & 81,87 & 90,00 & $83,90 \mathrm{ab}$ \\
\hline $\mathrm{R} \mathrm{D}_{1} \mathrm{P}_{2}$ & 90,00 & 81,87 & 90,00 & 90,00 & $87,96 \mathrm{a}$ \\
\hline $\mathrm{R} \mathrm{D}_{2} \mathrm{P}_{2}$ & 81,87 & 90,00 & 90,00 & 81,87 & $85,93 \mathrm{ab}$ \\
\hline
\end{tabular}

* Médias seguidas de mesma letra não diferem significativamente entre si pelo teste de Tukey a 5\%.

GP - Goiano Precoce; B - Bolinha; C - Carioca; R - Rico 23

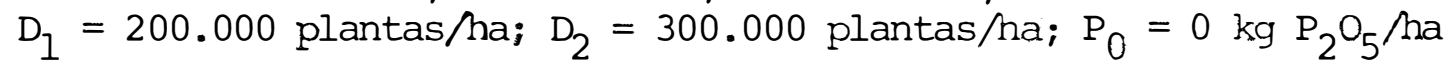

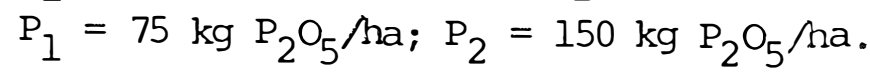




\subsection{Primeira contagem de germinação}

A análise da variância dos dados obtidos para avaliação do vigor das sementes através da primeira contagem de germinação está contida na Tabela 16. Observa-se que o valor de $F$ obtido para cultivares foi significativo indicando que as sementes das cultivares apresentaram diferentes por centagens de germinação na primeira contagem.

O valor de F para doses de fósforo, significativo, indica que as doses de fósforo afetaram o vigor das sementes obtidas avaliado através da primeira contagem de germi nação.

Tabela 16 - Indice de vigor: primeira contagem do teste de genminação. Análise da variância dos dados obtidos (dados transformados pa ra arc sen $\sqrt{\frac{0}{0} / 100}$ ).

\begin{tabular}{|c|c|c|c|c|}
\hline Causas de variação & G.L. & SQ & $g \mathrm{M}$ & $F$ \\
\hline Blocos & 3 & 42,77490 & 14,25830 & $1,01 \mathrm{~ns}$ \\
\hline Cultivares (Cv.) & 3 & 1662,81738 & 534,27246 & $39,30 \star \star$ \\
\hline Doses de Fósforó (P) & 2 & 92,90820 & 46,45410 & $3,29 *$ \\
\hline Densidades (D) & 1 & 3,72216 & 3,72216 & $0,26 \mathrm{~ns}$ \\
\hline Interação Cv.xP & 6 & 35,99780 & 5,99963 & $0,42 \mathrm{~ns}$ \\
\hline Interação Cv.xD & 3 & 8,15234 & 2,71744 & $0,19 \mathrm{~ns}$ \\
\hline Interação PyD & 2 & 14,18212 & 7,09106 & $0,50 \mathrm{~ns}$ \\
\hline Interação CV.XPXD & 6 & 179,22412 & 29,87068 & $2,11 \mathrm{~ns}$ \\
\hline Resỉduo & 69 & 973,09643 & 14,10284 & \\
\hline TOTAL & 95 & 3012,87549 & & \\
\hline
\end{tabular}

C.V. $\%=4,97$

* = significativo a $5 \%$

$* *$ = significativo a $1 \%$ 
Na Tabela 17 estão contidas as médias obtidas para o indice de vigor avaliado através da primeira contagem de germinação. Para as cultivares Carioca e Goiano Precoce não se observaram diferenças no vigor das sementes devido às doses de adubação.

Tabela 17 - Indice de vigor. Primeira contagem de germinação. Médias obti das para doses de fósforo em relação a cultivares e densida des (dados transformados para arc sen $\sqrt{87100^{-}}$). Ilha Solteira, 1981 .

\begin{tabular}{lcccc}
\hline & \multicolumn{3}{c}{ Doses de fósforo } & \\
\cline { 2 - 4 } Cultivares & $\mathrm{P}_{0}$ & $\mathrm{P}_{1}$ & $\mathrm{P}_{2}$ & \\
\hline Goiano Precoce & 69,16 & 70,04 & 70,52 & \\
Bolinha & 71,95 & 72,01 & 75,66 & $\mathrm{P}=2,25$ \\
Carioca & 77,28 & 78,72 & 78,98 & \\
Rico 23 & 79,76 & 79,48 & 82,19 & \\
\hline Densidades & $\mathrm{P}_{0}$ & $\mathrm{P}_{1}$ & $\mathrm{P}_{2}$ & \\
\hline \multicolumn{1}{c}{$\mathrm{D}_{1}$} & 73,83 & 75,27 & 76,75 & $\mathrm{P}=2,25$ \\
$\mathrm{D}_{2}$ & 75,25 & 74,85 & 76,93 & \\
\hline
\end{tabular}

Para as cultivares Bólinha e Rico 23 observou-se um comportamento significativamente superior das sementes de plantas cultivadas com a dose de $150 \mathrm{~kg} / \mathrm{ha}$ de $\mathrm{P}_{2} \mathrm{O}_{5}$ em rela ção às cultivadas com $0 \mathrm{~kg}$ e $75 \mathrm{~kg} / \mathrm{ha}$ de $\mathrm{P}_{2} \mathrm{O}_{5}$.

As plantas cultivadas na densidade de 200.000 
plantas/ha com a dose de $150 \mathrm{~kg} / \mathrm{ha}$ produziram sementes com porcentagem de germinação na primeira contagem significativamente superior às produzidas pelas plantas cultivadas com a dose de $0 \mathrm{~kg} / \mathrm{ha}$ de $\mathrm{P}_{2} \mathrm{O}_{5}$.

Na Tabela 18 estão contidas as médias obtidas para indice de vigor avaliado através da primeira contagem de germinação para os diversos tratamentos. Observa-se que dentro de uma mesma cultivar não ocorreram diferenças significativas no vigor das sementes, sendo que as diferenças foram ve rificadas apenas entre sementes das diferentes cultivares. 
72.

Tabela 18 - Indice de vigor. Primeira contagem de germinação. Médias obti das para as quatro cultivares, doses de fósforo e densidades (dados transformados para arc sen $\sqrt{\frac{0}{2} / 100}$ ). Ilha Solteira, 1981.

\begin{tabular}{|c|c|c|c|c|c|}
\hline \multirow{2}{*}{ Tratamentos } & \multicolumn{4}{|c|}{ Blocos } & \multirow{2}{*}{ Média* } \\
\hline & $A$ & B & $\mathrm{C}$ & $\mathrm{D}$ & \\
\hline $\mathrm{GPD}_{1} \mathrm{P}_{0}$ & 69,73 & 69,73 & 71,57 & 66,42 & 69,36 \\
\hline $\mathrm{GPD}_{2} \mathrm{P}_{0}$ & 64,90 & 69,73 & 69,73 & 71,57 & 68,98 \\
\hline $\mathrm{GPD}_{1} \mathrm{P}_{1}$ & 69,73 & 71,57 & 69,73 & 71,57 & $70,65 \quad b c$ \\
\hline $\mathrm{GPD}_{2} \mathrm{P}_{1}$ & 69,73 & 73,57 & 68,03 & 66,42 & $69,43 \quad c$ \\
\hline $\mathrm{GPD}_{1} \mathrm{P}_{2}$ & 69,73 & 71,57 & 69,73 & 71,57 & $70,65 \mathrm{bc}$ \\
\hline $\mathrm{GPD}_{2} \mathrm{P}_{2}$ & 68,03 & 73,57 & 66,42 & 73,57 & $70,39 \quad c$ \\
\hline $\mathrm{B} \mathrm{D}_{1} \mathrm{P}_{0}$ & 75,82 & 59,73 & 73,57 & 71,57 & $72,67 a b c$ \\
\hline $\mathrm{B} \mathrm{D}_{2} \mathrm{P}_{0}$ & 69,73 & 75,82 & 73,57 & 75,82 & $73,73 \mathrm{abc}$ \\
\hline $\mathrm{B} \mathrm{D}_{1} \mathrm{P}_{1}$ & 73,57 & 73,57 & 73,57 & 73,57 & $73,57 \mathrm{abc}$ \\
\hline $\mathrm{B} \mathrm{D}_{2} \mathrm{P}_{1}$ & 68,03 & 71,57 & 66,42 & 75,82 & $70,46 \mathrm{abc}$ \\
\hline $\mathrm{B} \mathrm{D}_{1} \mathrm{P}_{2}$ & 71,57 & 78,46 & 73,57 & 75,82 & $74,85 a b c$ \\
\hline $\mathrm{B} \mathrm{D}_{2} \mathrm{P}_{2}$ & 75,82 & 78,46 & 75,82 & 75,82 & $76,48 \mathrm{abc}$ \\
\hline $\mathrm{CD}_{1} \mathrm{P}_{0}$ & 81,87 & 78,46 & 78,46 & 75,82 & $78,65 a b c$ \\
\hline C $\mathrm{D}_{2} \mathrm{P}_{0}$ & 73,57 & 75,82 & 75,82 & 78,46 & $75,91 \mathrm{abc}$ \\
\hline $\mathrm{CD}_{1} \mathrm{P}_{1}$ & 73,57 & 75,82 & 78,46 & 75,82 & $75,91 \mathrm{abc}$ \\
\hline $\mathrm{C} \mathrm{D}_{2} \mathrm{P}_{1}$ & 78,46 & 90,00 & 75,82 & 81,87 & 81,53 a \\
\hline $\mathrm{C} \mathrm{D}_{1} \mathrm{P}_{2}$ & 78,46 & 78,46 & 78,46 & 81,87 & $79,31 \mathrm{abc}$ \\
\hline $\mathrm{C} \mathrm{D}_{2} \mathrm{P}_{2}$ & 78,46 & 78,46 & 75,82 & 81,87 & $78,65 \mathrm{abc}$ \\
\hline $\mathrm{R} \mathrm{D}_{1} \mathrm{P}_{0}$ & 78,46 & 78,46 & 75,82 & 75,82 & $77,14 \mathrm{abc}$ \\
\hline $\mathrm{R} \mathrm{D}_{2} \mathrm{P}_{0}$ & 75,82 & 81,87 & 81,87 & 90,00 & $82,39 a$ \\
\hline $\mathrm{R}_{1} \mathrm{P}_{1}$ & 90,00 & 78,46 & 81,87 & 73,57 & $80,97 \mathrm{ab}$ \\
\hline $\mathrm{R} \mathrm{D}_{2} \mathrm{P}_{1}$ & 78,46 & 75,82 & 75,82 & 81,87 & $77,99 \mathrm{abc}$ \\
\hline $\mathrm{R} \mathrm{D}_{1} \mathrm{P}_{2}$ & 78,46 & 78,46 & 90,00 & 81,87 & $82,19 a$ \\
\hline $\mathrm{R} \mathrm{D}_{2} \mathrm{P}_{2}$ & 78,46 & 90,00 & 81,87 & 78,46 & 82,19 a \\
\hline
\end{tabular}

* Médias seguidas de mesma letra não diferem significativamente entre si pelo teste de Tukey a 5\%.

$$
\begin{aligned}
& \text { GP - Goiano Precoce; B - Bolinha; C - Carioca; R - Rico } 23 \\
& \mathrm{D}_{1}=200.000 \mathrm{plantas} / \mathrm{ha} ; \mathrm{D}_{2}=300.000 \text { plantas } / \mathrm{ha} \\
& \mathrm{P}_{0}=0 \mathrm{~kg} \mathrm{P}_{2} \mathrm{O}_{5} \text { / ha; } \mathrm{P}_{1}=75 \mathrm{~kg} \mathrm{P}_{2} \mathrm{O}_{5} / \mathrm{ha} ; \mathrm{P}_{2}=150 \mathrm{~kg} \mathrm{P}_{2} \mathrm{O}_{5} / \mathrm{ha}
\end{aligned}
$$




\subsection{ENVELHECIMENTO RÁPIDO}

A análise da variância dos dados obtidos para avaliação do vigor das sementes através do método do envelhecimento rápido está contida na Tabela 19. Pode-se observar que apenas o valor de $F$ para cultivares foi significativo indican do que as sementes das cultivares apresentaram comportamento diferente em relação ao vigor avaliado através do envelheci mento rápido.

Na Tabela 20 estão contidas as médias obtidas na avaliação dos dados referentes ao índice de vigor através do método do envelhecimento rápido, das sementes das diversas cultivares em diferentes doses de fósforo e densidades. Observa-se que ocorreram diferenças no vigor apenas entre as sementes das quatro cultivares, sendo que dentro de uma mes ma cultivar não se verificou efeitos no vigor das sementes a valiadas através do envelhecimento rápido. Estes resultados evidenciam a influência de componentes varietais no vigor das sementes.

Observou-se um porcentual de germinação das se mentes das cultivares Goiano Precoce e Bolinha superior ao observado no teste de germinação, dando-se a entender que as condições drásticas do teste poderiam haver ocasionado um avigoramento nas sementes destas cultivares. 
Tabela 19 - Indice de vigor: envelhecimento rápido. Análise da variância

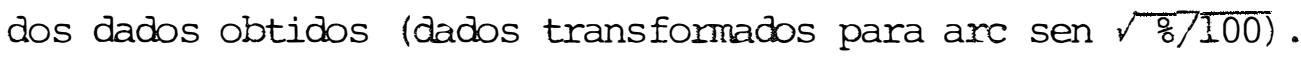

\begin{tabular}{|c|c|c|c|c|}
\hline Causas de variação & G.I. & $S Q$ & aM & $F$ \\
\hline Blocos & 3 & 43,74047 & 14,58015 & $0,60 \mathrm{~ns}$ \\
\hline Cultivares (CV.) & 3 & 379,71923 & 126,57307 & $5,21 * \star$ \\
\hline Doses de Fösforo (P) & 2 & 4,95556 & 2,47778 & $0,10 \mathrm{~ns}$ \\
\hline Densidades (D) & 1 & 45,91088 & 45,91088 & $1,89 \mathrm{~ns}$ \\
\hline Interação CV.xP & $\begin{array}{l}1 \\
6\end{array}$ & 217,71289 & 36,28548 & $1,49 \mathrm{~ns}$ \\
\hline Interação CV.xD & 3 & 179,13940 & 59.71313 & $2,46 \mathrm{~ns}$ \\
\hline Interação PxD & 2 & 12,57958 & 6,28979 & $0,25 \mathrm{~ns}$ \\
\hline Interação Cv.xPxD & 6 & 60,42211 & 10,07035 & $0,41 \mathrm{~ns}$ \\
\hline REsiduo & 69 & 1673,31323 & 24,25091 & \\
\hline TOTAL & 95 & 2617,49341 & & \\
\hline
\end{tabular}

C.V. $\frac{\circ}{\circ}=5,87$

ns = não significativo

$\star *$ = significativo a $1 \%$ 
Tabela 20 - Indice de vigor. Fnvelhecimento räpido. Médias obtidas para as quatro cultivares, doses de fósforo e densidades (dados transformados em arc sen $\sqrt{\frac{0}{0} / 100}$ ). Ilha Solteira, 1981 .

\begin{tabular}{|c|c|c|c|c|c|}
\hline \multirow{2}{*}{ Tratamentos } & \multicolumn{4}{|c|}{ Blocos } & \multirow{2}{*}{ Média* } \\
\hline & $A$ & $\mathrm{~B}$ & $\mathrm{C}$ & $\mathrm{D}$ & \\
\hline $\mathrm{GPD}_{1} \mathrm{P}_{0}$ & 90,00 & 90,00 & 81,87 & 78,46 & $\cdot 85,08$ \\
\hline $\mathrm{GPD}_{2} \mathrm{P}_{0}$ & 78,46 & 90,00 & 90,00 & 81,87 & 85,08 \\
\hline $\mathrm{GPD}_{1} \mathrm{P}_{1}$ & 75,82 & 75,82 & 81,87 & 81,87 & 78,84 \\
\hline $\mathrm{GPD}_{2} \mathrm{P}_{1}$ & 90,00 & 75,82 & 75,82 & 81,87 & 80,87 \\
\hline $\mathrm{GPD}_{1} \mathrm{P}_{2}$ & 78,46 & 81,87 & 78,46 & 90,00 & 82,19 \\
\hline $\mathrm{GPD}_{2} \mathrm{P}_{2}$ & 81,87 & 78,46 & 81,87 & 90,00 & 83,05 \\
\hline $\mathrm{B} \mathrm{D}_{1} \mathrm{P}_{0}$ & 81,87 & 90,00 & 78,46 & 78,46 & 82,19 \\
\hline $\mathrm{B} \mathrm{D}_{2} \mathrm{P}_{0}$ & 78,46 & 75,82 & 81,87 & 78,46 & 78,64 \\
\hline $\mathrm{B} \mathrm{D}_{1} \mathrm{P}_{1}$ & 90,00 & 90,00 & 81,87 & 78,46 & 85,08 \\
\hline $\mathrm{B} \mathrm{D}_{2} \mathrm{P}_{1}$ & 78,46 & 78,46 & 78,46 & 78,46 & 78,46 \\
\hline $\mathrm{B} \mathrm{D}_{1} \mathrm{P}_{2}$ & 90,00 & 90,00 & 81,87 & 78,46 & 85,08 \\
\hline $\mathrm{B} \mathrm{D}_{2} \mathrm{P}_{2}$ & 81,87 & 78,46 & 75,82 & 75,82 & 77,99 \\
\hline$C D_{1} P_{0}$ & 90,00 & 81,87 & 78,46 & 90,00 & 85,08 \\
\hline $\mathrm{C}_{2} \mathrm{P}_{0}$ & 90,00 & 78,46 & 81,87 & 78,46 & 82,19 \\
\hline $\mathrm{C} \mathrm{D}_{1} \mathrm{P}_{1}$ & 90,00 & 81,87 & 90,00 & 90,00 & 87,96 \\
\hline $\mathrm{C} \mathrm{D}_{2} \mathrm{P}_{1}$ & 81,87 & 90,00 & 81,87 & 90,00 & 85,93 \\
\hline$C \mathrm{D}_{1} \mathrm{P}_{2}$ & 90,00 & 90,00 & 90,00 & 81,87 & 87,96 \\
\hline$C D_{2} P_{2}$ & 90,00 & 90,00 & 81,87 & 90,00 & 87,96 \\
\hline $\mathrm{R} \mathrm{D}_{1} \mathrm{P}_{0}$ & 81,87 & 81,87 & 90,00 & 81,87 & 83,90 \\
\hline $\mathrm{R} \mathrm{D}_{2} \mathrm{P}_{0}$ & 81,87 & 90,00 & 81,87 & 90,00 & 85,93 \\
\hline $\mathrm{R} \mathrm{D}_{1} \mathrm{P}_{1}$ & 90,00 & 90,00 & 90,00 & 81,87 & 87,96 \\
\hline $\mathrm{R} \mathrm{D}_{2} \mathrm{P}_{1}$ & 90,00 & 81,87 & 90,00 & 78,46 & 85,08 \\
\hline $\mathrm{R} \mathrm{D}_{1} \mathrm{P}_{2}$ & 81,87 & 81,87 & 75,82 & 90,00 & 82,39 \\
\hline $\mathrm{R} \mathrm{D}_{2} \mathrm{P}_{2}$ & 81,87 & 81,87 & 90,00 & 90,00 & 85,93 \\
\hline
\end{tabular}

GP - Goiano Precoce; B - Bolinha; C - Carioca; R - Rico 23.

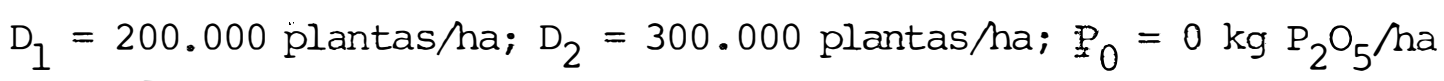
$\mathrm{P}_{1}=75 \mathrm{~kg} \mathrm{P} \mathrm{P}_{5} / \mathrm{ha} ; \mathrm{P}_{2}=150 \mathrm{~kg} \mathrm{P}_{2} \mathrm{O}_{5} / \mathrm{ha}$. 


\subsection{VELOCIDADE DE GERMINAÇÃO}

A análise da variância dos dados obtidos para avaliação do vigor das sementes através do método da velocida de de germinação acha-se contida na Tabela 21 . O valor de $F$ significativo para blocos indica que os tratamentos comportaram-se diferentemente dentro de cada bloco. O valor de $\mathrm{F}$ para cultivares, significativo, revela que as sementes das cultiva res apresentaram velocidades de germinação diferentes. o valor de F significativo. para doses de fósforo indica que as doses de fósforo influíram na velocidade de germinação das sementes obtidas.

Tabela 21 - Indice de vigor: velocidade de germinação. Análise da variân cia dos dados obtidos.

\begin{tabular}{|c|c|c|c|c|}
\hline Causas de variação & G.L. & SQ & QM & $F$ \\
\hline Blocos & 3 & 0,41181 & 0,13727 & $3,42 \star$ \\
\hline Cultivares $(\mathrm{Cv})$. & 3 & 12,29985 & 4,09995 & $102,21 * \star$ \\
\hline Doses de Fósforo (P) & 2 & 0,67437 & 0,33718 & $8,40 * \star$ \\
\hline Densidades (D) & 1 & 0,00769 & 0,00769 & $0,19 \mathrm{~ns}$ \\
\hline Interação Cv.xP & $\frac{1}{6}$ & 0,12374 & 0,02062 & $0,51 \mathrm{~ns}$ \\
\hline Interação CV.xD & 3 & 0,09294 & 0,03098 & $0,77 \mathrm{~ns}$ \\
\hline Interação PxD & 2 & 0,00037 & 0,00018 & $0,00 \mathrm{~ns}$ \\
\hline Interação $\mathrm{Cv} \cdot \mathrm{xPxD}$ & 6 & 0,36668 & 0,06111 & $1,52 \mathrm{~ns}$ \\
\hline Resíduo & 69 & 2,76758 & 0,04010 & \\
\hline TOTAL & 95 & 16,74507 & & \\
\hline
\end{tabular}

C.V. $\frac{\circ}{\circ}=1,68$

ns $=$ não significativo

* = significativo a $5 \%$

$\star \star=$ significativo a $1 \%$ 
Na Tabela 22 estão contidas as médias obtidas para velocidade de germinação das sementes das cultivares com relação aos efeitos das doses de fósforo.

Para a cultivar Rico 23 não verificou diferença significativa entre os vigores das sementes obtidas, avalia do através da velocidade de germinação. Já para as cultivares Goiano Precoce, Bolinha e Carioca observou-se um maior vigor das sementes obtidas de plantas cultivadas com a dose de 150 $\mathrm{kg} / \mathrm{ha}$ de $\mathrm{P}_{2} \mathrm{O}_{5}$ em relação às sementes de plantas cultivadas com as doses de $0 \mathrm{~kg}$ e $75 \mathrm{~kg} / \mathrm{ha}$ de $\mathrm{P}_{2} \mathrm{O}_{5}$.

Já com relação às densidades, observa-se um comportamento superior das sementes de plantas cultivadas com $150 \mathrm{~kg}$ de $\mathrm{P}_{2} \mathrm{O}_{5} /$ ha em relação às sementes de plantas cultivadas com as outras duas doses em ambas densidades.

Na Tabela 23 estão contidas as médias obtidas para velocidade de germinação das sementes nos diversos tratą mentos. Observa-se principalmente as diferenças ocorridas devido às diferenças varietais, e que não se verificaram dife renças significativas na velocidade de germinação das sementes de uma mesma cultivar. 
Tabela 22 - Indice de vigor: velocidade de germinação. Médias obtidas para doses de fósforo en relação a cultivares e densidades. Itha Solteira, 1981.

\begin{tabular}{lcccc}
\hline & \multicolumn{3}{c}{ Doses de fósforo } & DMS TUKEY 5\% \\
\cline { 2 - 3 } & $\mathrm{P}_{0}$ & $\mathrm{P}_{1}$ & $\mathrm{P}_{2}$ & \\
\hline Goiano Precoce & 11,30 & 11,28 & 11,44 & $\mathrm{P}=0,12$ \\
Bolinha & 11,60 & 11,59 & 11,89 & \\
Carioca & 12,02 & 12,06 & 12,19 & \\
Rico 23 & 12,21 & 12,25 & 12,33 & \\
\hline Densidades & $\mathrm{P}_{0}$ & $\mathrm{P}_{1}$ & $\mathrm{P}$ & \\
\hline \multicolumn{1}{c}{$\mathrm{D}_{1}$} & 11,77 & 11,78 & 11,96 & \\
$\mathrm{D}_{2}$ & 11,79 & 11,80 & 11,97 & \\
\hline
\end{tabular}


Tabela 23 - Indice vigor (velocidade de germinação) de sementes de 4 cultivares de feijão cultivadas em três níveis de adubação fosfa tada e duas densidades de plantas. Ilha Solteira, 1982.

\begin{tabular}{|c|c|c|c|c|c|c|}
\hline \multirow{2}{*}{ Tratamentos } & \multicolumn{4}{|c|}{ Blocos } & \multicolumn{2}{|c|}{ Média* } \\
\hline & A & B & $C$ & $\mathrm{D}$ & & \\
\hline $\mathrm{GPD}_{1} \mathrm{P}_{0}$ & 11,33 & 11,33 & 11,58 & 11,00 & 11,31 & g \\
\hline $\mathrm{GPD}_{2} \mathrm{P}_{0}$ & 10,92 & 11,33 & 11,50 & 11,42 & 11,29 & g \\
\hline $\mathrm{GPD}_{1} \mathrm{P}_{1}$ & 11,17 & 11,42 & 11,17 & 11,42 & 11,29 & g \\
\hline $\mathrm{GPD}_{2} \mathrm{P}_{1}$ & 11,50 & 11,67 & 10,92 & 11,00 & 11,27 & g \\
\hline $\mathrm{GPD}_{1} \mathrm{P}_{2}$ & 11,50 & 11,42 & 11,50 & 11,58 & 11,50 & efg \\
\hline $\mathrm{GPD}_{2} \mathrm{P}_{2}$ & 11,08 & 11,67 & 11,17 & 11,67 & 11,39 & $\mathrm{fg}$ \\
\hline $\mathrm{B} \mathrm{D}_{1} \mathrm{P}_{0}$ & 11,75 & 11,33 & 11,67 & 11,58 & 11,58 & defg \\
\hline $\mathrm{B} \mathrm{D}_{2} \mathrm{P}_{0}$ & 11,33 & 11,92 & 11,50 & 11,75 & 11,62 & cdefg \\
\hline $\mathrm{B} \mathrm{D}_{1} \mathrm{P}_{1}$ & 11,67 & 11,83 & 11,50 & 11,67 & 11,66 & bcdefg \\
\hline $\mathrm{B} \mathrm{D}_{2} \mathrm{P}_{1}$ & 11,25 & 11,58 & 11,33 & 11,92 & 11,52 & efg \\
\hline $\mathrm{B} \mathrm{D}_{1} \mathrm{P}_{2}$ & 11,58 & 12,33 & 11,58 & 11,75 & 11,81 & abcdefg \\
\hline $\mathrm{B} \mathrm{D}_{2} \mathrm{P}_{2}$ & 11,92 & 12,17 & 11,92 & 11,92 & 11,98 & abcdef \\
\hline$C D_{1} P_{0}$ & 12,25 & 12,00 & 12,00 & 11,92 & 12,04 & abcde \\
\hline $\mathrm{CD}_{2} \mathrm{P}_{0}$ & 11,67 & 12,08 & 12,08 & 12,17 & 12,00 & abcdef \\
\hline $\mathrm{CD}_{1} \mathrm{P}_{1}$ & 11,67 & 11,92 & 12,00 & 11,92 & 11,87 & abcdefg \\
\hline $\mathrm{C} \mathrm{D}_{2} \mathrm{P}_{1}$ & 12,17 & 12,50 & 12,08 & 12,25 & 12,25 & $a b c$ \\
\hline$C D_{1} P_{2}$ & 12,00 & 12,33 & 12,17 & 12,25 & 12,18 & abcd \\
\hline $\mathrm{C} \mathrm{D}_{2} \mathrm{P}_{2}$ & 12,33 & 12,17 & 12,08 & 12,25 & 12,20 & $a b c$ \\
\hline $\mathrm{R} \mathrm{D}_{1} \mathrm{P}_{0}$ & 12,17 & 12,33 & 12,08 & 12,08 & 12,16 & abcd \\
\hline $\mathrm{R} \mathrm{D}_{2} \mathrm{P}_{0}$ & 12,08 & 12,25 & 12,25 & 12,50 & 12,27 & $a b$ \\
\hline $\mathrm{R} \mathrm{D}_{1} \mathrm{P}_{1}$ & 12,50 & 12,33 & 12,42 & 12,00 & 12,31 & \\
\hline $\mathrm{R} \mathrm{D}_{2} \mathrm{P}_{1}$ & 12,17 & 12,08 & 12,08 & 12,42 & 12,18 & abcd \\
\hline $\mathrm{R} \mathrm{D}_{1} \mathrm{P}_{2}$ & 12,33 & 12,17 & 12,50 & 12,42 & 12,35 & \\
\hline $\mathrm{R} \mathrm{D}_{2} \mathrm{P}_{2}$ & 12,17 & 12,50 & 12,42 & 12,17 & 12,31 & \\
\hline
\end{tabular}

* Médias seguidas de mesma letra não diferem significativamente entre si pelo teste de Tukey a $1 \%$

GP - Goiano Precoce; B - Bolinha; C - Carioca; R - Rico 23.

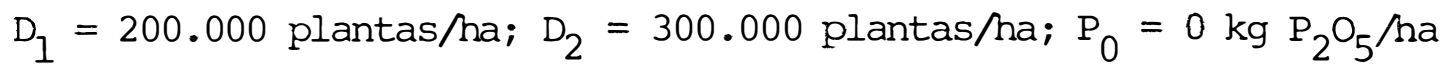
$\mathrm{P}_{1}=75 \mathrm{~kg} \mathrm{P} \mathrm{O}_{5} / \mathrm{ha} ; \mathrm{P}_{2}=150 \mathrm{~kg} \mathrm{P} \mathrm{O}_{5} / \mathrm{ha}$ 


\subsection{TeOr de proteína nas SEMEntes}

A análise da variância dos dados obtidos para teor de proteína nas sementes está contida na Tabela 24.

O valor de F altamente significativo para cultivares indica que os teores de proteina nas sementes foram diferentes entre as cultivares. Os valores de F obtidos para doses de fósforo, para as interações CV.xP e PxD,significati vos, indicam que as doses de fósforo influíram no teor de prô teina das sementes.

Os valores de $F$ obtidos para densidades e para as interações Cv.xD, PxD e Cv.xPxD indicam que o teor de proteína nas sementes obtidas variou segundo as densidades, cultivares e densidades, doses de fósforo e densidades e segundo cultivares, doses de fósforo e densidades. Em vista destes resultados foi feita a anālise detalhada das interações verificadas, estando a mesma contida na Tabela 24 .

Com relação ao detalhamento para doses de fósforo, observa-se pelos valores de F obtidos, significativos, que o teor de proteína das sementes das quatro cultivares variam tanto com a dose de $0 \mathrm{~kg}$, como com a dose de $75 \mathrm{~kg}$ ou cam a dose de $150 \mathrm{~kg} / \mathrm{ha}$ de $\mathrm{P}_{2} \mathrm{O}_{5} \cdot$

Os valores de $F$ obtidos para $P$ dentro das cultivares, significativos, indicam que dentro de uma mesma cul- 
Tabela 24 - Teor de proteína nas sementes. Análise da variância dos dados obtidos (dados transformados para arc sen $\sqrt{\frac{8}{8} / 100}$ ).

\begin{tabular}{|c|c|c|c|c|}
\hline Causas de variação & G.L. & $S Q$ & $Q M$ & $F$ \\
\hline $\begin{array}{l}\text { Blocos } \\
\text { Cultivares (Cv.) } \\
\text { Doses de Fósforo (P) } \\
\text { Densidades (D) } \\
\text { Interação Cv.xP } \\
\text { Interação Cv.xD } \\
\text { Interação PxD } \\
\text { Interação CV.XPxD } \\
\quad \text { Resĩuoo }\end{array}$ & $\begin{array}{r}3 \\
3 \\
2 \\
1 \\
6 \\
3 \\
2 \\
6 \\
69\end{array}$ & $\begin{array}{r}0,16378 \\
184,96679 \\
2,28646 \\
0,59088 \\
0,58947 \\
0,55175 \\
0,61441 \\
1,14739 \\
2,142761\end{array}$ & $\begin{array}{r}0,05459 \\
61,65559 \\
1,14323 \\
0,59088 \\
0,09824 \\
0,18391 \\
0,30720 \\
0,19123 \\
0,03105\end{array}$ & $\begin{array}{r}1,75 \mathrm{~ns} \\
1985,39 \star \star \\
36,81 \star \star \\
19,02 \star \star \\
3,16 \star \star \\
5,92 \star \star \\
9,89 \star \star \\
6,15 \star \star\end{array}$ \\
\hline
\end{tabular}

$\begin{array}{llllc}\text { Doses de Fósforo' } & 1 & 2,07378 & 2,07378 & 66,77 \star \star \\ \text { Doses de Fósforo" } & 1 & 0,21262 & 0,21262 & 6,84 *\end{array}$

$P$ dentro de Goiano Precoce $\quad 2 \quad 0,52522 \quad 0,26261 \quad 8,45 *$ *

$P$ dentro de Bolinha

$P$ dentro de Carioca

$P$ dentro de Rico 23

$2 \quad 1,30739 \quad 0,65369 \quad 21,05 * \star$

$2 \quad 0,52216 \quad 0,26108 \quad 8,40 * \star$

$2 \quad 0,52114 \quad 0,26057 \quad 8,39 * *$

Cultivares dentro de $P_{0} \quad \begin{array}{lllll}3 & 65,36519 & 21,78839 & 701,61 * *\end{array}$

Cultivares dentro de $P_{1} \quad 3 \quad 62,47061 \quad 20,82353 \quad 670,54$ **

Cultivares dentro de $\mathrm{P}_{2} \quad 3 \quad 57,72045$ 19,24015 619,56**
D. dentro de Goiano Precoce
D. dentro de Bolinha
D. dentro de Carioca
D. dentro de Rico 23
$1 \quad 0,28407$
0,01351
$0,43 \mathrm{~ns}$
$1 \quad 0,00094$
0,28407
9,14 **
$1 \quad 0,84410$
0,0094
0,84410
$0,03 \mathrm{~ns}$
$27,18 * \star$

\begin{tabular}{lcccc} 
Cultivares dentro de $\mathrm{D}_{1}$ & 3 & 89,35346 & 29,78448 & $959,10^{\star \star}$ \\
Cultivares dentro de $\mathrm{D}_{2}$ & 3 & 96,16508 & 32,05502 & $1032,21^{\star \star}$ \\
\hline Densidades dentro de $\mathrm{P}_{0}$ & 1 & 0,03388 & 0,03388 & $1,09 \mathrm{~ns}$ \\
Densidades dentro de $\mathrm{P}_{1}$ & 1 & 0,42242 & 0,42242 & $13,60^{\star \star}$ \\
Densidades dentro de $\mathrm{P}_{2}$ & 1 & 0,74897 & 0,74897 & $24,11^{\star \star}$ \\
P dentro de $\mathrm{D}_{1}$ & 2 & 2,6345 & 1,31772 & $42,43^{\star \star}$ \\
P dentro de $\mathrm{D}_{2}$ & 2 & 0,26539 & 0,13269 & $4,27^{\star}$
\end{tabular}

\footnotetext{
C.V. $\left(\frac{\circ}{6}\right)=0,58$

ns = não significativo

* = significativo à 5\%

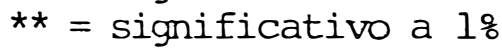


tivar, o teor de proteína na semente obtida variou com a dose de fósforo. Por outro lado, os valores de $F$ obtidos para cultivares dentro de doses de fósforo, significativos, indicam que dentro de um mesma dose de fósforo as sementes apresentaram teores de proteína diferentes em função da cultivar. Os valores de $\mathrm{F}$ obtidos para densidades dentro de Goiano Precoce e densidades dentro de Rico 23, significativos, indicam que nestas cultivares as densidades de plantas influíram no teor de proteína das sementes. Por outro lado, os valores ob tidos para cultivares dentro de $\mathrm{D}_{1}$ e cultivares dentro de $\mathrm{D}_{2}$ ' significativos, indicam que as sementes das plantas das diferen tes cultivares apresentaram teores de proteína diferentes den tro das referidas densidades.

Os valores de $F$ obtidos para densidades dentro de $\mathrm{P}_{1}$ e densidades dentro de $\mathrm{P}_{2}$, significativos, indicam que nestas doses de fósforo as densidades afetaram o teor de pro teina das sementes das plantas neles cultivadas.

Os valores de $\mathrm{F}$, significativos, para $\mathrm{P}$ dentro de $\mathrm{D}_{1}$ e $\mathrm{P}$ dentro de $\mathrm{D}_{2}$ indicam que em ambas as densidades as doses de fósforo afetaram o teor de proteina das sementes.

Na Tabela 25 estão contidas as médias obtidas para teor de proteína nas sementes para diferentes cultivares, níveis de fósforo e densidades. Com relação às cultivares, ob serva-se que as sementes da cultivar Goiano Precoce apresenta ram teor de proteína significativamente superior aos das de mais, vindo a seguir Rico 23, Carioca e Bolinha, sendo que to 
Tabela 25 - Teor de proteína nas sementes. Médias obtidas para diferentes cultivares, doses, de fósforo e densidades (dados transformados para arc sen $\sqrt{\frac{9}{8} / \overline{100}}$ ). Ilha Solteira, 1981.

\begin{tabular}{|c|c|c|c|c|}
\hline Cultivares x Doses de Fösforo & $\mathrm{P}_{0}$ & $P_{1}$ & $\mathrm{P}_{2}$ & DMS Tukey 58 \\
\hline Goiano Preosoe & 31,99 & 32,32 & 32,30 & Cv.den. $P=0,23$ \\
\hline Bolinha & 27,97 & 28,37 & 28,52 & $P$ den. $C v .=0,21$ \\
\hline Carioca & 29,93 & 30,28 & 30,18 & \\
\hline Rico 23 & 30,25 & 30,30 & 30,59 & \\
\hline Cultivares x Densidades & $\mathrm{D}_{1}$ & & 2 & \\
\hline Goiano Precoce & 32,23 & 32 & & \\
\hline Bolinha & 28,39 & 28 & & $C v \cdot$ den. $D=0,19$ \\
\hline Carioca & 30,12 & 30 & & D. den.Cv. $=0,13$ \\
\hline Rico 23 & 30,57 & 30 & & \\
\hline Doses de Fósforo x Densidades & $\mathrm{D}_{1}$ & & 2 & \\
\hline $\mathrm{P}_{0}$ & 30,00 & 30 & & P. den. $D=0,15$ \\
\hline $\mathrm{P}_{1}$ & 30,43 & 30 & & $D$ den $. P=0,13$ \\
\hline $\mathrm{P}_{2}$ & 30,55 & 30 & & \\
\hline
\end{tabular}


das diferiram significativamente entre si. Nas cultivares Goia no Precoce, Bolinha e Carioca os teores de proteína nas semen tes das plantas cultivadas com as doses de $75 \mathrm{~kg} / \mathrm{ha}$ e $150 \mathrm{~kg} / \mathrm{ha}$ foram significativamente superiores aos daquelas cultivadas com a dose de $0 \mathrm{~kg} / \mathrm{ha}$ de $\mathrm{P}_{2} \mathrm{O}_{5}$. Porém, na cultivar Rico 23 verificou-se que com a dose de $150 \mathrm{~kg}$ de $\mathrm{P}_{2} \mathrm{O}_{5} / \mathrm{ha}$ as sementes obtidas apresen taram teores significativamente superiores aos das sementes ob tidas de plantas cultivadas com as doses de $75 \mathrm{~kg} / \mathrm{ha}$ e $0 \mathrm{~kg} / \mathrm{ha}$ de $\mathrm{P}_{2} \mathrm{O}_{5}$

Com relação às densidades, verificou-se que as sementes obtidas das cultivares na densidade de 200.000 plan tas apresentaram teores de proteína diferentes, com todas as cultivares diferindo significativamente entre si na seguinte ordem decrescente: Goiano Precoce, Rico 23, Carioca e Bolinha. Já na densidade de 300.000 plantas as sementes das culti vares Carioca e Rico 23 apresentaram teores de proteínas esta tisticamente semelhantes entre si, porēm diferentes dos teores das demais.

$\mathrm{Na}$ densidade de 200.000 plantas/ha observou -se que as sementes das plantas cultivadas com as doses de 75 $\mathrm{kg} / \mathrm{ha}$ e $150 \mathrm{~kg} / \mathrm{ha}$ de $\mathrm{P}_{2} \mathrm{O}_{5}$ apresentaram teores de proteína significativamente diferentes das sementes das plantas cultiva das com $0 \mathrm{~kg} / \mathrm{ha}$ de $\mathrm{P}_{2} \mathrm{O}_{5}$. Já na densidade de 300.000 plantas a penas as sementes das plantas cultivadas com $150 \mathrm{~kg} /$ /ha diferiram significativamente $\cdots$ das cultivadas com $0 \mathrm{~kg} / \mathrm{ha}$. 


\subsection{TEOR DE FÓSFORO NAS SEMENTES}

A análise da variância dos dados obtidos para teor de fósforo nas sementes está contida na Tabela 26.

O valor de $F$ para cultivares, altamente significativo, indica que as sementes das cultivares apresentaram diferentes teores de fósforo. O valor de $F$ para a interação Cv.XP, significativo, indica que dependendo da cultivar a dose de fósforo afetou o teor de fósforo da semente. Em vista disto, foi feito um detalhamento da interação verificada, o qual se encontra contido na Tabela 26. Observa-se que as do "ses de fósforo influíram no teor de fósforo das sementes nas cultivares Goiano Precoce e Bolinha, haja visto que o F para P dentro destas cultivares foi significativo. Por outro lado, observa-se que as sementes produzidas por plantas cultivadas com uma determinada dose de fósforo apresentaram teores de fósforo diferentes dependendo da cultivar.

os valores obtidos para teor de fósforo nas sementes, com as médias obtidas para as diferentes cultivares com relação a fósforo estão contidos na Tabela 27. Observa-se que as sementes da cultivar Goiano Precoce apresen taram teores significativamente superiores aos das demais. As sementes das cultivares Carioca e Rico 23 apresentaram teores de fósforo semelhantes para todas as doses, enquanto que as se mentes da cultivar Bolinha oriundas de plantas cultivadas com as doses de 0 e $75 \mathrm{~kg}$ de $\mathrm{P}_{2} \mathrm{O}_{5} /$ ha apresentaram teores de fósforo 
Tabela 26 - Teor de fósforo nas sementes. Análise da variância dos dados obtidos.

\begin{tabular}{|c|c|c|c|c|}
\hline Causas de variação & G.I. & SQ & $Q M$ & $F$ \\
\hline $\begin{array}{l}\text { Blocos } \\
\text { Cultivares (CV.) } \\
\text { Dóses de Fósforo (P) } \\
\text { Densidades (D) } \\
\text { Interação CV.xP } \\
\text { Interação Cv.xD } \\
\text { Interação PxD } \\
\text { Interação Cv.xPxD } \\
\quad \text { Residuo. }\end{array}$ & $\begin{array}{r}3 \\
3 \\
2 \\
1 \\
6 \\
3 \\
2 \\
6 \\
69\end{array}$ & $\begin{array}{l}0,00013 \\
0,02516 \\
0,00018 \\
0,00001 \\
0,00164 \\
0,00027 \\
0,00000 \\
0,00040 \\
0,00393\end{array}$ & $\begin{array}{l}0,00004 \\
0,00838 \\
0,00009 \\
0,00001 \\
0,00027 \\
0,00009 \\
0,00000 \\
0,00006 \\
0,00005\end{array}$ & $\begin{array}{r}0,76 \mathrm{~ns} \\
147,12 \star \star \\
1,65 \mathrm{~ns} \\
0,29 \mathrm{~ns} \\
4,79 \star \star \\
1,58 \mathrm{~ns} \\
0,04 \mathrm{~ns} \\
1,18 \mathrm{~ns}\end{array}$ \\
\hline TOIAI & 95 & 0,03176 & & \\
\hline $\begin{array}{l}\text { Doses de Fósforo' } \\
\text { Doses de Fösforo" }\end{array}$ & $\begin{array}{l}1 \\
1\end{array}$ & $\begin{array}{l}0,00016 \\
0,00002\end{array}$ & $\begin{array}{l}0,00016 \\
0,00002\end{array}$ & $\begin{array}{l}2,96 \mathrm{~ns} \\
0,35 \mathrm{~ns}\end{array}$ \\
\hline $\begin{array}{l}\text { P dentro de Goiano Precoce } \\
\text { P dentro de Bolinha } \\
\text { P dentro de Carioca } \\
\text { P dentro de Rioo } 23\end{array}$ & $\begin{array}{l}2 \\
2 \\
2 \\
2\end{array}$ & $\begin{array}{l}0,00044 \\
0,00125 \\
0,00001 \\
0,00012\end{array}$ & $\begin{array}{l}0,00022 \\
0,00062 \\
0,00000 \\
0,00006\end{array}$ & $\begin{array}{l}3,86 * \\
11,00 * \star \\
0,12 \text { ns } \\
1,06 \text { ns }\end{array}$ \\
\hline $\begin{array}{l}\text { Cultivares dentro de } \mathrm{P}_{0} \\
\text { Cultivares dentro de } \mathrm{P}_{1} \\
\text { Cultivares dentro de } \mathrm{P}_{2}\end{array}$ & $\begin{array}{l}3 \\
3 \\
3\end{array}$ & $\begin{array}{l}0,00927 \\
0,01175 \\
0,00577\end{array}$ & $\begin{array}{l}0,00309 \\
0,00391 \\
0,00192\end{array}$ & $\begin{array}{l}54,21 * * \\
68,72 * \star \\
33,78 * \star\end{array}$ \\
\hline
\end{tabular}

C.V. $\frac{\circ}{8}=3,15$

ns = não significativo

* = significativo a $5 \%$

$\star *$ = significativo a 10 
Tabela 27 - Teor de fósforo nas sementes. Médias obtidas para diferentes cultivares e doses de fósforo e densidades. Ilha solteira, 1981.

Cultivares x Doses de Fósforo $\quad P_{0} \quad P_{1} \quad P_{2} \quad$ DMS Tukey 58

$\begin{array}{lllll}\text { Goiano Precoce } & 0,26 & 0,27 & 0,26 & \text { Cv.den.P }=0,01 \\ \text { Bolinha } & 0,21 & 0,21 & 0,23 & \text { P den.Cv. }=0,01 \\ \text { Carioca } & 0,23 & 0,23 & 0,23 & \\ \text { Rico 23 } & 0,23 & 0,23 & 0,23 & \end{array}$


significativamente inferiores ao daquelas cultivares, porém não diferindo com a dose de $150 \mathrm{~kg} / \mathrm{ha}$.

Com relação a doses de fósforo, observou-se pa ra a cultivar Bolinha que as sementes de plantas cultivadas com $150 \mathrm{~kg}$ de $\mathrm{P}_{2} \mathrm{O}_{5} / \mathrm{ha}$ apresentaram maiores teores que as sementes de plantas cultivadas com doses de 0 e $75 \mathrm{~kg} / \mathrm{ha}$ de $\mathrm{P}_{2} \mathrm{O}_{5}$.

\subsection{Aspectos gerais}

Analisando os diversos resultados obtidos, verifica-se que de um modo geral, os valores de: altura de plan tas, número de vagens por planta, produção de sementes, peso de mil sementes e teor de proteína aumentaram com a dose de fósforo (Apêndice l).

Apesar de se ter verificado uma diminuição no número de vagens por planta, na maior densidade a produção das cultivares sempre foram maiores dentro de um mesmo nível de fósforo.

Para algumas cultivares observou-se efeitos das doses de fósforo sobre a porcentagem de germinação e vigor das sementes obtidas, porém ficaram evidenciadas as influências varietais no desempenho das sementes haja visto que dependendo da cultivar o comportamento foi diferente. Por outro lado, este efeito do fósforo aumentando o vigor das sementes concor dam com resultados obtidos por BASTOS et alie (1982) que veri ficaram efeitos do fósforo beneficiando o vigor das sementes. 
Dentro dos diversos parâmetros analisados, verificou-se um comportamento diferencial das cultivares, com relação à sua resposta ao fósforo e às densidades.

As sementes das cultivares que apresentaram maio res teores de proteína também apresentaram teores mais elevados de fósforo, sendo que os valores encontrados estão de acordo com os verificados na literatura, entre os quais os valores estipulados por VIEIRA (1978).

Os testes de vigor utilizados: velocidade de germinação e primeira contagem de germinação, apre sentaram valores bastante concordantes e em seus resultados se verificaram as mesmas tendências que se observaram no teste de germinação. Já o teste de envelhecimento rápido parece haver provocado um avigoramento nas sementes das cultivares Goiano Precoce e Bolinha (aumentando a porcentagem de germinação) fa zendo com que os resultados obtidos neste teste fossem discor dantes dos obtidos nos outros. No entanto, para as cultivares Carioca e Rico 23 neste teste se verificaram as mesmas tendên cias nos resultados verificados para velocidade de germinação e primeira contagem. 


\section{CONCLUSÕES}

Após as análises dos dados obtidos, pôde-se con cluir que:

- As cultivares responderam diferentemente à adubação fosfatą da e à densidade de plantas.

- A altura das plantas, número de vagens por planta e produ ção de sementes aumentaram substancialmentercom a dose de fertilização fosfatada.

- Em relação à produção de sementes, para todas as cultivares os melhores resultados foram obtidos com $150 \mathrm{~kg} / \mathrm{ha}$ de $\mathrm{P}_{2} \mathrm{O}_{5} \mathrm{e}$ 300.000 plantas/ha.

- A cultivar Carioca apresentou-se como a mais produtiva. 
- A densidade de plantas afetou a produção de sementes das . cultivares porém não afetou a qualidade das mesmas.

- A fertilização fosfatada afetou o peso de mil sementes das cultivares Goiano Precoce, Carioca e Rico 23 porém não afetou o peso de mil sementes da cultivar Bolinha. 


\section{LITERATURA CITADA}

ABRAHÃO, J.T.M. e F.F. TOLEDO, 1969. Resultados preliminares de testes de vigor em sementes de feijoeiro. Revista de Agricultura, Piracicaba, 44(4): 132, 160-3.

AGUDELO, D.; O.L. HERNANDEZ e R.G. BASTIDAS, 1972. Efecto de la densidad de problación en el rendimento y otras características agronômicas del frijol (Phaseolus vulgaris L.) de crescimiento voluble y arbustivo. Acta agronômica, Palmira, Colômbia, 22: 39-50.

ALMEIDA, D.L.; G.G. PESSANHA e A.F. PENTEADO, 1973. Efeito da calagem e da adubação fosfatada e nitrogenada na nodulação e produção do feijoeiro (Phaseolus vulgaris L.). Pesquisa Agropecuária Brasileira, Sērie Agronomia, Brasília, ㅁ: 127-130 . 
ALMEIDA, L.D'A.; A.S. POMPEU; E.A. BULISANI; P. RONZELLI JONIOR; A.A. VEIGA e J.L. CASTRO, 1982a. Comportamento de cultivares e linhagens de feijoeiro (Phaseolus vulgaris L.) na região sudoeste do Estado de são Paulo. In: Anais da 1ạ Reunião Nacional de Pesquisa de Feijão, Goiânia, p.29-3l.

ALMEIDA, L.D'A.; A.S. POMPEU; E.A. BULISANI; P. RONZELLI JUNIOR e N. BORTOLETO, 1982b. Competição de cultivares e linhagens de feijão na região noroeste do Estado de são Paulo. In: Anais da lạ Reunião Nacional de Pesquisa de Feijão, Goiânia, p. 32-35.

ALMEIDA, L.D'A.; C.T. FEITOSA; E.A. BULISANI; P. RONZELLI JONIOR; N. LEITE e N.C. SCHIMIDT, 1982c. Adubação mineral do feijoeiro no Vale do Paraíba. In: Anais da lạ Reunião Nacional de Pesquisa de Feijão, Goiânia, p.182-184.

ALMEIDA, L.D'A.; E.A. BULISANI; S. ALVES e T.R. ROCHA, 1977. Competição de cultivares de feijoeiro em Mococa e Monte Alegre do Sul. Bragantia, Campinas, 36(10): 125-130.

ALMEIDA, L.D'A.; H.F. LEITÃO e S. MIYASAKA, 1971. Feijoeiro no Estado de são Paulo. Circular do Instituto Agronômico de Campinas, n. 7, 8p.

BASTOS, A.R.; A. JUNQUEIRA NETTO; J.F. SILVEIRA e A.C. FRAGA, 1982. Efeitos de fósforo, molibdênio e cobalto sobre a germinação e vigor das sementes de feijão (Phaseolus vulgaris L.). In: Anais da lạ Reunião Nacional de Pesquisa de Feijão, Goiânia-Go, p.339-340. 
BATISTA, C.M.; N. BRUNE e J.M. BRAGA, 1975. Efeitos da população de plantas e da época de plantio no crescimento do feijoeiro (Phaseolus vulgaris L.). V - Absorção de macronutrientes. Experientiae, Viçosa, 19(3): 33-57.

BENNETT, J.P.; M.W. ADAMS e C. BURGA, 1977. Pod yield component variation and intercorrelation in Phaseolus vulgaris (L.) as affected by planting density. Crop Science, Madison, $\underline{17}(1): 73-75$.

BERGER, P.G.; C. VIEIRA; J.M. CHAGAS e A.A. CARDOSO, 1982. Resposta do feijoeiro (Phaseolus vulgaris L.) à adubação nitrogenada e fosfatada. In: Anais da lạ Reunião Nacional de Pesquisa de Feijão, Goiânia, p.178-181.

BRAGA, J.M., 1969. Comparação entre fosfatos aplicados ao feijoeiro, I - Trabalhos em casa-de-vegetação. Revista Ceres, Viçosa, 16(88): 88-101.

BRASIL. Ministério da Agricultura - Divisão de Sementes e Mudas, 1976. Regras para anālise de sementes. Brasilia, 188p.

BULISANI, E.A.; L.D'A. ALMEIDA e S. ALVES, 1982. Resposta de cinco cultivares de feijão a níveis crescentes de $\mathrm{N}, \mathrm{P}_{2} \mathrm{O}_{5} \mathrm{e}$ $\mathrm{K}_{2} \mathrm{O}$ em condições de campo. In: Anais da lạ Reunião Nacional de Pesquisa de Feijão, Goiânia, p.187-189.

CAIXETA, J.T., 1978. Irrigação do feijoeiro. Informe Agropecuário, Belo Horizonte, 出(46): 36-40. 
CAIXETA, J.T.; R. MARINATO e M.S.F. DANTAS, 1978. Efeitos da aplicação de quatro lâminas de āgua e três níveis de fertilizantes no rendimento do feijoeiro comum (Phaseolus vulgaris L.). I - Projeto Feijāo, relatório 73/75, Belo Horizonte, p. 27-29.

CARVALHO, N.M. e J. NAKAGAWA, 1980. Sementes: Ciência, Tecnologia e Produção. Campinas, Fundação Cargill, 326p.

CENTRO INTERNACIONAL DE AGRICULTURA TROPICAL, 1981. Informe CIAT. Cali, $124 \mathrm{p}$.

COBRA NETO, A.; W.R. ACCORSI e E. MALAVOLTA, 1971. Estudos sobre a nutrição mineral do feijoeiro (Phaseolus vulgaris $\mathrm{L}$. var. Roxinho). Anais da Escola Superior de Agricultura "Iuiz de Queiroz", Piracicaba, 28: 257-274.

COSTA, N.D., 1982. Avaliação regional de cultivares de feijão (Phaseolus vulgaris L.) conduzido sob regime de irrigação. In: Anais da lạ Reunião Nacional de Pesquisa de Feijão, Goiânia, p. 5.

CROTHERS, S.E. E D.T. WESTERMANN, 1976. Plant populationeffects on the seed yield of Phaseolus vulgaris L. Agronomy Journal, Madison, 68: 958-960.

CUNHA, J.M.; M.S.F. DANTAS e L.A. LIMA, 1975. Cultura do feijoeiro no Alto Paranaíba. Patos de Minas, s.ed. $12 \mathrm{p}$.

DELOUCHE, J.C. e C.C. BASKIN, 1973. Accelerated aging techniques for predicting the relative storability of seed lots. Seed Science and Technology, Norway, $\underline{1}(1): 427-452$. 
DEMATTE, J.L.I., 1980. Levantamento detalhado dos solos do "Campus" Experimental de Ilha Solteira. Piracicaba, 114p. (mimeografado)

EIRA, P.A.; G.G. PESSANHA; A.P.P. SOUZA BRITTO e A.R. CARBAJAL, 1973. Comparação de esquemas experimentais em experimentos de adubação mineral de nitrogênio e fósforo na cultura do feijão (Phaseolus vulgaris L.). Pesquisa Agropecuária Brasileira, Série Agronomia, Brasilia, 8: 121-125.

EIRA, P.A.; G.G. PESSANHA; D.P.P. SOUZA BRITTO e A. R. CARBAJAL, 1974. Adubação mineral de fósforo e potássio na cultura do feijão e verificação do efeito residual. Pesquisa Agropecuária Brasileira, Série Agronomia, Brasília, 9 : 121-124 .

EMPRESA BRASILEIRA DE PESQUISA AGROPECUÁRIA, 1978. Nosso feijão tem muitos problemas. Dirigente Rural, são Paulo, $\underline{\mathbf{1 2}}$ $(1 / 2): 8-20$.

FARIA, R.T. e W.M. KRANZ, 1982. Determinação de espaçamentos e densidades adequados para cultivares de diferentes portes. In: Anais da lạ Reunião Nacional de Pesquisa de Feijão, Goiânia, p.118-119.

FONSECA, H.; J.R. SARRUGE; J.D.P. ARZOLLA, 1974. Componentes minerais e orgânicos de algumas variedades de feijão (Phaseolus vulgaris L.). Anais da Escola Superior de Agricultura "Luiz de Queiroz", Piracicaba, 31: 509-517. 
FONTES, L.A.N.; L.J. BRAGA e F.R. GOMES, 1973. Resposta da cultura do feijão (Phaseolus vulgaris L.) à aplicação do calcário, adubo nitrogenado e fosfatado em municípios da Zona da Mata, Minas Gerais. Revista Ceres, Viçosa, 20 : $313-325$.

FRIZZONE, J.A.; F. CASSIANO SOBRINHO, M.E. SA e S. BUZETTI, 1982. Efeito da irrigação e da adubação fosfatada sobre a produção do feijão (Phaseolus vulgaris L.). In: Anais da 1ạ Reunião Nacional de Pesquisa de Feijão, Goiânia, p.169-172 .

GARRIDO, M.A.T.; J.R.C. PURCINO e C.A.S. LIMA, 1979. Efeito do déficit de água em alguns períodos do ciclo de crescimento sobre o rendimento do feijoeiro comum. Projeto Feijão, Relatório 77/78, Belo Horizonte, p.25-28.

GODOY, O.P., 1968. Adubação mineral do feijoeiro (Phaseolus vulgaris L.). Piracicaba, 64p. (Livre docência - ESALQ).

GUAZZELLI, R.J., 1980. Cultivares melhoradas e tradicionais de feijão nos Estados. Comunicado Técnico, EMBRAPA, Goiânia, n. 7, p. 1-4.

GUAZZELLI, R.J.; J.F. MENDES; G.R. BAUWIN e S.F. MILLER, 1973. Efeitos agronômicos e econômicos do calcário, nitrogênio, fósforo, potássio, enxofre e micronutrientes nos rendimentos de soja, feijão e arroz em Uberaba, Minas Gerais. Pesquisa Agropecuária Brasileira, Série Agronomia, Brasília, 8: $29-37$.

GUEDES, G.A.A. e A. JUNQUEIRA NETO, 1978. Calagem e adubação. Informe Agropecuário, Belo Horizonte, $\underline{4}(46): 21-23$. 
JUNQUEIRA NETO, A.; M.V.A. PINTO e J.F. SILVEIRA, 1982. Efeitos de fontes, doses e formas de aplicação do fósforo na produção do feijão (Phaseolus vulgaris L.). In: Anais da lạ Reunião Nacional de Pesquisa de Feijão, Goiânia, p. 190-191.

KORNELIUS, E.; L.F. SOBRAL; J.C. GOMES e E.M. RODRIGUES, 1976. Efeitos de doses de nitrogênio e fósforo na produção de feijão. In: Anais do 159 Congresso Brasileiro de Ciência do Solo, Campinas, p.203-205.

KRANZ, W.M.; O. MUZILLI; A.S. POMPEU e B. VAN RAIJ, 1976. Respostas do feijoeiro ao nitrogênio, fósforo e potássio nos principais solos do Estado do Paraná. In: Anais do 15: Congresso Brasileiro de Ciência do Solo, Campinas, p.235-238.

MAEDA, J.A.; E. ZINK e L.D'A. ALMEIDA, 1982. Teste de vigor: envelhecimento rápido em sementes de feijão. In: Anais da 1ă Reunião Nacional de Pesquisa de Feijão, Goiânia, p.336-339 .

MAGUIRRE, J.D., 1962. Speed of germination and in selection and evaluation for seedling emergence and vigour. Crop Science, Madison, $\underline{2}(2): 176-177$.

MALAVOLTA, E., 1957. Práticas de química orgânica e biológica. Piracicaba, 77p. (mimeografado)

MARCOS FILHO, J. e O.P. GODOY, 1974. Efeitos de radiação gama do ${ }^{6}{ }^{0} \mathrm{Co}$ na conservação da semente do feijoeiro (Phaseolus vulgaris L. variedade Goiano Precoce). Anais da Escola Superior de Agricultura "Luiz de Queiroz", Piracicaba, 31: $147-158$. 
MASCARENHAS, H.A.A.; S. MIYASAKA; T. IGUE; L.A. LOVADINI e B.S. FREIRE, 1967. Adubação mineral do feijoeiro. XI - Efeitos de NPK e calagem em campos cerrados do planalto paulista. Bragantia, Campinas, $\underline{26}(22): 303-316$.

MIYASAKA, S.; E.S. FREIRE; H.A.A. MASCARENHAS e T. IGUE, 1965. Adubação verde, calagem e adubação mineral do feijoeiro em solo com vegetação de "cerrado". Bragantia, Campinas, $\underline{24}$ (26) : $321-338$.

NAKAGAWA, J.; J.R. MACHADO; O. BRINHOLI; D.A.S. MARCONDES e C.A. ROSOLEM, 1978. Comportamento de cultivares de feijão (Phaseolus vulgaris L.) em são Manoel. Experimento III. Cientifica, Jaboticabal, $\underline{6}$ : 81-84.

OLIVEIRA, I.P.; H. AIDAR e J.R.P. CARVALHO, 1982a. Efeitos de níveis de fósforo, população de plantas e hábito de crescimento na cultura do feijão (Phaseolus vulgaris L.) em solo de cerrado. In: Anais da lạ Reunião Nacional de Pesquisa de Feijão, Goiânia, p.217-219.

OLIVEIRA, I.P.; J. KLUTHCOUSKI e J.R.P. CARVALHO, 1982b. Efeitos de macro e micronutrientes na cultura do feijão (Phaseolus vulgaris L.) em latossolo vermelho escuro. In: Anais da 1ạ Reunião Nacional de Pesquisa de Feijão, Goiânia, p.214-216.

PARODI, A.E.; A.J.D. OPAZO e J. MOSTIDIS, 1977. Efecto de la aplicación de fósforo sobre el rendimento biológico y contenidos de $\mathrm{N}, \mathrm{P}$ e $\mathrm{K}$ en la planta de frijol (Phaseolus vulgaris L.). Agricultura Técnica, Santiago, 37(1): 12-18. 
PONS, A.L.; B.A. BARRETO; V.A. SECCHI e V. MARTINOTTO, 1980. A cultura do feijoeiro do RS. Trigo e Soja, Porto Alegre, 48: $2-31$.

PROGNÓSTICO 81/82. São Paulo, Instituto de Economia Agrícola, $1981, \mathrm{p} .109-114$.

PURCINO, J.R.C.; T.J. CAIXETA e M.A.T. GARRIDO, 1978. Efeito da aplicação de quatro lâminas de água e três níveis de fertilizantes no rendimento do feijoeiro comum (Phaseolus vulgaris L.). II - Projeto Feijāo, relatōrio 73/75, Belo Horizonte, p. 30-34.

SĀ, M.E.; S. BUZETTI; S. MORELLO e N.D. DESIDERIO, 1982. Efeitos da densidade de plantas e da fertilização fosfatada sobre a produção do feijoeiro. In: Anais da lạ Reunião Nacional de Pesquisa de Feijão, Goiânia, p.101-103.

SANTA CECILIA, F.C.; M.A.P. RAMALHO e A.F. SOUZA, 1974. Efeitos do espaçamento de plantio na cultura do feijão. Agros, Lavras, $\underline{4}(1): 11-21$.

SANTANA e SILVA, J.J., 1982. Efeito do espaçamento e da densidade do plantio sobre a produtividade do feijoeiro. (Phaseolus vulgaris L.). In: Anais da lạ Reunião Nacional de Pesquisa de Feijão, Goiânia, p.97-100.

SARTORATO, A.; I.F. ANTUNES; J. KLUTHCOUSKI; J.A.M. ROCHA; M.G. TEIXEIRA; M. YOKOYAMA; P.M. SILVEIRA e R.J. GUAZZELLI, 1981 . Sistema de Produção para o Cultivo de Feijão no Inverno. Circular Têcnica. EMBRAPA, Goiânia, n.12, 21 p. 
SARTORI, M.R., 1971. Deterioration of bean seed and its consequences. State Mississipi College, 63p. (Thesis M.S. Mississipi State University)

SILVA, H.T. da, 1981. Caracterização morfológica, agronômica e fenológica de cultivares de feijão (Phaseolus vulgaris L.) comumente plantadas em diversas regiões do Brasil. Circular Técnica. EMBRAPA, Goiânia, n.15, 51 p.

SILVEIRA, P.M.; J.R. FONSECA e C.M. GUIMARÃES, 1981. Consumo de água pelo feijão de 3ạ época irrigado por aspersão. Comunicado Técnico. EMBRAPA, Goiânia, n.9, p.1-5.

THUNG, M.; J. ORTEGA e R. RODRIGUEZ, 1982. Respuesta Y aprovechamiento del fósforo aplicado a dos profundidades y su efecto en el rendimento del frijol (Phaseolus vulgaris L.). In: Anais da lạ Reunião Nacional de Pesquisa de Feijão, Goiânia - GO, p.205.

TOLEDO, F.F. e MARCOS FILHO, J., 1977. Manual das Sementes: Tecnollogia da Produção. São Paulo, Ed. Agronômica Ceres, $224 \mathrm{p}$.

WATT, B.K. e A.L. MERRIL, 1963. Composition of foods, raw, processed prepared. Washington, D.C., United States Department of Agriculture. Agriculture Handbook, Washington, $8,190 \mathrm{p}$.

WEBSTER, L.V. e S.T. DEXTER, 1961. Effects of physiological quality of seeds on total germination, rapidity of germination and seedling vigour. Agronomy Journal, Madison, $\underline{53}$ (5) : 297-299. 
VEIGA, A.A.; E.A. BULISANI; S. MIYASAKA; L.D'A. ALMEIDA e B. VAN RAIJ, 1977. Efeitos da incorporação ao solo de massa vegetal crotalaria juncea, da calagem e da adubação com nitrogênio e fósforo sobre a produção do feijoeiro. Produção do feijoeiro. Boletim Técnico do Instituto Agronômico, Campinas, no 48 , 18p.

VIDAL, L.S. e A. JUNQUEIRA NETO, 1982. Efeitos da densidade de plantas e de doses de fósforo sobre a produção de duas cultivares de feijão (Phaseolus vulgaris I.). In: Anais da lạ Reunião Nacional de Pesquisa de Feijão, Goiânia, p.114.

VIEIRA, C., 1968. Efeitos da densidade de plantio sobre a cultura do feijoeiro. Revista Ceres, Viçosa, 15: 44-53.

VIEIRA, C., 1978. Cultura do feijão. Viçosa, U.F.V., 146p.

VIEIRA, C.; A. BUSS; B.C.L. CARVALHO; D. BRANDES; F.F. DUQUE;

F.J.P. ZIMMERMANN; G. BALDANZI; J.G.C. COSTA; ALMEIDA, L.D'A. ; N.T. PONTE; R.J. GUAZZELLI e S. MIYASAKA, 1972. Variedades, melhoramento e genética do feijoeiro. In: Anais do 1o Simpósio Brasileiro de Feijão, Campinas, p.155-200.

VIEIRA, C. e L.A. ALMEIDA, 1965. Experimento de espaçamento de semeadura do feijão (Phaseolus vulgaris L.). Revista Ceres, Viçosa, 12: 219-228.

VIEIRA, R.F.; J. KLUTHCOUSKI; J.R. FONSECA e J.R.P. CARVALHO, 1982. Efeito do superfosfato simples e do calcário sobre o comportamento de sementes de feijão (Phaseolus vulgaris L.). In: Anais da lạ Reunião Nacional de Pesquisa de Feijão, Goiânia, p.203.204. 
103.

7. APÊNDICE 


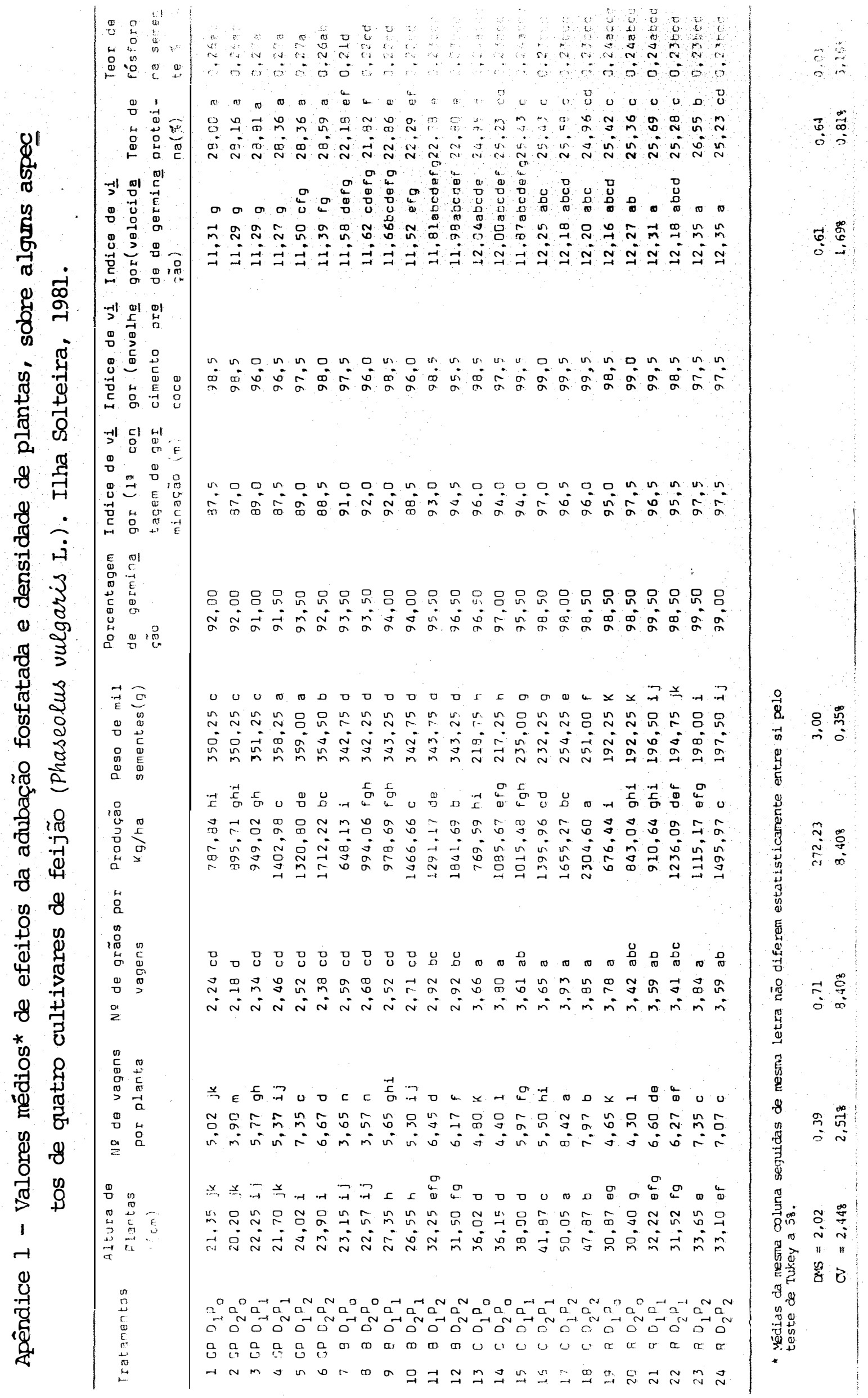

